\title{
TALE OF TWO SCHOOLS:
}

\section{A PHENOMENOLOGICAL CASE STUDY OF CULTURE IN A HIGH SCHOOL WITH AN INTERNATIONAL BACCALAUREATE PROGRAM}

\author{
A Dissertation \\ presented to \\ the Faculty of the Graduate School \\ at the University of Missouri-Columbia \\ In Partial Fulfillment \\ of the Requirements for the Degree \\ Doctor of Education \\ by \\ CALLIE NEWTON-WOODS \\ Dr. Cynthia MacGregor, Dissertation Supervisor \\ MAY, 2018
}


The undersigned, appointed by the dean of the Graduate School, have examined the dissertation entitled

\section{TALE OF TWO SCHOOLS:}

\section{A PHENOMENOLOGICAL CASE STUDY OF CULTURE IN A HIGH SCHOOL WITH AN INTERNATIONAL BACCALAUREATE PROGRAM}

presented by Callie Newton-Woods, a candidate for the degree of doctor of educational leadership and policy analysis, and hereby certify that, in their opinion, it is worthy of acceptance.

Professor Cynthia MacGregor

Professor Kim Finch

Professor Michael Hudson

Professor William Agnew 


\section{DEDICATION}

I dedicate this dissertation to my husband Zac, who not only supported me the last three years through coursework, but who also helped me to shape and create my thoughts around this subject matter. He has been a sounding board, a strong shoulder, and my motivation to keep moving forward throughout this process. This labor of love was truly created by us together and I am so thankful for his influence over my life, both professionally and personally. I look forward to many more years and milestones of growing and creating together. You're next. All Things New. Love you. 


\section{ACKNOWLEDGMENTS}

There are many people who have helped to make this possible. To all of the ELPA support staff who helped with paperwork, enrollments, and graduation, thank you. To all the ELPA professors who invested in my learning, thank you. To my cohort members and classmates who kept me sane through this process, thank you. There are many more, however, I would like to specifically thank Dr. Cynthia MacGregor, my professor at Missouri State and my academic advisor. Without her expertise, guidance, and at times humorous motivation, I certainly would not have finished this monumental task. I am thankful for both her knowledge as a scholar, but also for her leadership and application in this program. She stated the first day that as long as we did not quit, she could fix anything. She was true to her word and is truly one of a kind. I am so grateful to have worked with her throughout this process. I would also like to specifically thank my dissertation committee who gave of their time and expertise to walk me through the dissertation process as well as help finish the final product. 


\section{TABLE OF CONTENTS}

ACKNOWLEDGEMENTS .........................................................

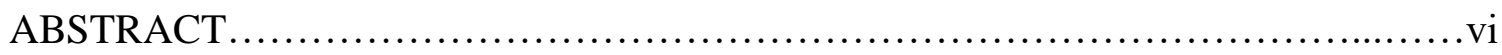

Section One

INTRODUCTION..................................................2

Background....................................................

Statement of Problem............................................4

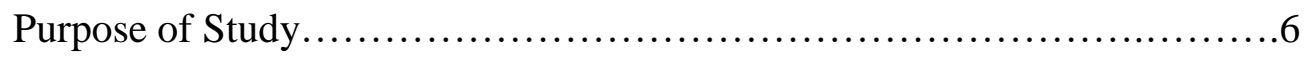

Research Questions.............................................8

Theoretical Framework...........................................8

Design of the Study................................................... 11

Limitations and Assumptions...................................... 15

Definition of Key Terms......................................... 17

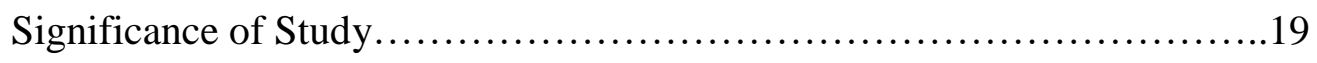

Summary ....................................................21

Section Two

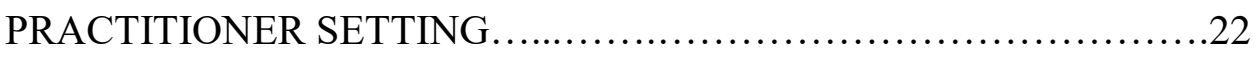

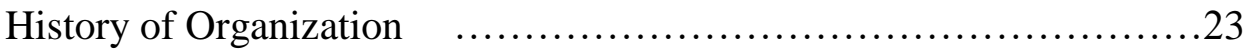

Organizational Analysis........................................29

Leadership Analysis..........................................32

Implications for Research in the Practitioner Setting...................35

Summary.................................................. 37 
Section Three

SCHOLARLY REVIEW...........................................

Organizational Culture......................................41

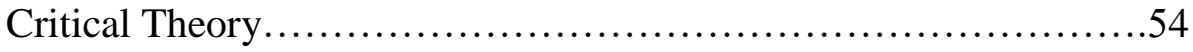

Leader Member Exchange Theory ..............................60

International Baccalaureate..................................67

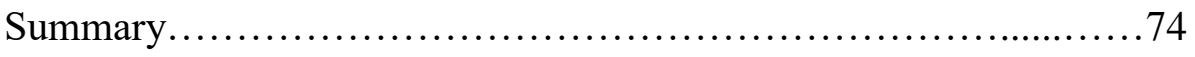

Section Four

CONTRIBUTION TO PRACTICE..............................76

Executive Summary $\ldots \ldots \ldots \ldots \ldots \ldots \ldots \ldots \ldots \ldots \ldots \ldots \ldots \ldots \ldots . \ldots . \ldots \ldots$

Presentation Slides............................................... 79

Section Five

CONTRIBUTION TO SCHOLARSHIP ............................98

Abstract.........................................................100

Introduction............................................. 101

Literature Review............................................ 103

Research Design and Analysis............................... 107

Findings....................................................... 112

Discussion................................................. 126

Implications............................................ 127

Recommendations for Practice................................128

Limitations................................................ 129

References................................................130 
Figures.

Section Six

SCHOLARLY PRACTITIONER REFLECTION.................138

Dissertation's Influence on Educational Leadership................139

Dissertation's Influence on Scholarship........................143

Summary of Leadership and Scholarship........................147

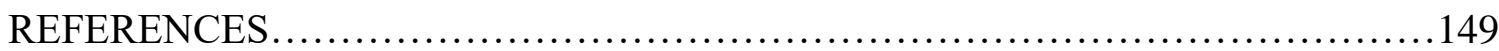

APPENDIX ........................................................... 157

VITA.................................................................... 169 
TALE OF TWO SCHOOLS:

A PHENOMENOLOGICAL CASE STUDY OF CULTURE IN A HIGH SCHOOL WITH AN INTERNATIONAL BACCALAUREATE PROGRAM

\author{
Callie Newton-Woods \\ Dr. Cynthia MacGregor, Dissertation Supervisor
}

\begin{abstract}
International Baccalaureate (IB), a highly rigorous academic and college preparatory program, has sometimes been implemented to turn around otherwise struggling school systems. Little is known about the impact on school culture from the implementation of IB in a low-achieving, high poverty school through the lens of critical theory and leader-member exchange theory. The purpose of this study is to gain teacher and student perspectives on the culture of a high school twenty years after the introduction of IB. The research questions that guided this study were as follows: Based on staff and student perceptions, what is the current culture at Central High School? What is the role of International Baccalaureate in that culture? Findings indicated that the culture of this high school was diverse, historic, superficially unified, and deeply divided. Findings further indicated that IB both encouraged diversity within the school, as well as facilitated division. Implications from this research state Central will continue to survive, and perhaps even grow, as a diverse and historic educational institution, however, the approach used towards cultural division will continue to perpetuate social, educational, and economic disparities within that school.
\end{abstract}


Section One - Introduction to Dissertation 
Culture exists in all places, whether in nations, organizations, homes, or in schools (Bolman \& Deal, 2013; Deal \& Peterson, 2016; Schein, 2005, 2010). School culture is vastly important because it dictates, at times unspoken, how things are done in an educational setting (Barth, 2002). It is imperative educational leaders become familiar with what culture is and how it can affect a school system. Understanding school culture is vital to a school's success (Deal \& Peterson, 2009, 2016; Gruenert \& Whitaker, 2015). As educational leaders, it is important that we know and learn about school culture, especially if the hope is to change it and make it better. Based on the ideas of critical theory, critical educational leaders should constantly think about school culture as well as how the school is structured.

In their book, Adult learning: Linking theory and practice, Merriam and Bierema (2014) stated critical minds "ask questions about social conditions" (p. 215). This would include culture, and even more pointed than that, school culture. In their book, School culture rewired: How to define, assess, and transform it, Gruenert and Whitaker (2015) mimicked this thought and further extended it stating "culture is both a survival mechanism and a framework for solving problems" (p. 4). Problems are seen every day in the educational world, and if culture is both how we survive and how we solve problems, extra care should be taken to learn about it. This would include questions about school culture in general and how a particular school culture came to be. Martin (2002) answered the question about why educational leaders should even bother to study culture by stating that it generates commitment and increases productivity. These things would be highly valuable in the school setting. 
According to critical theory, unequal power relations are created in every cultural setting, no matter if it is nationally, organizationally, or in a school. This difference in power will always produce the haves and the have-nots (Merriam \& Bierema, 2014). Indeed, Merriam and Tisdell (2016) stated "power dynamics are at the heart of critical research" (p. 61). This stratification has been created habitually in educational settings, school culture, and student achievement levels. Marginalized groups within the school system are no novel idea. The leader-member exchange (LMX) theory states that based on leader and follower exchanges, there is always an "in-group" and an "out-group" created within an organization, or in this case, a school setting (Northouse, 2016). Gruenert and Whitaker (2015) seconded this statement by defining culture as "patterns of behavior that distinguish us from them" (p. 6). This should communicate to leaders in the educational system that there is always a culture within the school, and often, this culture can create an "us and them" mentally, or as Northouse (2016) explained it, an "ingroup" and an "out-group."

\section{Background}

International Baccalaureate (IB), a highly rigorous academic and college preparatory program, has been implemented in the United States for many reasons. One of the reasons is to turn around otherwise struggling school systems. The IB website states "Education is an act of hope in the face of an always-uncertain future. An IB education calls forth the very best in students and educators alike" (International Baccalaureate Organization, 2017d). Studies have reported how IB can have a positive impact on schools and their culture (Duarte, 2012; Mayer, 2008; McMaster, 2015). Other sources (Bunnell 2008, 2009) have mentioned there are groups within the United States 
that are not proponents of the IB program. One researcher has even gone as far as to call it un-American and that its implementation has created a culture war (Bunnell, 2008, 2009). This begs the question, what is school culture and how does IB affect it? When the implementation of IB into schools is meshed with critical theory and leader-member exchange theory (LMX) the critical question becomes, are school leaders essentially helping to reinforce or even create these "in-groups" and "out-groups" within a school culture, or are they reinforcing a dual culture within a school intentionally?

This paper reports an investigation of such a phenomenon. In the case of Central High School, the International Baccalaureate Program was introduced and implemented in a low socio-economic status (SES) rather diverse city school that was in danger of closing, in the hopes of making some positive changes. Previous research (Bunnell, 2008, 2009; Duarte, 2012; International Baccalaureate Organization, 2017b; Mayer, 2008; McMaster; 2015) suggests implementing IB into an already established school has both positive and negative consequences on school culture.

\section{Statement of Problem}

As an educator, coach, and counselor at Central High School, I have observed a dual culture over the past nine years in many different areas, which has possibly created a problem of practice. The insider perspective I have and the bias it may create will be discussed further in the design of the study section.

What I have observed is the possible creation of an "IB" group and a "non-IB" group within Central High School with students and staff alike. The LMX theory would call this the "in-group" and the "out-group" respectively (Northouse, 2016). It seems to happen across all areas including academics, athletics, and other social groups. 
Introducing the International Baccalaureate Program into an already established school may have created a fragmented school culture, one with a seemingly positive connotation and one with a seemingly negative connotation. Through informal conversations with students and teachers, and my own observation, both in and out of the IB program, the overall feel of the school seems to be fragmented. I have heard many staff members using such language as "my kids," "IB kids," "non-IB kids," or even, "those other kids."

Demographics within the school have also changed with the introduction of IB. It is possible with this change in demographics there also might be an influence on existing culture. While evidence of positive outcomes of IB in public schools in the United States has been established, there is very little investigation on the converse or negative outcomes of the implementation of IB on school culture. What specific problems it may or may not be creating within the school has yet to be seen or studied. Because of the seemingly dual culture at Central High School, what it is like to be both a teacher and a student there is vastly different from other demographically similar schools. This research would help to address this problem in practice.

This research also helped to address the existing gap in literature. There is literature about school and organizational culture, critical theory and LMX theory, as well as the structure of IB (Bolman \& Deal, 2013; Deal \& Peterson, 2016; International Baccalaureate Organization, 2017b; Merriam \& Bierema, 2014; Northouse, 2016; Schein 2005 , 2010). However, information is lacking on how those ideas might work and mesh together. Although studies have looked at how IB affects student outcomes (International Baccalaureate Organization, 2017a), few have studied its influence on school culture, 
especially without having a biased slant toward a positive impression of IB and its influence on school systems.

A study done by Bunnell (2008) found a university in England denouncing IB as "elitist and divisive" (p. 420) but these types of studies explaining negative consequences of IB are limited. Case studies and dissertations conducting research around the implementation of the IB program found the benefits of IB far outweighed the negative aspects, if any negative aspects were named at all (Duarte, 2012; Mayer, 2008; Stillisano, Hostrop, Waxman, \& Rollins, 2011). In their article, Case studies of eight Texas schools implementing International Baccalaureate programs, Stillisano, et. al (2011) found that "although all schools identified concerns...they strongly emphasized characteristics of the IB program that they recognized as beneficial for their students" (p. 181).

This point of view is echoed in other studies. It is important to look at how IB affects school culture, not simply school achievement, and it is equally important that school leaders research the school culture with a willingness to list both positive and negative outcomes. When looking through the strategies of Colquitt and George (2011), it is essential to investigate the influence of IB on school culture in this particular school setting because it is a novel case study as well as curiosity provoking. Educational leaders still know very little about how IB affects school culture while looking through a critical lens or by using the LMX theory. This research will help to address this very specific literature gap.

\section{Purpose of Study}

The purpose of this study was to research the implementation of the International Baccalaureate program in an otherwise established school system and its influence on 
school culture. Due to the atypical nature of Central High School, studying what is happening currently with its school culture helps address a problem of practice for current school leaders. Leaders of Central High School and other similar schools should have a better understanding of what it is like to be a teacher and a student in an atypical high school running under the influence of two seemingly separate cultures. The practicality is for school leaders to have a better understanding of what is happening within their school building thus being able to facilitate and create maximum success for teachers and students alike. Habegger (2008) shared in her article, The principal's role in successful schools: Creating a positive school culture, "Yes, all the other roles and responsibilities of a school principal are important. But a positive school culture is imperative” (p. 43). Gruenert and Whitaker (2015) stated, "culture provides a school's identity and image - its brand" (p. 17). School leaders have a responsibility to their school culture and to help create a positive identity, image, and brand, where all students can be successful and have a positive educational experience.

Secondly, this study filled a gap in existing research. There are many studies around IB and even the effects of IB on schools, but most of them seem somewhat biased as they have a positive slant toward IB, a lot of them being written by IB enthusiasts, or even those working for the IB program (Duarte, 2012; International Baccalaureate Organization, 2017a; Mayer, 2008; McMaster, 2015; Stillisano et. al, 2011). However, there is a lack of unbiased research investigating the influence of IB on a school's culture. Little research exists on the effects of IB on school culture presented with both positive and negative findings, specifically using critical theory and LMX theory as a lens, and this study will address that issue. 


\section{Research Questions}

The overarching research questions that will guide this study are as follows:

1) Based on staff and student perceptions, what is the current culture at Central High School?

2) What is the role of International Baccalaureate in that culture?

\section{Theoretical Framework}

The following section will summarize the three theoretical frameworks this study will use for research. This includes organizational and school culture, critical theory, and leader member exchange theory.

\section{Organizational/School Culture}

Organizational culture can be defined as the "glue" and "stuff" that holds organizations together (Manning, 2013). Deal and Kennedy (1982) simply stated "culture is the way we do things around here" (p. 4). When looking for a more formal definition of culture, Schein (2010) defined culture as "a pattern of shared basic assumptions learned by a group as it solved its problems of external adaptation and internal integration...to be taught to new members as the correct way to perceive, think, and feel" (p. 18). There is much to be gleaned about what creates a culture, who creates a culture, and how to carry on a culture. Aspects like certain symbols, having a common language, or common goals, stories, and themes are all ways that culture can be created and carried on (Bolman \& Deal, 2013; Deal \& Kennedy, 1982; Deal \& Peterson, 2009, 2016; Gruenert \& Whitaker, 2015; Manning, 2013; Schein, 2005, 2010). All organizations have a culture and are constantly developing that culture, including culture 
within the education system. Therefore, school culture will take on much the same definition of organizational culture.

One of the earliest researchers on school culture, Willard Waller (1932) in his book, The sociology of teaching, stated this about school culture: "Schools have a culture that is definitely their own. There are, in the school, complex rituals of personal relationships, a set of folkways, mores, and irrational sanctions, a moral code based upon them" (p. 96). Current researchers have found similar insights as Waller. Deal and Peterson (2009) stated school culture is the "glue, the hope, and the faith that hold people together" and the "unofficial pattern that seems to permeate everything" (p. 5). At the same time, Schein (2010) asserted that culture is subjective and hard to define, though powerful. It is through this understanding and assumption school culture is both extremely powerful and yet difficult to describe, that school leaders should begin to investigate the implementation of IB into school systems and its influence on the culture around it.

For the purpose of this study, I will be examed common pillars of culture as cited by experts in the field. When collecting data, the following specific areas of culture were examined: (a) shared values and beliefs, (b) norms and rules, (c) symbols and artifacts, and (d) language (Bolman \& Deal, 2013; Deal \& Kennedy, 1982; Deal \& Peterson, 2009, 2016; Gruenert \& Whitaker, 2015; Manning, 2013; Schein, 2005, 2010).

\section{Critical Theory}

When looking at this investigation through the critical theory lens, researchers should begin to ask some important questions. Merriam and Bierema (2014) declared very simply that "critical theory critiques social conditions" (p. 214). When looked at in 
a deeper way, critical theory looks at everything from the unequal creation of power relations, to challenging "truths" created by dominate groups, to seeking to eliminate oppression of marginalized societal groups (Merriam \& Bierema, 2014). Schools are a microcosm of larger society, meaning they too have dominant and non-dominant groups as well as marginalized students. Looking at the implementation of IB and its influence on school culture through the critical theory lens would investigate how these specific areas have been affected.

\section{Leader Member Exchange Theory}

Similarly, when pursuing this investigation through the lens of LMX theory, "ingroups" and "out-groups" are defined (Northouse, 2016). According to LMX theory, leadership will give special attention and treatment to in-groups as well as more of their time and support (Northouse, 2016). When researching school culture and the implementation of IB through the LMX theory lens, this study would investigate who the "in-groups" and "out-groups" are in Central High School.

When thinking through how these facets mesh together, school culture, IB, critical theory, and LMX theory, it is important to remember that people both create and are created by culture. Rogoff (2003) asserted culture does not just influence people, but rather people and culture are connected. While people are contributing to cultural ideas, culture is also contributing and modifying people. Similarly, Bolman and Deal (2013) stated "culture is both a product and a process" (p. 263). As people, we are both affected by and can affect the culture around us. This specific case study looks deeper at the blending of these frameworks and how they interact, choosing to investigate specifically 
the implementation of IB within an already existing school and its influence on that school culture.

\section{Design of the Study}

The following section will discuss the setting of this study, as well as participants in the study, data collection tools, data analysis techniques, and limitations such as researcher positionality.

\section{Setting}

Central High School was built in 1893 and is located in Springfield, Missouri. It is considered a historic landmark for Springfield, as it was the first high school constructed in the city. At one point in the 1950s, Central was the largest high school in the state with a student population of 3,500 students. Historically, Central is one of the first schools to become integrated. In 1954, Central opened its doors to students of color. The school administration now boasts of graduate Linda Brown, namesake to the famous civil rights case, "Brown vs. The Topeka Board of Education." Central remains the most racially and socio-economically diverse school in Springfield (Missouri DESE, 2017).

Even with this rich history, Central High School has endured some rough times. The school has been nearly closed twice. The last time this threat was a real possibility was in 1995 and enrollment was at a new low. School board members were considering tearing the school down or selling it to the neighboring college, Drury University. The introduction of the International Baccalaureate Program, or IB, happened in 1996 and this action transformed Central into one of the premiere high schools and college preparatory programs in the nation (Central High School, 2017a). It is consistently in the top tier of nationally ranked high schools and is often recognized as a Gold Medal school by U.S. 
News and World Reports (2012). With enrollment now nearing 1800 students, Central is one of the largest high schools in Springfield. It boasts of students applying and being accepted to colleges around the country, multiple National Merit finalists and winners each year, as well as the top ACT scores in the district on a yearly basis (Central High School, 2017b). This is a far cry from the Central that was slated to be closed 23 years prior. The current Central High School is different than previous years; it has a different student demographic and a seemingly different school culture. Within this investigation, the current culture at Central High School will be studied as well as the role of IB in that culture.

\section{Participants}

The participants of this case study were teachers, graduated students, and staff at Central High School spilt into very specific groups. The groups were split to those involved in IB, those considered non-IB, and those who were a participant in both the IB and the non-IB programs.

Teachers. All 84 teachers working in the building were participants and were contacted to take the online survey. This sample is both comprehensive and purposeful in order to help the researcher understand both the problem and research question (Creswell, 2016; Fink, 2013). Sampling all teachers for the survey gives the greatest chance of many responses for data saturation. The population pool includes teachers from every subject area, grades 9-12, male and female, and with varying years of experience.

Students. Student participants include 10 IB students, 10 non-IB students, and 10 students who have taken both IB and non-IB classes. These 30 students were asked to 
participate in the same online survey provided to the teachers at Central High School, with the questions geared towards the students. Choosing the 30 students to participate in the survey process is a convenient sample (Creswell, 2016; Fink, 2013). These students were recent graduates of Central High School with a graduation date of either 2016 or 2017.

\section{Data Collection Tools}

Data for this case study was collected through several different means. By investigating different data sources, I gained a more complete portrait of school culture at Central High School and the role implementation of IB has played in that school culture. Utilizing several different data sources also allowed me to gain "data triangulation" as well as "data saturation" thus helping to support the phenomenological case study findings (Creswell, 2014; Merriam \& Tisdell, 2016; Yin, 2014). All data collection tools such as survey items, observation guides, and artifact collection were guided by the case study research as presented by leaders in the area (Creswell, 2014; Fink, 2013; Merriam \& Tisdell, 2016; Seidman, 2013; Yin, 2014). The data was examined through the critical theory lens (Merriam \& Bierema, 2014) as well as LMX theory (Northouse, 2016). The "how" and "why" questions were asked as well as questions that "require an in-depth description of some social phenomenon" (Yin, 2014, p. 4).

Online Survey. Online qualitative surveys using open ended questions through Qualtrics were sent to teachers and students participating in the case study. Specifically, the survey was sent to all teachers at Central High School and the 30 student graduates from Central High School. Qualitative survey questions can be found in Appendix A and B. 
Artifacts and Documentation. Artifacts and school documentation such as year books, newspaper clippings, twitter accounts, school newspapers, and magazines were used. This will also include archival data such as school demographics. The artifact tool can be seen in Appendix C.

Observations. Classroom observations were done in both IB and non-IB classes as well as participant observations through my own work in classrooms, hallways, meetings, lunchrooms, and sporting events. The observation guide can be seen in Appendix D.

\section{Data Analysis}

In this phenomenological case study, data was analyzed through constant comparison of artifacts, survey answers, and classroom observation findings. All data sources went through a series of coding. Coding, as explained by Creswell (2016), "is inductive, working from the raw data up to the codes" (p. 154). Merriam and Tisdell (2016) discussed the three phases of coding that happen in grounded theory as open, axial, and selective. Open coding was used to examine the research data looking for emerging patterns (Creswell, 2016; Merriam \& Tisdell, 2016; Yin, 2016). Once patterns are detected in the open coding, axial coding took place to make meaning of the data patterns and be sorted into more meaningful categories or themes. From there, analytical coding happened as interpretations of meaning and reflection are done (Merriam \& Tisdell, 2016). Coding all three forms of data in this way, surveys, artifacts, and the classroom and participant observations, created the "data triangulation" researchers look for to create data saturation, therefore supporting the phenomenological case study findings (Creswell, 2014; Merriam \& Tisdell, 2016; Yin, 2014). 


\section{Limitations and Assumptions}

As the researcher, I acknowledge a possible bias within the research due to the insider perspective. Many safeguards were put in place to help combat this possible limitation. Secondarily, the case study design of this research limits the transferability of the findings. As the researcher, I also acknowledge the uniqueness of the case study, but also believes the findings add to the value of the discussion around IB and school culture.

\section{Researcher Positionality and Research Ethics}

I have spent the last nine years at Central High School serving in many capacities. I have been an educator, a coach, and now a counselor who has been able to work with many different students across all grade levels and programs in the school, as well as work with staff members across grade level, curricular area, and IB and non-IB classes. This insider perspective must be discussed as a possible barrier to the information and data collected, as well as a possible benefit to the information and data collected. The biggest benefit of being an insider in this research project is the access I have to the organization. I am able to easily communicate with students and staff at Central. Secondly, I have easy access to the artifact data that will be collected for this study. Being a part of the organization I am researching allows me to collect items or perspectives that might not be collected otherwise.

Conversely, being an insider within this research project also brings with it some barriers. As an insider, I need to be aware of any bias that I am carrying towards the research as well as put check points in place to help combat the bias. Seidman (2013) in Interviewing as qualitative research: A guide for researchers in education and the social sciences, as well as Merriam and Tisdell (2016) and Creswell (2014) outlined the perils 
of collecting data as an insider. According to Merriam and Tisdell (2016), I would be considered an insider to the participants in the research. As the researcher in this study, I will be taking on the role of participant as observer (Creswell, 2014; Merriam \& Tisdell, 2016). Merriam and Tisdell (2016) defined this position as “the researcher's observer activities, which are known to the group, are subordinate to the researcher's role as participant" (p. 144).

To combat the bias and make the study more trustworthy, certain safeguards have been put in place. In order to increase the credibility of the findings, the following techniques will be used. One, data triangulation with four different data sources will be utilized (Creswell, 2014; Merriam \& Tisdell, 2016; Yin, 2014). As defined by Yin (2014), triangulation is "the convergence of data collected from different sources to determine the consistency of a finding" (p. 241). Two, researcher positionality and bias will be clearly defined and discussed throughout the research (Creswell, 2014; Merriam \& Tisdell, 2016). This type of clarification "creates an open and honest narrative" (Creswell, 2014, p. 202). Three, an audit trail will be utilized. In a qualitative study, the audit trail "describes in detail how data were collected, how categories were derived, and how decisions were made throughout the inquiry" (Merriam \& Tisdell, 2016, p. 252). Four, a peer debriefing and expert review will be used to enhance the accuracy of the account and data collected (Creswell, 2014; Merriam \& Tisdell, 2016). Lastly, using a rich, thick description as well as placing actual quotes within the study will increase the validity and transferability of the research (Creswell, 2014; Merriam \& Tisdell, 2016). Having all four of these safeguards in place will help with the study's reliability, as well as its transferability. 
According to Horner and Minifie (2011) in the article, Research Ethics I: Responsible Conduct of Research (RCR) - Historical and Contemporary Issues Pertaining to Human and Animal Experimentation, there is a great need for research ethics. They asserted researchers "have obligations to protect participants' dignity as well as to maximize the benefits and minimize the harms associated with every investigation" (p. 316). The American Educational Research Association (AERA) has also put forth a code of ethics for researchers with five main principles; (a) professional competence, (b) integrity, (c) professional, scientific, and scholarly responsibility, (d) respect for people's rights dignity and diversity, and (e) social responsibility (AERA Council, 2011). These are all areas that I deem important both personally and professionally when conducting research and applying it.

\section{Definition of Key Terms}

\section{Critical Theory}

Critical theory examines and critiques social conditions by challenging "truths" set by dominant social groups. It also seeks to examine power relations created within society while helping to emancipate marginalized people groups from dominant powers and eliminate the oppression of these people groups (Merriam \& Bierema, 2014).

\section{Culture/School Culture}

Culture is defined as a pattern of shared basic assumptions learned by a group as it solved its problems of external adaptation and internal integration (Schein, 2010). It teaches new members the correct way to perceive, think, and feel. These are the unofficial patterns that seem to permeate everything including the way people act, how they dress, what they talk about or consider taboo, whether they seek out colleagues or 
isolate themselves, whether they work together, and how teachers feel about their work and their students (Schein, 2010).

\section{International Baccalaureate/International Baccalaureate Organization (IB/IBO)}

These letters are used to denote International Baccalaureate or International Baccalaureate Organization. The term IB is utilized in this research because it is used more often in the United States (International Baccalaureate Organization, 2017a).

\section{International Baccalaureate Career Pathway (IBCP)}

IBCP, or International Baccalaureate Career Pathway, is a specific branch of IB, often called CP. IBCP refers to the last two years in secondary education; in the US this is grades 11 and 12. This specific program in IB requires students to test in at least two subject areas, choose a career pathway to take specific classes in, and complete hours within creativity, service, or action. IBCP offers a certificate of completion for this program (International Baccalaureate Organization, 2017g).

\section{International Baccalaureate Diploma Program (IBDP)}

IBDP, or International Baccalaureate Diploma Program, is a specific branch often called DP. This program refers to the last two years in secondary education; in the US, this is grades 11 and 12. This specific IB program requires students to test in six subject areas as well as complete an extended essay and hours in creativity, action, and service. IBDP offers an IB diploma when students have completed all necessary components (International Baccalaureate Organization, 2017g). 


\section{Leader}

For the purpose of this study, a leader will be defined as any person who has others following them. This could be any of the participants within the study, including administrative staff, teachers, and students.

\section{Leader Member Exchange}

LMX, or Leader-Member Exchange, is a leadership theory that suggests leaders do not treat all of their followers the same. This theory states leaders create "in-groups" and “out-groups" with their followers (Northouse, 2016).

\section{Marginalized students}

Marginalization has to do with positions of power and oppression towards nondominant individuals or groups of people by those who are in a privileged group. Within education, marginalized students are those who, either by low socioeconomic status, race, religion, or any other indicator, are not considered when decisions on educational needs are made, or are seen as unimportant, or an after-thought (Merriam \& Bierema, 2014).

\section{Significance of Study}

Researching the influence of the IB Program on school culture is a worthwhile and significant study with its rapid growth and expansion in the United States. Through this case study, educational leaders can glean new perspectives and gain a deeper understanding of the implementation of an IB Program in a low socio-economic status (SES), diverse, public high school and its influence on school culture. This includes perspectives on how IB affects school culture as looked at through the lens of critical theory and LMX theory. Research from this study will give needed information and perspectives on school culture to educational leaders who are in school buildings similar 
to Central High School who have implemented an IB Program. For educational leaders, having a pulse on the culture in a particular school building is imperative (Deal \& Peterson, 2016; Gruenert \& Whitaker, 2015; Habegger, 2008). According to Deal and Peterson (2016), “culture affects all aspects of a school" (p. 14). This would include everything from effectiveness, student achievement, productivity, collegiality, and motivation. If culture has this large of an impact on our schools from top to bottom, then as educational leaders we should be aware of how implementing a new program into a school, such as IB, affects that culture.

Specifically, this study could make a significant difference at the institution being researched. Leaders within Central High School could utilize findings within this study in an effort to solidify the seemingly dual culture of IB and non-IB, into one unifying culture. Taking the time to listen to student and staff perspectives on the current culture of Central, both IB and non-IB alike, could create an avenue to address issues within the building. This research could help to increase the benefits of the IB Program within the building as well as decrease the possible negative consequences. It is also possible this research could initiate much needed conversations among school administration and the school's teachers and students (IB and non-IB) in order to open lines of communication and increase understanding.

This study will also make contributions to the existing literature gap surrounding the implementation of IB in an already existing school and how it affects school culture. As mentioned before, this study will report all findings, both positive and negative, that may or may not be found in this particular school setting in relation to the implementation of IB and its influence on school culture. 


\section{Summary}

Culture, or "the way we do things around here" (Deal \& Kennedy, 1982, p. 4) is a part of every organization, school, and group of people. It is woven throughout the fabric of the day and becomes so ingrained in what people do and do not do, they stop noticing it. Each school has its own culture that can vary from classroom to classroom. School culture can affect every aspect of the school building, from student achievement to staff

morale and collegiality (Deal \& Peterson, 2016). Often introducing a new program into a school building can yield both positive and negative consequences when dealing with school culture.

Based on the ideas of organizational culture and by utilizing a critical framework (Merriam \& Bierema, 2014) and the Leader Member Exchange Theory as sited by Northouse (2016), this study will research the implementation of the International Baccalaureate program at Central High School and its influence on the school culture. IB is a highly rigorous, college preparatory program focusing on student academic achievement. The IB Program was introduced to Central High School in the hopes of helping enrollment numbers and turn around what seemed to be a struggling school building. While much research has been done surrounding the effects of IB in schools, few are related to the influence of IB on school culture, and even fewer list both positive and negative consequences.

Through personal observation, the IB Program has seemingly created two different cultures within Central High School. This study will investigate teacher and student perceptions of the current culture at Central High School. This includes what it means to be both "IB" and "non-IB". 
Section Two-Practitioner Setting for the Study 
Built in 1893, Central High School is the oldest high school in Springfield, Missouri, and has a rich history. IB is a program that has seen tremendous growth internationally since its inception in the early 1970s and continues to grow and flourish in the United States. The IBDP Program at Central is one of the most established in the state. To begin to understand the culture at Central High School, it is important to look at the history of Central High School, the history of the IB Program, and the history of how these two organizations merged and came together in 1996. The following section will give a brief history of Central and the IB Program, as well as a snapshot of how these two organizations have meshed together. This will include an organizational and leadership analysis of the two organizations, along with implications of this research for practitioners at Central High School, both inside and outside of the IB Program.

\section{History of Organization}

Central High School was in operation a little over 100 years prior to the introduction of IB. The following section will give a brief history of Central High School before IB, a brief history of the IB Program outside of Central High School, and lastly a picture of how these two organizations came together in 1996. This will include current statistics and demographics of Central High School.

\section{Overview of Central High School}

In 1867 Springfield began to move forward in its quest for a free education. A building was rented to teach a high school class of 68 students. In 1872, the first class from Springfield graduated with two members. By 1893, the population in Springfield grew rapidly and there was a need for a school building. Construction of Central High School, then called Springfield Senior High, began during this time and cost the city a 
little over $\$ 100,000$. The building was dedicated in January of 1894 and housed 76 students. Throughout the years more features were added on to the building of Springfield Senior High including a gymnasium, science labs, a fine arts building, and a stadium. As the population of Springfield continued to grow, the need for more high schools in the district became necessary, so Springfield Senior High school was renamed Central high school in 1956 with the addition of a second high school in Springfield. Between the years of 1956 and 1971, Springfield built four more high schools for a total of five to accommodate its quick surge in population (Central High School, 2017a).

In the 1950s, the enrollment at Central High School was around 3,500 students. By 1971, with the introduction of the fifth and final high school in Springfield, Central's enrollment numbers were no longer what they once were. Throughout the next 20 years, Central's enrollment continued to dwindle due to urban sprawl as families moved south in Springfield. By the early 1990s, Central was considered a dying school with little community support, and even with its rich history, the school had been nearly closed twice. The last time this threat was a real possibility was in 1995 when enrollment numbers were at a new low. School board members were considering tearing the school down or selling it to the neighboring college, Drury University. The introduction of the International Baccalaureate Program, or IB, happened in 1996. This has turned Central around to be one of the premiere high schools and college preparatory programs in the nation and has helped to raise enrollment numbers back to the second largest high school in Springfield at just over 1,700 students (Central High School, 2017a). Because of the IBDP Program, Central has high numbers of students gaining acceptance to highly 
selective universities and college, as well as many National Merit Scholars, and some of the highest ACT scores in the district.

\section{Overview of International Baccalaureate}

After World War II there was a need for an international, consistent, and unified curriculum to be provided for children of diplomats, military, and international business men (Connor, 2008; Mathews \& Hill, 2005). The IBDP was the first program established in 1968 "to provide a challenging and comprehensive education that would enable students to understand and manage the complexities of our world and provide them with skills and attitudes for taking responsible action for the future" (International Baccalaureate Organization, 2017d, p. 1). The mission and values of IB center around rigorous academics and assessment, international mindedness, and life-long learning. As of March 2017, there are 6,068 IB Programs worldwide across 4,655 schools; $60 \%$ of these schools are in the Americas, with 1808 in the United States alone (International Baccalaureate Organization, 2017b). IB continues to gain popularity in the US as it has more IB schools than any other nation.

IB has grown rapidly in the last thirty years and has moved from international schools to the United States, including public schools (Bunnell, 2009). This program has been implemented in the United States for many reasons, but one of those seems to be to try to turn otherwise struggling school systems around. According to Mayer (2008), most recently, schools that serve socioeconomically disadvantaged students have begun to implement the IB Program as a type of reform. The article goes on to state there is little evidence to justify this kind of reform to help academic achievement in students of color and low SES (Mayer, 2008). 


\section{Central and IB Come Together}

International Baccalaureate was implemented into Central High School in 1996. It was the fourth school in the state of Missouri to implement the program. As a result, student enrollment began to flourish. Previous to the introduction of IB in 1995, enrollment at Central was at 998 students. Enrollment numbers have climbed over the last twenty-two years, with the current enrollment for the 2017-2018 school year being 1727 students (Missouri DESE, 2017). The first graduating class for the IBDP Program happened in 2000. There were 29 students in the IBDP Program at that time, 9 of them earning IB diplomas at graduation. In 2016, there were 197 students involved in the IBDP program at Central High School, 41 of them earning full IB diplomas. IB enrollment has increased by more than 60\% since 2000 (Central High School, 2017c).

Currently, there is an application process in order to be a part of the IBDP Program at Central High School. This is something students apply for at the end of their 8th grade year to prepare for their entrance as freshman. The application considers the student's GPA in middle school, as well as attendance, discipline, teacher recommendations, and student writing. There is a team of 4 to 5 Central staff that look through student applications for acceptance. Students accepted take a full honors load during their 9th and 10th grades years to prepare them for the rigor of IB diploma classes during their 11th and 12th grades years. Students and parents also must sign a contract stating as IBDP students they will follow the guidelines for the program with the understanding that they could be dropped from the program if they do not maintain their academic integrity.

Previous to the implementation of IB in 1995, the student demographics at Central High School looked much different than they do today in 2018. Enrollment was down, 
but there were also differences in student numbers. In 1995, the demographics for Central High School were as follows: (a) 32.5\% of students were on free and reduced lunch, (b) $82.67 \%$ of the student population was White, (c) $12 \%$ of the student population was Black, (d) $2 \%$ of the student population was Hispanic, and (e) there were no student numbers reported for Asian, Pacific Islander, Indian, and English Language Learner (ELL) student populations (Missouri DESE, 2017).

After the implementation of IB twenty-two years ago, student demographics at Central High School have changed somewhat. Besides enrollment almost doubling to 1727, there were other noticeable differences. For the 2017-2018 school year, the school's student demographics are as follows: (a) 50.78\% of students are on free and reduced lunch, (b) $70.69 \%$ of the student population is White, (c) $12.83 \%$ of the student population is Black, (d) $7.02 \%$ of the student population is Hispanic, (e) $7.66 \%$ of the student population is Asian, (f) $.87 \%$ of the student population is Pacific Islander, (g) $.93 \%$ of the student population is Indian, and (h) $9.34 \%$ of the student population are ELL (Missouri DESE, 2017).

The biggest noticeable changes for Central High School when referring to student demographics is its diversity. The percentage of White students has dropped significantly while the number of other student groups including ELL students and those students on free and reduced lunch have increased. It may be possible that the introduction of IB has had some impact on these differences in demographics.

\section{Current IB and Non-IB Demographics}

Demographically, the totals for the IB Program at Central are very different from the rest of the school. For the 2017-2018 school year, there are 427 students participating 
in the IB Program in some way. This includes students grades 9-12 who are involved in the full diploma program, the career program, certificate courses, or are in pre-diploma classes. This is roughly $25 \%$ of Central's total student population involved in the IB program at Central in some way. For the 2017-2018 school year, the IB Program student demographics at Central High School are as follows: (a) $18.3 \%$ of IB students are on free and reduced lunch, (b) $79.8 \%$ of the IB student population is White, (c) $2 \%$ of the IB student population is Black, (d) $2.8 \%$ of the IB student population is Hispanic, (e) $11.4 \%$ of the IB student population is Asian, (f) .2\% of the IB student population is Pacific Islander, and (g) $1.1 \%$ of the IB student population is America Indian.

There is some discrepancy and differences between the whole school demographics and the IB student population demographics. Central High School as a whole has almost $51 \%$ of their students on free and reduced lunch, while only $18 \%$ of the students participating in IB are on free and reduced lunch. Only $70 \%$ of the total school population at Central is white, while almost $80 \%$ of the IB student population is white. Lastly, the second highest percentage of students at Central are racially classified as black, sitting at almost $13 \%$. However, black students only make up $2 \%$ of the IB student population. These discrepancies may be evidence of diversity happening outside of the IB program at Central, but not necessarily inside of the IB Program at Central.

It is evident with the introduction of the IB Program at Central many positive improvements have happened over the last twenty-two years. Enrollment at Central has increased as well as the number of students attending four-year colleges and earning scholarships. Central also continues to be the most diverse high school in Springfield, 
Missouri. Based on demographics, however, it is possible this diversity may exist outside of the IB Program and the students this program brings to Central High School.

\section{Organizational Analysis}

Presently, Central High School along with the IB Organization have a clearly defined structure on paper. According to Bolman and Deal (2013), the structural frame is about having clear guidelines to follow. "Clear, well-understood goals, roles, and relationships and adequate coordination are essential" (p. 44). Central has done a great job of stating on paper what the IB Program is about and what it hopes to accomplish. These summaries and mission statements can be found in multiple places, including through social media and on Central's website. There are clearly defined roles for all the IB Programs at Central, as well as how those programs fit into the mission statement of the school. The Central High School mission states: "Central High School is dedicated to excellence in teaching and learning for all by inspiring students to become independent thinkers and lifelong learners who are prepared to be active participants in a global society" (Central High School, 2017b). The Central website also states that "as an International Baccalaureate World School, Central High School's mission and vision are aligned IBO’s mission statement" (Central High School, 2017b). It is clear Central leadership spent time making sure their mission statements align, as well as creating the structure of how they have classes and teachers set up.

There are very clear goals and objectives, created both by IB and by Central leadership, and the building as a whole has tried to make sure these goals and objectives line up with each other. Within the 2017-2018 Central Staff Handbook of Policies and Procedures, there is a section that explains all three IB programs housed at Central, 
including the IB Diploma Program, the IB Career Program, and the MYP program. Within the handbook, the leaders of these three programs are listed as well as their duties. Some of these duties include overseeing the totality of the program, budgeting for the program, providing training for the program, and helping to recruit students and grow the programs individually. The purpose of all three programs is clear as well as how they relate to the overall mission statement of the school. It is also clear on paper what the chain of command is and who someone would go to with specific questions or concerns.

However, Bolman and Deal (2013) stated "there is no such thing as an ideal structure" (p. 60). Structure can be both good and bad, depending on what the purpose of the structure is. This is true of Central as well. The job duties and the structure of IB are clear and set up well, but there are areas for improvement within the political frame and human resource frame. Bolman and Deal (2013) describe the challenge in finding balance with an organization's structure so it is not too loose or too tight but still held together well. Finding the balance can be hard and the critical challenge is "how to hold an organization together without holding it back" (p. 72).

According to Bolman and Deal (2013), "the human resource frame centers on what organizations and people do to and for one another...focusing on the fit between human needs and organizational requirements" (p. 113). Within the human resource frame, both the person and the organization benefit when the fit is good, and both entities can be harmed if the fit is not good. Depending on who you speak with at Central, some staff are a good fit within the Central/IB structure and some are not. While it is clear at Central what job duties are, often times there is a disconnect between teachers and other staff about what is expected of them and how their contributions to the building are 
valued. In any organization, according to Bolman and Deal (2013) staff who feel valued tend to stay, and those that do not find other ways to cope with the situation. Bolman and Deal (2013) stated an employee who is struggling within an organization will choose one of four different options when reacting: (a) they quit the job, (b) they stay on the job, but shut down mentally, (c) they resist what the organization is trying to do, and (d) they try to climb the hierarchy to better jobs. I have seen all of these options taken by some staff at Central. According to the human resource frame, the question will always remain about staying lean and mean to accomplish goals or whether to invest in people within the organization. Depending on who you speak with at Central, it is clear that some of them feel invested in and some of them do not. Bolman and Deal (2013) stated in order to keep employees in an organization they need to be rewarded, invested in, and empowered.

The political frame is about power and the distribution of resources. Bolman and Deal (2013) proposed the most important decisions within an organization "involve allocating scare resources - deciding who gets what...scare resources and enduring differences put conflict at the center of day-to-day dynamics and make power the most important asset" (pp. 188-189). Within the building at Central, there is always the question from year to year of which staff member will get to teach what classes. The staff generally want to teach the IB or honors level classes because the better students are thought to be taking these classes. The perception within the building seems to be the IB teachers and students get more resources, and according to Bolman and Deal, this also means they have more power within the building. The competition this has created between both teachers and students can be seen on a day to day basis. Teachers are 
competing to teach IB classes while students are competing to stay in those classes. Power is an important commodity. Bolman and Deal (2013) contended "power in organizations is basically the capacity to make things happen...the potential ability to influence behavior, to change the course of events" (p. 190). This is something that is actively vied for within this building. The voices engaged in certain decision-making tables can be considered the privileged majority according to Johnson (2006). It is important that within the organization there is diversity in all areas, including culture, gender, status, and for Central this would include IB and non-IB voices.

When looking at Central through these three frames, it is evident CHS has a solid structure set up on paper, with clear leadership roles and goals listed. However, at times that structure could work better due to human resource issues as well as power plays within the school building. It seems at times the structure of Central High School and all of the wonderful programs that is houses overshadows other needs in the building such as addressing certain human resource issues as well as the dispersion of resources and who in the building is holding all the power.

\section{Leadership Analysis}

The leadership at Central High School is structured much like any other high school in the Springfield district. There is one building principal who is in her third year in this role. The building has three assistant principals underneath the head principal, all with different duties and over different parts of the student alphabet. There is also a Coordinator of Site Interventions that acts much like an assistant principal. In addition to the group of administrators, there is a number of people that make up the leadership team. This includes teacher department heads, the IBDP coordinator, the IBCP coordinator, and 
the MYP coordinator. This team meets monthly to discuss any pertinent issues that are dispersed to the rest of the staff. Besides the administration and leadership team, there is also a professional development team that meets every Friday morning around the topic of the IB Program and its presence at Central. The professional development team that works on the IB Program and all its branches at Central is made up of 5 counselors including the IBDP and IBCP counselor, 2 IB teachers, the IB diploma program coordinator, the IB Career Program coordinator, and the IB Middle Years Program coordinator. This team makes decisions surrounding the growth and development of the entire IB Program at Central High School.

The leadership style of the administration team as a whole is a skills based approach. According to Northouse (2016), this is a leader-centered approach that emphasizes skills and abilities that can be developed. The leader's effectiveness in this approach "depends on the leader's ability to solve complex organizational problems" (Northouse, 2016, p. 43). This seems to fit the overall style of the leadership team at Central.

There are several different trains of thought when looking at the skills approach to leadership. Within this approach, skills are defined as something leaders can accomplish, and all leaders have different skill traits to bring to the table. This describes Central's leadership team as each leader has different skill sets attached to a very specific job within the building. Leadership duties have been divided based on skills each one possesses. Based on Katz's three-skill approach, some of the leaders have technical skills, some have human skills, and some have conceptual skills. This creates a wellrounded leadership team. As explained by Northouse (2016), “although each leader's 
personal attributes affect his or her skills, it is the leader's skills themselves that are most important in addressing organizational problems" (p. 57). This is a very telling explanation of how leadership is set up at Central High School.

The principal is in her third year as the lead administrator at Central, but she has been in education for the past 18 years. She spent 5 years as a teacher, 10 years as an assistant principal at Central, and is in now in her current position of leadership as head principal at Central. She is familiar with the school and its staff, as well as the overall culture of Central. She has a strong historical tie to the building as she is also an alumna. Another observation worth noting for Central High School, she is only the second female principal out of nineteen total in the school's 125-year history.

The second leadership framework presented in this section is gender leadership theory. Gender leadership theory is explained by Northouse (2016) as scholars simply asking a question: "Can women lead?" (p. 397). The fact this question is asked explains the need for gender leadership theory. Based on an Implicit Association Test built to explore the gender stereotypes associated with women in leadership, it is clear that many people still do not see women in leadership as being a viable option. Northouse (2016) asserted bias surrounds women in leadership because leadership qualities are generally associated with a "masculine" mindset. Things like strength, directness, and toughness or grit are used to describe men in leadership. This means when a woman displays these characteristics she is seen as "manly." According to Northouse (2016), women's underrepresentation in higher level leadership positions is often explained in three different ways: (a) human capital differences, meaning there is a pipeline problem where women's education, work experience, and developmental 
opportunities can get in the way of leadership positions, (b) gender differences, meaning style and effectiveness, and (c) prejudice, meaning gender stereotypes and biases. Based on these three positions, the question is not whether women can lead, but how they are received when they do. Northouse (2016) explained that prejudices such as these "explain less favorable attitudes toward female leaders, greater difficulty for women to attain leadership roles, and greater difficulty for women to be viewed as effective in these roles" (p. 405). These are some specific issues that the staff at Central has had to work through as they get more comfortable with their female leader.

There are many different types of leadership frames that could be utilized within this study, but Central's team leads individually in specific areas based on their own leadership traits, making the trait theory a good starting point from framing. For Central, this is also the first time in many years to have a female leader and working through nuances that have come with this difference in leadership are evident.

\section{Implications for Research in the Practitioner Setting}

The IB Program has obviously had positive impacts on the school and will continue to do so. With this program, enrollment has increased as well created a better academic reputation. Central is now the high school students want to attend in Springfield, especially if they are competitive academically and are looking for an edge as a college student. It is possible research about Central High School in the area of IB and culture will also produce more positive outcomes. It is also possible that some negative outcomes or areas that could be improved might come to light. In the past, Central has always been open to review. 
With the ever changing and evolving landscape of Central and the IB Program, there needs to be periodic review. There is a verification committee from the IB organization that comes to Central for an evaluation of the program every five years. The evaluation is a good thing, but still lacking in the fact it is only for the IB Program specifically, not the school as a whole. It also is lacking because it only focuses on the success or non-successes of the IB Program, instead of looking at the school as a whole entity. How the IB Program has altered the school culture and how non-IB students and staff feel about the program and what it has created at Central have not been researched. Marginalized students and staff are not a current focus of these program evaluations, nor have they ever been. It is quite possible that when asking different voices, new information about the program and how it is set up might come to light. Similarly, the culture at Central High School as related to the IB Program has never been studied. The IB Program here is now twenty-two years old and well established within the building and community. This would be a good time to evaluate how the implementation of the IB Program has affected the school culture as a whole.

Information about current culture and its possible change would be valuable to the leadership within the building for many reasons. One, as a leader it is important to have a feel or a pulse for the culture in the building. If there is a group of students or teachers that do not feel connected or feel marginalized due to a program within the building, the leader should be aware. Secondly, if leaders within the IB Program want to increase access to include more students, then leaders need to hear from those students. This would be an opportunity for Central High School to collect data from IB and non-IB students and staff, as well as create resources that would increase access and opportunity 
for students that had none. As an established IB Program with many positive attributes, this research might be the beginning of a push to consider the negative impact IB may have had on Central High School and how that negative impact might be addressed. Making an intentional decision to pursue diverse students for this program might be a good place to start.

\section{Summary for Practitioner Setting}

The 125-year history as well as the positive impact of IB speaks for itself when researching Central High School. To progress from the oldest school in the district that has almost been closed twice, to a high school with one of the premier IBDP Programs in the state is quite an accomplishment. However, there may be room still to grow as there has not been adequate research on how the implementation of the IB Program has affected the school culture or how it has affected marginalized or underrepresented student populations.

Structurally, the IB Program has a clear goal and mission that matches the overall goal and mission of Central High School. There are detailed descriptions as to the purpose of IB as a whole, as well as all three of the programs housed at Central. This includes IBDP, IBCP, and the MYP Program. Additionally, the leaders and the coordinators of this program have clear and detailed job descriptions.

Politically there is a lot of competition and vying for positions within the IB program, with both students and teachers. Most teachers in the building would consider teaching IB classes as a sign of seniority and honor and often feel like these are the better "teaching" jobs. There are often questions about where resources are allocated 
concerning IB and non-IB. Politically speaking, there seems to be unrest around this topic.

The leadership team as whole works within the skills approach theory, all of them bringing different skill sets to the table. Some are more task oriented, some more people oriented, and some more idea oriented. All of these areas are needed at Central High School, especially as they are navigating the IB Program and how it fits in to the school as a whole. Recently, focus has been placed on growing the new IBCP Program, as well as revitalizing the MYP Program. Different leaders and different forms of leadership have had to emerge for this growth to happen, and it is evident that different people are stepping up to meet this challenge. Having more voices and different leadership involved in the implementation of the overall IB Program and taking notice of how it influences Central students and staff as a whole, is something much needed.

Because of the above items, implications for research can be very positive. For example, taking on a broader view of the impact of the IB Program on the school is necessary, and it is possible it will take fresh eyes to accomplish this. This research has the potential to expand and grow the IB program if leadership is willing to look at the results and to both hear and act on what students and staff are saying. This research also has the potential to shine a light on, as well as help address any negative impacts on school culture from the implementation of IB. 
Section Three-Scholarly Review 
In 1983 the National Commission on Excellence in Education released its report, A Nation at Risk. It warned of mediocrity in American school systems by painting a bleak picture of current education by citing risk indicators and sharing a quote from then president, Ronald Regan: “This public awareness--and I hope public action - is long overdue...this country was built on American respect for education...Our challenge now is to create a resurgence of that thirst for education that typifies our Nation's history" (National Commission on Excellence in Education, 1983). Metha (2015) wrote about the effects of this report in his article, Escaping the shadow: A nation at risk and its farreaching influence. He stated when the report was released it "invoked a crisis so farreaching in its impact that it still governs the way we think about public education 30 years later" (Metha, 2015, p. 20). The consensus seems to be that public education is failing and in need of reviving (Alliance for Excellent Education, 2009; Matthews \& Hill, 2005; Schlechty, 1997; Wilkinson \& Hayden, 2010).

The answer then, when a public school is failing or in danger, is often to introduce an outside program. Within recent years, the International Baccalaureate Program, or IB, has been one of the programs introduced into public schools as a transformative force, one that can change school culture, as well as student attitudes and achievement (Connor, 2008; Drake, 2004; Mayer, 2008). However, research to support the claim that implementation of IB has a positive impact on schools, specifically school culture, is either missing, or largely slanted toward a positive IB experience. Unbiased data and research are somewhat hard to find since much of the literature related to IB is often funded by IB and can have a positive, biased slant toward the IB Program. 
Within the parameters of this study, I examined the IB Program and its implementation and influence on school culture in one particular case study, a diverse high school in Springfield, Missouri. The guiding research questions were as follows: (a) Based on staff and student perceptions, what is the current culture at Central High School? and (b) What is the role of International Baccalaureate in that culture?

Because the research questions were specific to culture and how the IB Program has affected culture, there will be four specific areas of scholarly review informed this research; they were as follows: (a) organizational culture, specifically school culture; (b) critical theory as it applies to marginalized groups within a school setting; (c) leadermember exchange theory as it applies to creating "in-groups" and "out-groups" within a school setting; and (d) a brief overview of the International Baccalaureate Program and specific studies surrounding IB, and its implementation into other school settings.

\section{Organizational Culture}

Organizations can be hard to understand for many reasons. According to Bolman and Deal (2013) in their book, Reframing Organizations: Artistry, Choice, and Leadership, they can be complex, surprising, deceptive, and ambiguous. Bolman and Deal (2013) broke organizations down into four distinct frames by which to define an organization and explain its inner workings. According to Bolman and Deal (2013), organizations can be examined through a human resource lens, a structural lens, a political lens, or a symbolic lens. Early researchers have stated that organizations are two sided, one being an "economy" and the other being an "adaptive social structure" (Selznick, 2005, p. 125). This study examined organizations like a school setting through the symbolic, or cultural lens as an adaptive social structure. Culture has the ability to 
define, change, and maintain an organization and it exists in all places, whether in nations, religious groups, homes, or in schools (Bolman \& Deal, 2013; Deal \& Peterson, 2016; Schein, 2005, 2010). What is culture? And specifically, what is school culture? This section answered those two questions, as well as examined the common pillars of culture as cited by experts in the field. For the purpose of this study, there were four pillars utilized when collecting data; they were as follows: (a) shared values and beliefs, (b) norms and rules, (c) symbols and artifacts, and (d) language (Bolman \& Deal, 2013; Deal \& Kennedy, 1982; Deal \& Peterson, 2009, 2016; Gruenert \& Whitaker, 2015; Manning, 2013; Schein, 2005, 2010).

\section{Culture Defined}

The broadest definition of culture has its roots in anthropology where researchers have used it to refer to historical societies, tribes, and national or ethnic groups, as well as their customs, rituals, and language (Deal \& Peterson, 2016; Manning, 2013; Schein, $2005,2010)$ and yet, to define what culture is can be somewhat subjective and abstract. Manning (2013) called it a "ubiquitous" and "elusive concept" (p. 90). Schein (2010) agreed by further stating that culture is a concept that "points us to phenomena that are below the surface, that are powerful in their impact but invisible and to a considerable degree unconscious" (p. 14). Bolman and Deal (2013) furthered this idea surrounding culture by stating that "it is easy to recognize and impossible to define. It is a mystique" (p. 272). Subjective, yet powerful is a good way to explain culture as Schein (2010) additionally stated that "Cultural forces are powerful because they operate outside of our awareness" (Schein, 2010, p. 7). 
Culture is always present. It weaves its way in and out of everything people do, often managing and influencing their thoughts, words, and actions. Culture then, is not just created and then left alone to be studied. It is both created and creates simultaneously. It is an ever living, moving, and changing environment dependent on the actions of people who live and work within the culture. Parker (2000) asserted in his book, Organizational Culture and Identity, that "Organizational culture is a process which is locally produced by people, but...it can also be usefully talked about as a thing with particular effects on people...it is both a verb and a noun" (p. 83). Similarly, Bolman and Deal (2013) concluded the same idea when referring to culture as both a product and a process. "As a product, it embodies wisdom accumulated from experience. As a process, it is renewed and re-created as newcomers learn" (p. 263). People are both consistently shaping culture and being shaped by culture.

Culture in its broadest sense can be thought of as the "foundation of the social order that we live in and of the rules we abide by" (Schein, 2010, p. 3). However, it can be divided into several specific terms. Macro cultures refer to nations and/or ethnic and religious groups. They exist globally. Organizational cultures can be either private or public, non-profit or government organizations. When broken down even further than that, subcultures and microcultures can be found within organizational and macrocultures (Schein, 2010). For the purpose of this research, the focus was on organizational culture, specifically, school culture.

Generally speaking, most people have a sense of what culture is, but struggle to put it into words or define it completely. Many references were made in work places to "it", how "it" exists, and how "it" affects those in the environment, but they cannot say 
what "it" is. Researchers also continue to debate what "it" is as shown by the multiple research approaches to the concept of culture. According to current research, culture can be defined as the "glue" and "stuff" that holds organizations together (Manning, 2013, p. 92). Deal and Kennedy (1982) simply stated "culture is the way we do things around here" (p. 4). When looking for a more formal definition of culture, Schein (2010) stated culture can be defined as "a pattern of shared basic assumptions learned by a group as it solves its problems of external adaptation and internal integration...to be taught to new members as the correct way to perceive, think, and feel" (p. 18).

According to Schein (2010), culture must be both patterned and stable in order for it to exist. To say something is "cultural" implies it is shared but also stable. In order for a culture to be stable, Schein asserted it has three components: (a) depth, (b) breadth, and (c) patterning or integration. Depth of a culture refers to how deeply embedded it is into a group. "Culture is often the deepest, often unconscious part of a group and is therefore less tangible and visible (Schein, 2010, p. 16). Breadth of a culture refers to its ability to influence all aspects of an organization. It "covers all of a group's functioning" (Schein, 2010, p. 17). Lastly, patterning or integration refers to cultures ability to tie everything together into a coherent whole, bringing people together to mimic patters and integrate into the system. Schein (2010) argued "the most fundamental characteristic of culture is that it is a product of social learning" (p. 17).

\section{School Culture Defined}

Trying to define and make sense of school culture is no easier than making sense of organizational culture. Culture within a school system carries the same unseen nuances that any other organizational culture carries. McMaster (2015) stated, "The fact 
that culture is largely unseen is why a clear definition of culture has been so elusive" ( $p$. 21). He goes on to give a similar definition of culture; "Culture is something that is multi-layered and complex, with deep underlying assumptions and beliefs influencing behavior and expression in ways that are often unspoken and taken for granted" (p. 21). School systems are part of a wider circle of society, and therefore will take on similar aspects of the wider societal values (McMaster, 2015). That being said, every school system and building will have a culture that is all its own; therefore, school culture will take on much the same definition of organizational culture. One of the earliest researchers on school culture, Willard Waller (1932) in his book, The Sociology of Teaching, stated this about school culture: "Schools have a culture that is definitely their own. There are, in the school, complex rituals of personal relationships, a set of folkways, mores, and irrational sanctions, a moral code based upon them" (p. 96). Current researchers have found similar insights as Waller. Deal and Peterson (2009) stated school culture is the "glue, the hope, and the faith that hold people together" (p. 5) and the "unofficial pattern that seems to permeate everything" (p. 5).

Much like organizational culture, school culture is vastly important because it dictates, at times unspoken, the operational rules in an educational setting (Barth, 2002). Barth (2002) stated in his article, The culture builder, that "A school's culture has far more influence on life and learning in the schoolhouse than the president of the country, the state department of education, the superintendent, the school board, or even the principal, teachers, and parents can ever have" (Barth, 2002, p. 6). Understanding school culture is vital to a school's success, so it is imperative educational leaders become familiar with what culture is and how it can affect a school system (Deal \& Peterson, 
2009, 2016; Gruenert \& Whitaker, 2015). Deal and Peterson (2016) summarized early researchers in which an established "school ethos" was a prime contributor to academic achievement (p. 10). School culture influences everything from conversations in the teachers' lunchroom to the use of data and the nature of problem solving. Deal and Peterson (2016) listed several examples of how school culture can permeate everything within the building. It can foster school effectiveness and productivity, improve collegiality and communication, promote innovation and improvement, build commitment and kindle motivation, amplify energy and trust of staff members, and focus attention on what is important and valued (Deal \& Peterson, 2016). They also stated that a positive school culture has the ability to improve teaching and learning, create a group sense of efficacy, cultivate a sense of excellence, increase student performance, and is a crucial factor for success within the school buildings (Deal \& Peterson, 2016).

However, Deal and Peterson (2016) also suggested that schools are in danger of losing their cultures, that they are drifting into something different, and liken it to losing their souls. "In most schools, this shift has been caused by the unintended consequences of continuous rigid legislative mandates and 'reform' as much as by local neglect" (Deal $\&$ Peterson, 2016, p. 5). This can cause concern for educational leaders who understand the importance of school culture and the impact it has on performance, school improvement, and ways of thinking for both students and staff alike. "Everything, and we do mean everything, in the organization is affected by culture and its particular form and features" (Deal \& Peterson, 2016, p. 9).

In their book, School culture rewired: How to define, assess, and transform it, Gruenert and Whitaker (2015) mirrored this thought and extended it by stating within the 
school system "culture is both a survival mechanism and a framework for solving problems" (p. 4). Problems are seen every day in the educational world, and if culture is both how people survive and how they solve problems, extra care should be taken to learn about it, including questions about school culture in general and how a particular school culture evolved. Martin (2002) answered the question about why educational leaders should even bother to study culture by stating that it generates commitment and increases productivity, which would be highly valuable in the school setting. Habegger (2008), in her article, The principal's role in successful schools: Creating a positive school culture, mimicked these thoughts when sharing how culture can positively influence the school setting. According to Habegger (2008), the impact of school culture can create a sense of belonging and provide clear direction for students, staff, parents, and community. She stated "a positive school culture is the underlying reason why the other components of successful schools were able to flourish" (Habegger, 2008, p. 44).

Defining school culture can prove to be a monumental task. For a clearer picture, it is helpful to state what school culture is not. School culture is not the same thing as school climate. It is a small nuance, but one worth noting as the research for this paper will examine what school culture is. In order for that to be effective, there must be an explanation of what school culture is not. Deal and Peterson (2016) gave such an explanation.

For decades, terms such as climate and ethos have been used to try and capture this powerful, pervasive, and notoriously elusive force. We believe the term culture provides a more accurate and intuitively appealing way to help school leaders better 
understand their school's unwritten rule and traditions, customs, and expectations. (p. 7)

Gruenert and Whitaker (2015) asserted one of the best ways to understand school culture is to contrast it with school climate. "One of the things that makes culture so difficult to change is that it's so hard for us to pinpoint - it is always easier to describe what you do (climate) rather than why you do it (culture)" (Gruenert \& Whitaker, 2015, p. 16). Culture can be described as a group's personality, whereas climate is the group's attitude. Culture is a part of us, whereas climate surrounds us. If culture is "the way we do things around here," then climate is "the way we feel around here." This means culture cannot be felt when one walks in the room, whereas climate can be felt immediately. More importantly, culture takes years to evolve, whereas climate is easily changed (Gruenert \& Whitaker, 2015).

As a researcher examining school culture, it is imperative to have a clear picture of what school culture is and what it is not. Within a school building, the influence of culture is everywhere. "The unofficial patterns seem to permeate everything: the way people act, how they dress, what they talk about or consider taboo, whether they seek out colleagues or isolate themselves, whether they work together, and how teachers feel about their work and their students" (Deal \& Peterson, 2016, p. 7). Because the concept of culture can be so vast, within this research, four specific pillars of culture will be utilized to provide the primary data and focus.

\section{Four Pillars of Culture Defined}

Because culture is such a hard concept to define, it is essential that a deeper, more complex model of culture is built, using a wider range of observable items (Schein, 
2010). There is much to be gleaned about what creates a culture, who creates a culture, and how that culture grows and permeates the people and things around it (Bolman \& Deal, 2013; Deal \& Kennedy, 1982; Deal \& Peterson, 2009, 2016; Gruenert \& Whitaker, 2015; Manning, 2013; Schein, 2005, 2010). Schein (2010) divided culture into three very specific levels. One level is artifacts, including visible and feel-able structures along with observable behaviors. The second level is espoused beliefs and values. This would include goals, aspirations, ideologies, and rationalizations. The third level is basic underlying assumptions, which would include the unconscious, taken for granted beliefs and values. Schein listed several observable traits that exist within culture and help to define it. These are group norms, values, formal philosophy, rules, climate, linguistic paradigms, shared meanings, metaphors and symbols, and formal rituals (Schein, 2010).

Similarly, Bolman and Deal (2013) separated organizational culture into different symbols. "An organization's culture is revealed and communicated through its symbols" (p. 248). According to Bolman and Deal (2013), symbols can take several different forms within an organization. The list includes: (a) myths, vision, and values, (b) heroes and heroines, (c) stories and fairytales, (d) rituals, (e) ceremonies, and (f) metaphors, humor, and play. Symbols within an organization can tell the "story behind the story" (Bolman \& Deal, 2013, p. 249). They also characterize what an organization stands for, convey identity and sense of purpose, as well as give a vision for the future. For example, heroes and heroines play the part of "living logos, human icons, whose words and deeds exemplified and reinforced important core values" (Bolman \& Deal, 2013, p. 252). Similarly, stories and fairytales can communicate who you are, transmit values, share knowledge, and even lead people into the future. Rituals are routines that convey 
meaning. They can be both powerful and palpable. Ceremonies are similar to rituals in the fact that they create order, clarity, and predictability; however, they tend to be more elaborate. "Ceremonies often weave several rituals in concert and are convened a times of transition or on special occasions" (Bolman \& Deal, 2013, p. 260). Lastly, metaphors can make the strange familiar and the familiar strange, while humor can either distance or bring people together (Bolman \& Deal, 2013).

Other researchers define culture in similar ways to Schein (2010) and Bolman and Deal (2013). Martin (2002) broke culture into formal or informal practices as well as used similar ideas to convey the concept as culture. These include behavioral norms, stories, rituals, humor, language and jargon, dress, and values. Manning's (2013) breakdown of culture has several similar observable traits to the ones that have already been mentioned. These include metaphors, structure, values and assumptions, subcultures, history and tradition, priests and storytellers, as well language, symbols, and architecture (Manning, 2013). According to Manning (2013), using these types of traits to define culture can provide understanding to the intangible aspects of the organization as well as create meaning beyond the day to day bureaucracy.

Most researchers agree that culture must be reduced to observable traits, and there is much crossover in what those traits are. When examining and evaluating an already established culture, it is necessary to have a list of "look-fors" or "pillars" when collecting data (Bolman \& Deal, 2013; Deal \& Kennedy, 1982; Deal \& Peterson, 2009, 2016; Gruenert \& Whitaker, 2015; Manning, 2013; Martin, 2002; Schein, 2005, 2010). For the purpose of this study, four pillars of culture will be utilized for data collection. 
They are as follows: (a) shared values and beliefs, (b) norms and rules, (c) symbols and artifacts, and (d) language.

Shared values and beliefs. Values and beliefs define what at organization stands for while also sharing qualities found important by a group of people. They can be both publicly announced or privately followed, but they help to convey an identity and a sense that people are working for something greater than themselves. This can also include aspects such as a mission statement, working philosophy, or vision for the organization (Bolman \& Deal, 2013; Deal \& Kennedy, 1982; Deal \& Peterson, 2009, 2016; Gruenert \& Whitaker, 2015; Manning, 2013; Martin, 2002; Schein, 2005, 2010). According to Bolman and Deal (2013), "values are intangible and define a unique distinguishing character. Values convey a sense of identity... and help people feel special about what they do" (p. 249). Values and beliefs are the underlying current pushing people forward, guiding their words and actions. Deal and Peterson (2016) took the definition a bit further when they stated that values "are the conscious expression of what an organization stands for. Values define a standard of goodness, quality, or excellence that undergirds behavior and decision making and influences what people care about" (p. 75).

Norms and rules. Norms and rules can be both spoken and written, or implicit and unwritten. Group norms and rules can also be either formal, such as in a handbook, or informal, such as "the way we do things around here" (Bolman \& Deal, 2013; Deal \& Kennedy, 1982; Deal \& Peterson, 2009, 2016; Gruenert \& Whitaker, 2015; Manning, 2013; Martin, 2002; Schein, 2005, 2010). Norms consolidate values and beliefs, as well as govern things like behavior, dress and language. These norms and rules have the ability to become unconscious, deeply held "behavioral blueprints" that can reinforce 
how people act and interact, shaping everything from feelings, behaviors, thinking, and relationships between people (Deal \& Peterson, 2016, p. 76). Often the norms are considered the "unwritten rules for getting along in the organization, 'the ropes' that a newcomer must learn to become an accepted member" (Schein, 2010, p. 15). Within a school setting this can look like anything from helping new staff members acclimate, to speaking with pride about one's school and department, to placing the needs of students above personal agenda. There can also be negative norms. These might look like not making waves and remaining locked in one's own classroom, bullying new staff members, or keeping new ideas and strategies to oneself (Deal \& Peterson, 2016). Symbols and artifacts. Symbols and artifacts can be found everywhere. They are the tangible pieces of what makes up an organization. According to Bolman and Deal (2013), "symbols carry powerful intellectual and emotional messages; they speak to both the mind and the heart” (p. 243). Symbols and artifacts are often used to build a distinctive and unique identity with the ability to create within an organization meaning and significance that influences thoughts, motivation, and behavior (Bolman \& Deal, 2013; Deal \& Kennedy, 1982; Deal \& Peterson, 2009, 2016; Gruenert \& Whitaker, 2015; Manning, 2013; Martin, 2002; Schein, 2005, 2010). Deal and Peterson (2016) stated that symbols and artifacts represent the intangible values and beliefs that can prove to be difficult to express in other ways. "They are the outward manifestation of those things we cannot comprehend on a rational level...they are cultural rallying points" (Deal \& Peterson, 2016, p. 37). Very simply put, “an organization's culture is revealed and communicated through its symbols" (Bolman \& Deal, 2013, p. 248). Within a school setting these symbols and artifacts may look like anything from the mascot, to banners 
and displays of student work, to historical collections and photos (Deal \& Peterson, 2016).

Language. Language and linguistic paradigms are shared cognitive frames that guide members of the group and are taught to new members early in the socialization process (Schein, 2010). The language within a culture helps to clarify the boundaries between those who are a part of the culture and those who are not. Particular jargon or turns of phrase can help to define a culture in any particular setting, helping to create a clear picture of what the culture is, as well as who belongs to it and who does not. There are often distinct vocabularies and phrases used within a school setting that let people know who is informed and who is not (Gruenert \& Whitaker, 2015). According to Gruenert and Whitaker (2015), "to not understand the local language is to demonstrate a lower level of usefulness in the eyes of the culture" (p. 32). Language within a school setting can be both formal and informal and can come in the forms of titles, nicknames, professional verbiage, or slang terms.

\section{Summary of Organizational Culture}

The concept of culture has its roots in anthropology as historians and researchers historically tried to describe tribes, religions, and people groups. Even so, culture is an abstract and subjective idea. Bolman and Deal (2013) even stated culture "is easy to recognize and impossible to define. It is a mystique" (p. 272). Subjective, yet powerful is a good way to explain culture as Schein (2010) additionally stated that "Cultural forces are powerful because they operate outside of our awareness" (Schein, 2010, p. 7).

In the broadest sense of the word, culture can be thought of as the "foundation of the social order that we live in and of the rules we abide by" (Schein, 2010, p. 3). Every 
person and every place has a culture attached to it. Culture can be seen in all places, such as athletic arenas, organizations, businesses, and even schools. Much like organization culture, school culture is vastly important because it dictates, at times unspoken, the operational rules in an educational setting (Barth, 2002).

However, even though trying to define culture can be difficult, it can also be broken down into more manageable pieces in order to be researched. Breaking culture down into smaller categories can help serve as guideposts for others when studying culture. For the purposes of this study, organizational and school culture will be examined at using the following four pillars: (a) shared values and beliefs, (b) norms and rules, (c) symbols and artifacts, and (d) language.

Shared values and beliefs define what at organization stands for. This would include things like the mission statement, and the school's vision or philosophy. Norms and rules can be both written or unwritten, formal or informal. These norms and rules are an expression of "the way we do things around here". Symbols and artifacts are tangible pieces of school culture and look like anything from school colors and mascots to student work hanging on the walls. Lastly, language helps to clarify the culture, including who is a part of the culture and who is not. This includes particular jargon used by a certain group, both formal and non-formal.

\section{Critical Theory}

To be critical means to judge or discern something. The foundation of critical theory can be traced back to Max Horkheimer, a German philosopher and sociologist. He stated that critical theory "seeks to liberate human beings from the circumstances that enslave them" (Horkheimer, 1972, p. 244). Other early work was derived from Karl 
Marx and focused on social progress as well as a class based society (Kezar, Carducci, \& Contreras-McGavin, 2006). Creswell (2014) mimicked this definition by stating that "critical theory perspectives are concerned with empowering human beings to transcend the constraints placed on them by race, class, and gender" (p. 65). In its simplest definition, critical theory examines social conditions and how they create unequal power relations (Merriam \& Bierema, 2014; Merriam \& Tisdell, 2016). In its more complex definition, there are several areas of critical theory, including race theory, gender studies, queer theory, and feminist theory, etc. For the purpose of this study, the researcher defined critical theory in its broadest terms and specifically, critical theory as it relates to school culture and marginalized student populations.

\section{Critical Theory Defined}

According to critical theory, the goal of research is to "critique and challenge, to transform and empower" (Merriam \& Tisdell, 2016, p. 10) by reflecting on societal assumptions and beliefs as well as studying concepts from a different viewpoint. According to researchers, critical theory seeks to do three important things: (a) examine and critique social conditions, (b) challenge "truths" and ideologies set by dominate social groups while examining power relations created within society, and (c) emancipate marginalized people groups and eliminate oppression of these people groups (Kezar, Carducci, \& Contreras-McGavin, 2006; Merriam \& Bierema, 2014; Merriam \& Tisdell, 2016).

Merriam and Bierema (2014) stated very simply that "critical theory critiques social conditions" (p. 214). Examining and critiquing social conditions is a pillar of critical theory. To critically examine a social condition is to reflect on assumptions and 
beliefs associated with it, as well as try to connect individual experiences to the broader social condition. Being a critical thinker shifts the focus from individuals to the bigger social context that help shape how people interact with others and their environment (Merriam \& Bierema, 2014). Critical theory asks specific questions about social environments, such as "Who benefits from these arrangements?" and, "Who says X is true?” (Merriam \& Bierema, 2014, p. 215). The critical perspective assumes people unconsciously reinforce the status quo by accepting the way things are. Critical research hopes to bring light to these types of dynamics.

Critical theory also challenges "hegemony, or the process of the dominant group creating 'truths' that become accepted as the natural and right way to think about something" (Merriam \& Bierema, 2014, p. 214). These ideologies can be found in everyday situations and practices and help shape behavior to keep an unequal system intact. Dominant ideologies or 'truths' are created by dominant groups who have power. Unequal power relations are created in every cultural setting, whether it is nationally, organizationally, or in a school. This difference in power will always produce the haves and the have-nots (Merriam \& Bierema, 2014). Indeed, Merriam and Tisdell (2016) stated that "power dynamics are at the heart of critical research" (p. 61).

Power and privilege are two sides of the same coin. People who find themselves in a marginalized group tend to be those on the non-dominant side of the power dynamic. Johnson (2006) stated that "The trouble that surrounds difference is really about privilege and power - the existence of privilege and the lopsided distribution of power that keeps it going” (p. 12). According to French and Raven (1959) in their article, The bases of social power, there are five bases of power. These are referent, expert, legitimate, 
coercive, and reward. They further stated the processes of power are "pervasive, complex, and often disguised in our society" (p. 150). Bolman and Deal (2013) named the same bases of power, but also included power by information, reputation, and alliances. Research that uses critical theory as a lens is "interested in power and how the powerful shape what we accept as knowledge and truth in society" (Merriam \& Bierema, 2014, p. 215).

Lastly, critical theory will seek to emancipate marginalized people groups and eliminate oppression of these people groups (Merriam \& Bierema, 2014; Merriam \& Tisdell, 2016). Within critical theory and critical research, the goal is to not only think and reflect, but to act. Critical action involves clarifying or changing thought, altering behavior, making timely interventions, and justifying actions (Merriam \& Bierema, 2014; Merriam \& Tisdell, 2016). Critical theory is not just about thinking, but about acting as well. "It is using our insight to inform our actions" (Merriam \& Bierema, 2014, p. 226). Within critical theory research, the goal is to help others understand and challenge power relations. In most critical studies, "the hope is often that people will take action...it aims to critique existing conditions and through that critique bring about change" (Merriam \& Tisdell, 2016, p. 59).

\section{Critical Theory Within the School Setting}

Merriam and Bierema (2014) stated critical minds "ask questions about social conditions" (p. 215). This includes asking questions regarding school culture. In fact, schools are a microcosm of larger society, meaning it too has dominant and nondominant groups with power dynamics in play, as well as marginalized people groups, coming in the form of students and staff alike. Looking at the implementation of IB and 
its influence on school culture through the critical theory lens would investigate how these specific areas and people groups have been affected. Based on the ideas of critical theory, critical educational leaders should constantly be thinking about how school structure and culture is set up within their buildings. Merriam and Tisdell (2016) asserted that "critical educational research examines the context where learning takes place, including the larger systems of society, the culture, and institutions that shape educational practice" (p. 61).

Within the school setting this would include examining the culture of the school, how it came to be, and where the power and resources within the school setting lie. Specific questions should be asked of educational leaders to gain more insight on power dynamics, as well as who the dominant and non-dominant groups within the school are. Merriam and Tisdell (2016) further stated that questions should be asked "regarding whose interests are being served by the way the educational system is organized, who really has access to particular programs, who has the power to make changes, and what outcomes are produced by the way in which education is structured" (p. 61). Asking these sorts of critical questions will give insight on power relations and how some interest groups are advanced while others remain oppressed (Merriam \& Tisdell, 2016).

There is much research examining the idea of marginalized student groups and how educational resources are allotted. Theoharis (2008) in his article, Woven in deeply: Identity and leadership or urban social justice principals, stated "addressing and eliminating marginalization in schools is a critical component" (p. 5). He also cited educational leaders and administrators as enacting social justice for marginalized students. One principal shared, "I do this because there are not enough other principals 
who deeply care about the kids from the margins and who can make equity and justice happen" (p. 3). Another study by Hernandez and McKenzie (2010) declared very simply that the achievement gap continues to widen between affluent students and lower socioeconomic students and between white students and students of color. "In addition to these achievement gaps, marginalizing practices are often imbedded in the structures of schooling; for example, culturally and linguistically diverse students are both segregated from their school peers throughout the school day and overrepresented in special education and other remedial education programs" (Hernandez \& McKenzie, 2010, pp. 48-49). Additional research from Madsen and Mabokela (2014) in their article, Leadership challenges in addressing changing demographics in schools, stated "leaders define the organizations culture, determine which groups get power, and define the very nature of power" (p. 87).

Research makes a case that looking at school culture through a critical lens can be helpful in both identifying and challenging certain values and beliefs within the school system that may keep certain student populations marginalized. In his article, African American educational leadership: Critical, purposive, and spiritual, Dantley (2009) shared the same sentiment. "The whole point of critical theoretical thought is not only to unmask those systemic ways in which institutions such as schools marginalize and disenfranchise those deemed to be outside of the accepted traditions and classifications, but also to propose an oppositional arrangement of these institutions" (p. 45).

\section{Summary of Critical Theory}

Critical theory has its roots in German philosophy. In its simplest definition, critical theory examines social conditions and how they create unequal power relations 
(Merriam \& Bierema, 2014; Merriam \& Tisdell, 2016). When studied in a deeper way however, the goal of research within critical theory is to "critique and challenge, to transform and empower" (Merriam \& Tisdell, 2016, p. 10) by reflecting on societal assumptions and beliefs as well as studying concepts from a different viewpoint. Critical theory accomplishes this goal by examining and critiquing social conditions, challenging truths, and emancipating marginalized people groups (Merriam \& Bierema, 2014; Merriam \& Tisdell, 2016).

Critiquing social conditions is a pillar of critical theory. Daily self-assessment and reflection as well as asking questions about why an organization is set up a certain way are good places to start when looking at a culture through the lens of critical theory. Critical theory will also challenge the rules and norms of the dominant group as well as bring about change to marginalized groups of people. This includes the use of critical theory when researching a school setting.

Schools are a microcosm of larger society; it too has dominant and non-dominant groups with power dynamics in play, as well as marginalized people groups, coming in the form of students and staff alike. Research continues to show achievement gaps between certain student groups, as well as groups of students who continue to be separated or marginalized. Looking at the school culture through the lens of critical theory can be helpful in bringing about a change within that specific school.

\section{Leader Member Exchange Theory}

Leader-member exchange theory is an approach that sees leadership as a process, examining the interactions between a leader and followers. The focal point of this theory is the relationship between leader and follower. Most leadership theories assume that 
leaders treat followers as a collective group, acting the same towards all followers. The LMX theory, however, challenges this assumption and studies the differences that may exist between a leader and each follower (Lunenburg, 2010; Northouse, 2016). Research shows that "leaders often act very differently toward different subordinates, and develop contrasting kinds of relationships with them" (Lunenburg, 2010, p. 1). This section will define the leader leader-member exchange (LMX) theory as well as how this theory relates to the school system.

\section{Leader Member Exchange Theory Defined}

Within the LMX theory, leaders create dyadic relationships with followers. Each leader-follower relationship has its own dyad. When examining these dyadic relationships between the leader and followers, researchers found two different types of interactions or relationships. The first kind of dyadic relationship was considered the "ingroup" and the second kind of dyadic relationship was considered the "out-group" (Lunenburg, 2010; Northouse, 2016). According to Northouse (2016), "followers become a part of the in-group or the out-group based on how well they work with the leader and how well the leader works with them. Personality and other personal characteristics are related to this process" (p. 138). In his article, Leader-Member Exchange theory: Another perspective on the leadership process, Lunenburg (2010) explained that the roles of the "in-group" and "out-group" as well as their relationship with the leader are very different from each other. The "in-group" followers in the leader's inner communication circle are given more latitude in their roles, along with greater responsibilities and rewards. The opposite is true of the "out-group." These 
followers are outside the inner circle, have less responsibility and rewards, and are controlled by rules and policy (Lunenburg, 2010).

Research shows the "in-groups" and "out-groups" are initiated by the leader's interaction with the followers, and they may be picked unconsciously based on the leader's preferences or personality. According to Lunenburg (2010), research shows leaders do pick their followers and these picks are not random. Leaders are more likely to form "in-group" relationships with followers who have a high degree of self-efficacy, but also who were perceived by the leader to be more similar in personality. "Furthermore, perceived similarities between the leader and follower...led to greater liking of subordinates and higher quality leader-member exchanges" (p. 2). The perception of similarity was more important than anything else. When leaders are not aware of these unconscious thoughts, decisions, and relationships, it can influence who is chosen to be a part of the "in-group" and who is chosen to be a part of the "out-group" (Lunenburg, 2010; Northouse, 2016). The suggestion is some members or followers receive special attention and some do not. This theory "supports the development of privileged groups in the work place. In so doing, it appears unfair and discriminatory" (Northouse, 2016, p. 147).

Research also states the better relationship between the leader and follower, "the higher the productivity, job satisfaction, motivation, and citizenship behavior or the follower (Lunenburg, 2010, p. 3). Earlier research by Allport (1974) in his book, The nature of prejudice, devotes a chapter to the idea of in-groups and out-groups. He stated people learn to form in-groups at a very early age and that they are always based on likeness and similarity. He then posed the question, "Can there be an in-group without an 
out-group?" (p. 41). The answer, it seems, is no. Allport continued by stating "in-groups are psychologically primary. We live in them, by them, and sometimes for them. Hostility towards out-groups strengthens our sense of belonging, but it is not required" (p. 42).

This same idea is presented by Banaji, Bazerman, and Chugh (2015) in their article, How unethical are you? They suggested that as a leader one may have unconscious biases, therefore creating several problems within an organization or workplace, one of them being in-group favoritism. Banaji, Bazerman, and Chugh (2015) described this as "granting favors to people with your same background - your nationality or alma mater - effectively discriminates those who are different from you" (p. 118). In their book, Blindspot: Hidden biases of good people, Banaji and Greenwald (2013) presented the same thought process of "in-groups" and "out-groups", calling it an "us" and "them" mentality. This type of mentality can creep in unnoticed because people are prepared to "favor the familiar" (p. 126). Often it is not that one group is being treated badly and one group well, but instead one group is being treated better. Research shows people prefer members based on familiarity or similarities and the "psychology of 'us' and 'them' rushes in to fill the void. Lines are drawn, whether or not the basis for the groups makes any sense, and discrimination follows" (Banaji \& Greenwald, 2013, p. 136).

The Leader Member Exchange theory can be helpful or harmful, depending on what leaders do with it. If leaders remain unaware that they unconsciously create ingroups and out-groups with followers around them, bias and unequal treatment will remain in the workplace or organization. If leaders are aware of it, they can actively 
work to combat those biases that create an in-group and an out-group and instead create special relationships with each follower, "thus making the entire work unit an in-group" (Northouse, 2016, p. 145).

\section{Leader Member Exchange Theory Within the School Setting}

As seen in the previous section, marginalized groups within the school system are no novel idea. The LMX theory stated that based on leader and follower exchanges, there is always an "in-group" and an "out-group" created within an organization, or in this case, a school setting (Northouse, 2016). Gruenert and Whitaker (2015) seconded this statement by defining culture as "patterns of behavior that distinguish us from them" (p. 6). This should communicate to leaders in the educational system that there is always a culture within the school and often, this culture can create an "us and them" mentally, or as Northouse (2016) explained it, an "in-group" and an "out-group."

Studies pertaining to LMX within the school system show results in keeping with the main points of the theory. Any follower, whether that be student or adult, generally performs higher and cites being happier in their place of work when they are involved in

a good relationship with their leader (Clemens, Milson, \& Cashwell, 2009; Mauro, 2007; Mosley, Broyles, \& Kaufman, 2014; Power, 2013).

Mosely, Broyles, and Kaufmann (2014) found relationships between teachers and students can vary, and the students who have a higher quality relationship with teachers will do more than required. This study also found teachers can influence their students in terms of instructional guidance, student achievement, and even motivation based on the quality of their relationship. Another study by Mauro (2007) found similar results around LMX theory within the school buildings. "Out-group" members became alienated 
resulting in lower performance and increased turnover. As a result, homogeneity increased, "leading to even less diversity and an entrenchment of perspectives" (Mauro, 2007, p. 27). Clemens, Milson, and Cashwell (2009) found similar results within their study around principals as leaders and school counselors as followers. The leadermember exchange theory can be seen working in every aspect of the school system, in every leader and follower relationship, no matter who is in what role.

Research shows leaders, no matter what kind, produce and maintain "in-groups" and "out-groups" based on their relationships with their followers. Research also shows that followers, no matter if they are students or teachers, adolescents or adults, perform better and are more motivated when they are a part of the "in-group" instead of the "outgroup." Da and Liang (2004) stated in their research the "in-group" is regarded as highquality people while the "out-group" is considered low quality people. If this is true of students within a school building, it is possible that as educational leaders we are not only creating, but maintaining and perpetuating marginalized student groups within a school culture by deciding who belongs to the "in-group" and who belongs to the "out-group."

Linking LMX to school culture is a rather small step, as both are defined by the same concept. Allport (1974) suggested a child as early as age five is able to understand that he or she is a member of various groups, who is rewarded by simply being a member, and therefore teaching loyalty. He affirmed "in-groups" are formed by simply being able to use the term "we." This concept is pervasive across all lines, people groups, organizations, and school systems. Within a school building there is a school culture, and within that school culture, there are "in-groups" and "out-groups," an "us" and "them" mentality. Allport (1974) said, "all groups (whether in-groups or reference 
groups) develop a way of living with characteristic codes and beliefs, standards and enemies to suit their own adaptive needs" (p. 39). This statement is the very definition of culture, and presents the idea again that culture is not static but instead fluid, ever changing, and growing.

Deal and Peterson (2016) maintained there can be a negative side to school culture; it has the ability to create noxious, mean-spirited, and hostile environments. Within a school system, "in-groups" and "out-groups" have the ability to create just such an environment. Both groups are affected by culture and yet at the same time, can affect the culture in which they find themselves. It is imperative as school leaders that we understand this concept. Power (2013) stated in his article "leaders who understand the significance of LMX are empowered with the understanding that they need to avoid the creation of out-groups wherever possible and maximize the size of the in-group upon which they can rely" (p. 279).

\section{Summary of Leader Member Exchange}

Leader-member exchange theory is an approach that sees leadership as a process, examining the interactions between a leader and followers (Lunenburg, 2010; Northouse, 2016). This theory is focused specifically on the relationship between the leader and the follower. The LMX theory states that leaders create in-groups and out-groups within an organization, based on their relationship with their followers. According to LMX theory, leadership will give special attention and treatment to in-groups as well as more of their time and support (Northouse, 2016).

This is also true within the school setting. The LMX theory stated based on leader and follower exchanges, there is always an "in-group" and an "out-group" created within 
an organization, or in this case, a school setting (Northouse, 2016). Often times within a school setting in-groups and out-groups are created by students and their peers.

However, based on research from LMX theory, these in-groups and out-groups within the school setting are also happening based on teacher and student relationships. The ingroups and out-groups that happen within a school based on the LMX theory are a large part of that school's culture.

\section{International Baccalaureate}

There is much research surrounding the International Baccalaureate (IB) Program, but little in the way of school culture. This section of scholarly review will give a brief overview of the history of the IB Program, its mission, vision, and values, as well as an overview of the International Baccalaureate Organization's (IBO) four distinct programs. This review will also include specific studies surrounding IB, its implementation, and impact on school systems.

\section{International Baccalaureate Overview and History}

International Baccalaureate (IB) was formed in 1967 after World War II in an effort to provide quality schools and curriculum for the children on European and American diplomats, military, and international business men traveling overseas for years at a time (Mathews \& Hill, 2005). The formation of IB responded to a need for these types of students, creating an international, consistent, and unified curriculum (Connor, 2008). The International Baccalaureate Diploma Program (IBDP) was the first program established in 1968 "to provide a challenging and comprehensive education that would enable students to understand and manage the complexities of our world and provide them with skills and attitudes for taking responsible action for the future" (International 
Baccalaureate Organization, 2017a). In 1970, the first round of IB examinations were given to 29 students (Mathews \& Hill, 2005). Since then, the IB Program has continued to grow and prosper. As of March 2017, there are 6,068 IB programs worldwide across 4,655 schools. Sixty percent of these schools are in the Americas, with 1808 in the United States alone (International Baccalaureate Organization, 2017b). IB continues to gain popularity in the US as it has more IB schools than any other nation.

\section{International Baccalaureate Mission, Values, and Philosophy}

According to their website, IB states "education is an act of hope in the face of an always-uncertain future. An IB education calls forth the very best in students and educators alike" (International Baccalaureate Organization, 2017c). IBO's mission and values center around rigorous academics and assessment, international mindedness, and life-long learning. The IB Mission Statement states:

The International Baccalaureate aims to develop inquiring, knowledgeable and caring young people who help to create a better and more peaceful world through intercultural understanding and respect. To this end the organization works with schools, governments and international organizations to develop challenging programs of international education and rigorous assessment. These programs encourage students across the world to become active, compassionate and lifelong learners who understand that other people, with their differences, can also be right. (International Baccalaureate Organization, 2017c)

IBO identified 10 traits every IB learner should strive to attain. IB calls this the learner profile. The learner profile claims "these attributes, and other like them, can help individuals and groups become responsible members of local, national and global 
communities" (International Baccalaureate, Learner Profile, 2017e). The ten traits listed in the learner profile are as follows: (a) inquirers, (b) knowledgeable, (c) thinkers, (d) communicators, (e) principled, (f) open-minded, (g) caring, (h) risk-takers, (i) balanced, and (j) reflective (International Baccalaureate Organization, 2017e).

\section{The Four IB Programs}

The IBO has divided into four separate programs, all of them aiming toward different student populations, although, the goal of all four programs is similar. "The aim of all IB Programs is to develop internationally minded people who, recognizing their common humanity and shared guardianship of the planet, help to create a better and more peaceful world" (International Baccalaureate Organization, 2017f). All programs within IBO are philosophically aligned with a consistent pedagogy, each centered on developing attributes of the learner profile (International Baccalaureate Organization, 2017g). The programs were meant to be used as a continuance of education, starting with the Primary Years Program, or PYP for the youngest students, ages 3 to 12. Students would then move onto the Middle Years Program, or MYP, for ages 12 to 16. Lastly, students would either move into one of the culminating programs; the Diploma Program or Career Program, both of these for students ages 16 to 19 (Duarte, 2012).

However, in order to be an IB school, the school system is not required to have all

of the IB Programs. Duarte (2012) stated the IBO "does not require schools that intend to establish a DP to first establish either a PYP or MYP as a feeder program, and, in fact, most school districts have only the IBDP” (p. 18). In order to become an IB school, institutions pay fees, go through an application process, as well as several evaluations to meet accreditation requirements. The IBO has many guidelines and assessments that 
must be followed for a school to offer an IB curriculum of any kind (Duarte, 2012;

International Baccalaureate, Programs, 2017g).

Primary years program. The Primary Years Program, or PYP, was first offered in 1997 to students ranging in ages from 3 to 12 . In the United States, this is for students from kindergarten to fifth grade. It is the least prevalent of the four programs, but enrolls all students in all IB courses (Duarte, 2012). This program prepares students for future education in the Middle Years Program by providing a continuity of learning. The PYP program "focuses on the development of the whole child as an inquirer, both within and beyond the classroom” (International Baccalaureate Organization, 2017g).

Middle years program. The Middle Years Program, or MYP, was first offered in 1994 to students ranging in ages from 11 to 16 . In the United States, this is a program for students in grades 6 through 10 (Duarte, 2012). This five-year program prepares students to continue forward in their IB education. They work to make connections between their school curriculum and the real world, "preparing them for success in further study and in life" (International Baccalaureate Organization, 2017g).

Career program. The Career Program, or IBCP, is the last of the four programs to be offered. It became available to students in 2012 and targets students from the ages of 16 to 19 . In the Unites States, this is for students in grades 11 and 12. The program is meant to be a continuance of the MYP program, for students who do not wish to complete the full DP Diploma. This program is considered career-related learning and leads to higher education, apprenticeships, and employment. This framework "incorporates the values of IB into a unique program addressing the needs of students engaged in career-related education” (International Baccalaureate Organization, 2017g). 
Diploma program. The Diploma Program, or IBDP, was the first program offered by IB. It is "considered the capstone of the IB Program and is the most widespread of the IB school programs" (Duarte, 2012, p. 19). It targets students ages 16 to 19 as a program to be completed after transitioning from MYP. For the United States, this is for students in grades 11 and 12 (Duarte, 2012). This program has multiple assessments and is respected by leading universities across the globe. It was "established to provide students with a balanced education, facilitate geographic and cultural mobility, and to promote international understanding" (International Baccalaureate Organization, 2017g).

\section{International Baccalaureate Implementation in the United States}

IB has grown rapidly in the last thirty years and has moved from international schools to the United States, including public schools (Bunnell, 2009). According to Conner (2008) in his article, From international schools to inner city schools, "The IBDP is currently offered in 125 countries, but it has proved especially popular in the United States. In the last 35 years, more than 564 American high school have adopted the comprehensive 2-year curriculum" (p. 323).

IB is a highly rigorous academic and college preparatory program and has been implemented in the United States for many reasons, but one of those seems to be to try to turn around otherwise struggling school systems. According to Mayer (2008), certain federal incentives and other standards set forth have "prompted struggling urban school districts across the country to introduce rigorous curriculum like...International Baccalaureate (IB) Programs to help raise students' academic performance” (p. 202). Although many IB Programs are implemented in advantaged communities, more recently schools that serve socioeconomically disadvantaged students have begun to implement 
the IB Program as a type of reform. The article goes on to state that there is little evidence to justify this kind of reform to help academic achievement in students of color and low socio-economic status (SES) (Mayer, 2008).

\section{Existing Studies on the IB program and Their Effect on School Culture}

As previously mentioned, IB has been established in urban and low performing school settings because of prestige and rigor (Connor, 2008; Mathews \& Hill, 2005). According to one survey, $70 \%$ of the public schools in the United States who adopted IB curriculum did so to improve academic standards (Bunnell, 2009). However, there is little research that examines the effects of the implementation of IB on the school culture or any area outside of student achievement. In fact, one article even stated "there is a surprising paucity of literature regarding the IBDP" (Bunnell, 2008, p. 411). Studies that do speak to this specific topic are included in subsequent paragraphs.

Studies have discovered IB can have a positive impact on schools and their culture (Duarte, 2012; Mayer, 2008; McMaster, 2015). Stillisano et. al (2011) explained these positive impacts and benefits found in school settings range from improved professional practice, instructional focus on higher level thinking and learning, cultural awareness, and relevance of student learning. Duarte (2012) mentioned benefits such as higher GPA, increased school pride, better instructional techniques by teachers, and a better community outlook on the school.

However, other sources have mentioned there are groups within the United States that are not proponents of the IB program. Some have even gone so far as to call IB unAmerican and that its implementation has created a culture war (Bunnell, 2008, 2009). Drake (2004) warned of the potential for cultural dissonance, while Hill (2007) stated 
"international education has often been described as elitist...a sense of exclusiveness lingers on" (p. 247). A university in England even "denounced the IB Programs as elitist and divisive" (Bunnell, 2008, p. 420).

Negative outcomes, as found by Stillisano et. al (2011), were described as recruitment and retention of staff, balancing the IB philosophy and accountability requirements, and bureaucracy and lack of district support. Other authors such as Duarte (2008) cited areas of privilege and entitlement were the negative impacts of IB on school culture. He stated students who were involved in the IB Program had both earned privileges and entitled privileges that non-IB students did not receive, such as priority scheduling and open-door policies with administration and counselors. "Earned IB privileges are those recognitions given to the IB students by virtue of their high academic standards and achievements" (Duarte, 2008, p. 98). Duarte (2008) also shared how the IB coordinator described the impact IB had on school culture. "The IB students create their own value. The teachers recognize the kids are taking the most rigorous classes available, and the faculty respects those kids" (p. 99). This same study found that a lot of those interviewed felt there was a significant difference between IB students and non-IB students. The principal was quoted as saying IB students "were different because they are smarter than their peers, and it was their intelligence and drive which drew them to becoming IB students" (Duarte, 2008, p. 100). Another teacher within this study mentioned that "the IBDP garnered a disproportionate amount of attention on campus" (Duarte, 2008, p. 123). 


\section{Summary of IB Program and Existing Research}

The IB Program is a long standing international program founded around World War II with a rigorous college preparatory curriculum. It started as an International Program, but has recently grown as an option for public schools within the United States. There are different branches to the IB organization including the Primary Years Program, Middle Years Program, the Career Path Program, and the Diploma Program.

Existing research shows a trend of urban and low performing schools adopting the IB Program into their buildings to help improve academic standards (Bunnell, 2009). However, there is little existing research to inform how school culture has changed, or not, since the implementation of IB (Bunnell, 2008). The current research that does exist gives both positive and negative outcomes for implementing IB. Positive outcomes include higher GPA, increased school pride, better instructional techniques by teachers, and a better community outlook on the school. Negative outcomes that have been cited by existing research include areas such as privilege and entitlement (Duarte, 2012).

\section{Overall Summary}

As seen above, studies have found there are both positive and negative impacts in school settings that implement the IB Program (Bunnell, 2008, 2009; Cox, 2016; Drake, 2004; Duarte, 2012; Hill, 2007; Mayer, 2008; McMaster, 2015; Stillisano et. al, 2001). Cox (2016) stated, "IB can create a special context for students that can either be beneficial or detrimental" (p.19). She goes on to share that "There is little doubt there are merits to the IB program; however, there are serious problems associated with access and successful navigation of the program" (p. 15). While studies list both positive and negative effects, the benefits seem to surround student achievement areas such as college 
readiness and test scores, while negative impacts seem to surround other areas such as effects on culture and access for students and staff alike.

When the implementation of IB is meshed with critical theory and LMX theory while examining school culture, the question becomes, are school leaders essentially helping to reinforce or even create these "in-groups" and "out-groups" within a school culture, or are they reinforcing a dual culture within a school unintentionally? Based on previous research (Bunnell, 2008, 2009; Cox, 2016; Drake, 2004; Duarte, 2012; Hill, 2007; Mayer, 2008; McMaster, 2015; Stillisano et. al, 2001) it is possible implementing IB into an already established school has both positive and negative consequences on school culture. Central High School is no different. "The bottom line for leaders is that if they do not become conscious of the cultures in which they are embedded, those cultures will manage them. Cultural understanding is desirable for all of us, but it is essential to leaders if they are to lead" (Schein, 2005, p. 366). 
Section Four-Contribution to Practice 


\section{Dissemination of Practitioner Contribution}

Who - I shared results with the Central IB Program professional development group. This group meets every Friday morning during the school year for 45 minutes to discuss anything and everything pertaining to the IB Program at Central High School. This might include problems or issues that have come up, fostering growth, end of the year IB testing and evaluation, fostering new programs such as IBCP, and growing the MYP program. This group includes 5 counselors (including the IBCP and IBDP counselor), 2 IB teachers, the IBCP coordinator, the IBDP coordinator, and the MYP coordinator for a total of 10 people. This also includes any administrator that happens to check in on the group on Friday mornings.

When - I shared my results with this professional development group who acts more like a steering committee for the IB Program at Central on a Friday morning during our professional development time. I requested the full 45 minutes that morning be dedicated to reviewing my dissertation, data results, and any implications or discussion points for the future of IB at Central. This included a time to answer questions.

What - The following Executive Summary and Presentation Slides were presented to the Leadership/Administration team as well as the IB Professional Development Group. 


\section{Executive Summary-Tale of Two Schools: A Case Study of Culture in a High School with an International Baccalaureate Program}

\section{Statement of Problem}

There may be an "IB" group and a "Non-IB" group that has been created within Central High School with students and staff alike. The LMX theory would call this the "in-group" and the "out-group" respectively (Northouse, 2016). The problem it may have created is a fragmented school culture of sorts, one with seemingly a positive connotation and one with a seemingly negative connotation.

\section{Purpose of Study}

The purpose of this study was to research the implementation of the International Baccalaureate program in an otherwise established school system and its influence on school culture. School leaders have a responsibility to help create a positive identity, image, and brand, where all students can be successful and have a positive educational experience.

\section{Theoretical Framework}

Critical Theory - unequal creation of power relations, challenging "truths" created by dominate groups (Merriam \& Bierema, 2014)

LMX Theory - Creation of "in-groups" and "outgroups" (Northouse, 2016)

Organizational Culture - points us to phenomena below the surface, powerful in their impact but invisible (Schein, 2005, 2010) Pillars - language, norms and rules, values and beliefs, symbols and artifacts.

- Phenomenological Case Study - qualitative

\section{Design of the Study}

- Participants - teachers at Central High School and recent Central graduates

- Data Collection Tools - online survey for teachers and students, artifact and document collection, classroom observations

- Data Analysis - Open coding, Axial Coding, and Analytical coding all used to achieve "data triangulation" and "data saturation" to help support case study findings (Creswell, 2016; Merriam \& Tisdell, 2016; Yin, 2016)

\section{Research Questions}

- Based on staff and student perceptions, What is the current culture at Central High School?

- Based on staff and student perceptions, What is the role of International Baccalaureate Program in that culture?

\begin{tabular}{ll}
\multicolumn{1}{c|}{ Findings RQ1 } \\
- & Culture at CHS Celebrates Diversity \\
- & Culture at CHS Honors History \\
- & Culture at CHS is Superficially United \\
- & Culture at CHS is Deeply Divided \\
- & IB at CHS Attracts Diversity \\
- IB at CHS Promotes Inclusion & IB at CHS Facilitate Division
\end{tabular}

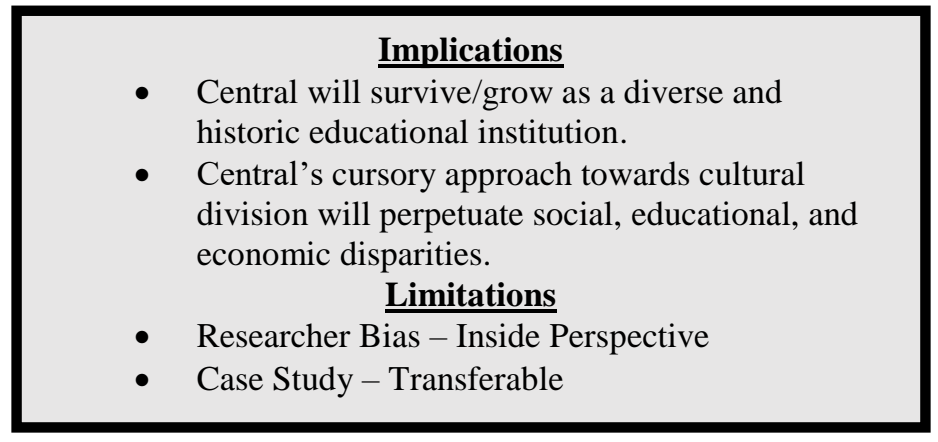

\section{Recommendations}

- Acknowledge an issue to address of a culturally divided school stemming around IB

- Analyze processes, policies, and positions with unbiased, external consultant

- Continue promoting unity

- Make an authentic and applicable change 


\section{Presentation Slides}
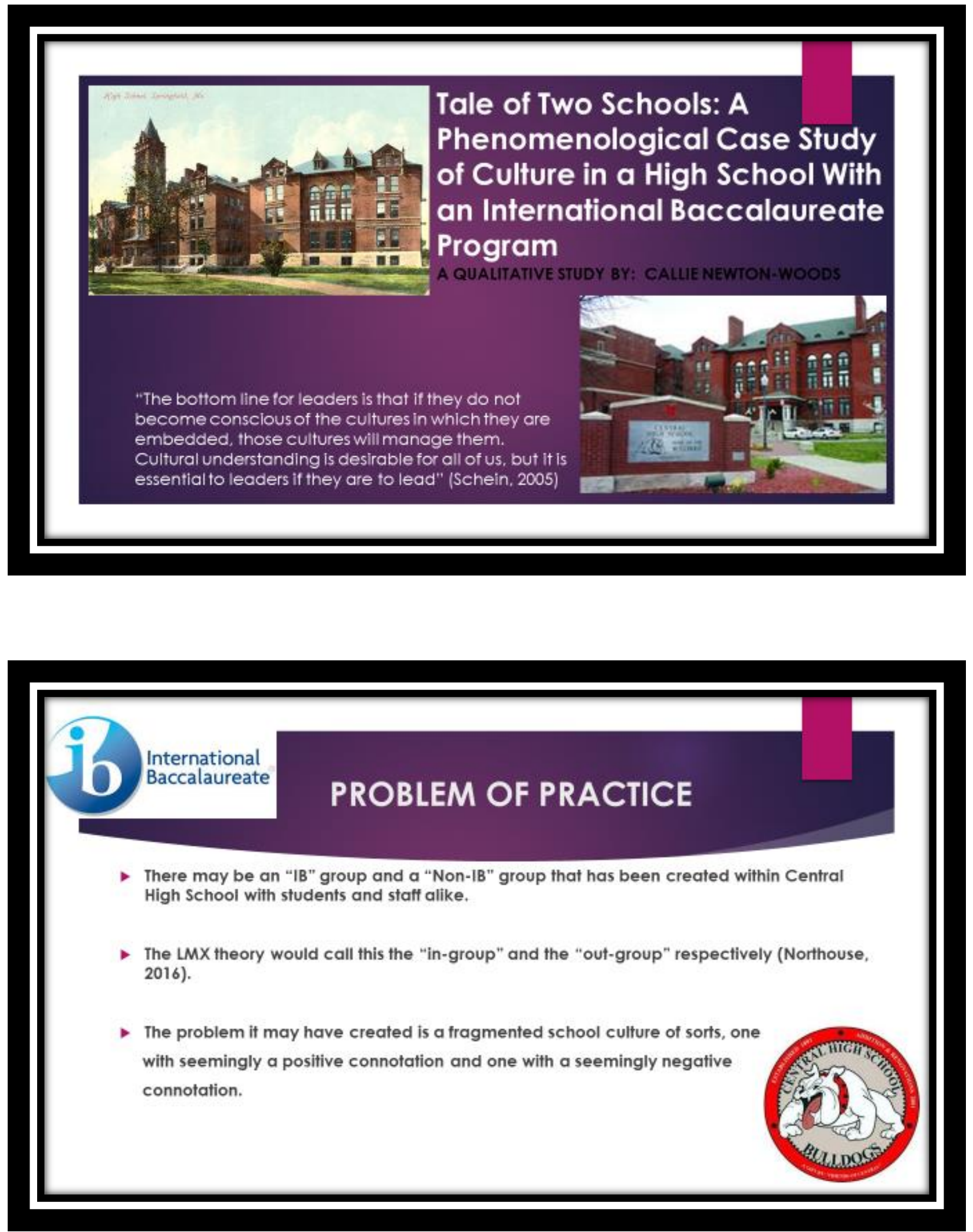


\section{PURPOSE AND SIGNIFICANCE OF STUDY}

- The purpose of this study was to research the implementation of the International Baccalaureate program in an otherwise established school system and its effects on school culture.

- School leaders have a responsibility to their school culture; to help create a positive identity, image, and brand, where all students can be successful and have a positive educational experience.

\section{THEORETICAL FRAMEWORK}

\section{Organizational Culture}

- points us to phenomena below the surface, powerful in their impact but invisible (Schein, 2005, 2010).

- "Glue" and "stuff" that hold organizations together (Manning, 2013)

- "The way we do things around here" (Deal and Kennedy, 1982)

- Schein (2010) defined culture as "a pattern of shared basic assumptions learned by a group as it solved is problems of external adaptation and internal integration...to be taught to new members as the correct way to perceive, think, and feel" (p. 18).

- Pillars - language, norms and rules, values and beliefs, symbols and artifacts. 


\section{THEORETICAL FRAMEWORK}

\section{Leader Member Exchange Theory}

- Leaders create dyadic relationships with followers: "in-group" and "out-group" (Lunenburg, 2010; Northouse, 2016).

- In Group - given more latitude in their roles, along with greater responsibilities and rewards.

- Out-Group - outside the inner circle, have less responsibility and rewards, and are controlled by rules and policy

\section{THEORETICAL FRAMEWORK}

\section{Critical Theory}

- (a) examine and critique social conditions,

- (b) challenge "truths" and ideologies set by dominate social groups while examining power relations created within society, and

- (c) emancipate marginalized people groups and eliminate oppression of these people groups

- (Kezar, Carducci, \& Contreras-McGavin, 2006; Merriam \& Bierema, 2014; Merriam \& Tisdell, 2016). 


\section{RESEARCH QUESTIONS}

- Based on staff and student perceptions, what is the current culture at Central High School?

- Based on staff and student perceptions, what is the role of International Baccalaureate Program in that culture?

\section{DESIGN OF STUDY}

- Case Study-qualitative, phenomenological

- Participants -

- Teachers -84 teachers at Central HS = comprehensive and convenient sample (Creswell, 2016; Fink, 2013).

- Teachers at Central range in number of years, what they teach, male or female. etc.

- Graduated students from Central High School = convenient sample

- 10 IB students, 10 non-IB students, 10 students who were in both IB and non-IB classes 


\section{DESIGN OF STUDY}

\section{- Data Collection Tools - SURVEY}

- Online, qualitative survey through Qualtrics for teachers and graduated students

- Why did you choose to be an IB teacher or Non-IB teacher at Central High School?

- Describe what it is like to be an IB Teacher or Non-IB teacher at Central High School

- Describe how teachers act toward IB-students. Describe how teachers act fowards non-IB students.

- Describe the interaction between IB students and non-IB students. Describe the interaction between IB teachers and non-IB teachers.

- Describe how school leaders act towards IB students. Describe how school leaders act towards non-IB students.

- Describe how school leaders act toward IB feachers. Describe how school leaders act towards non-IB teachers.

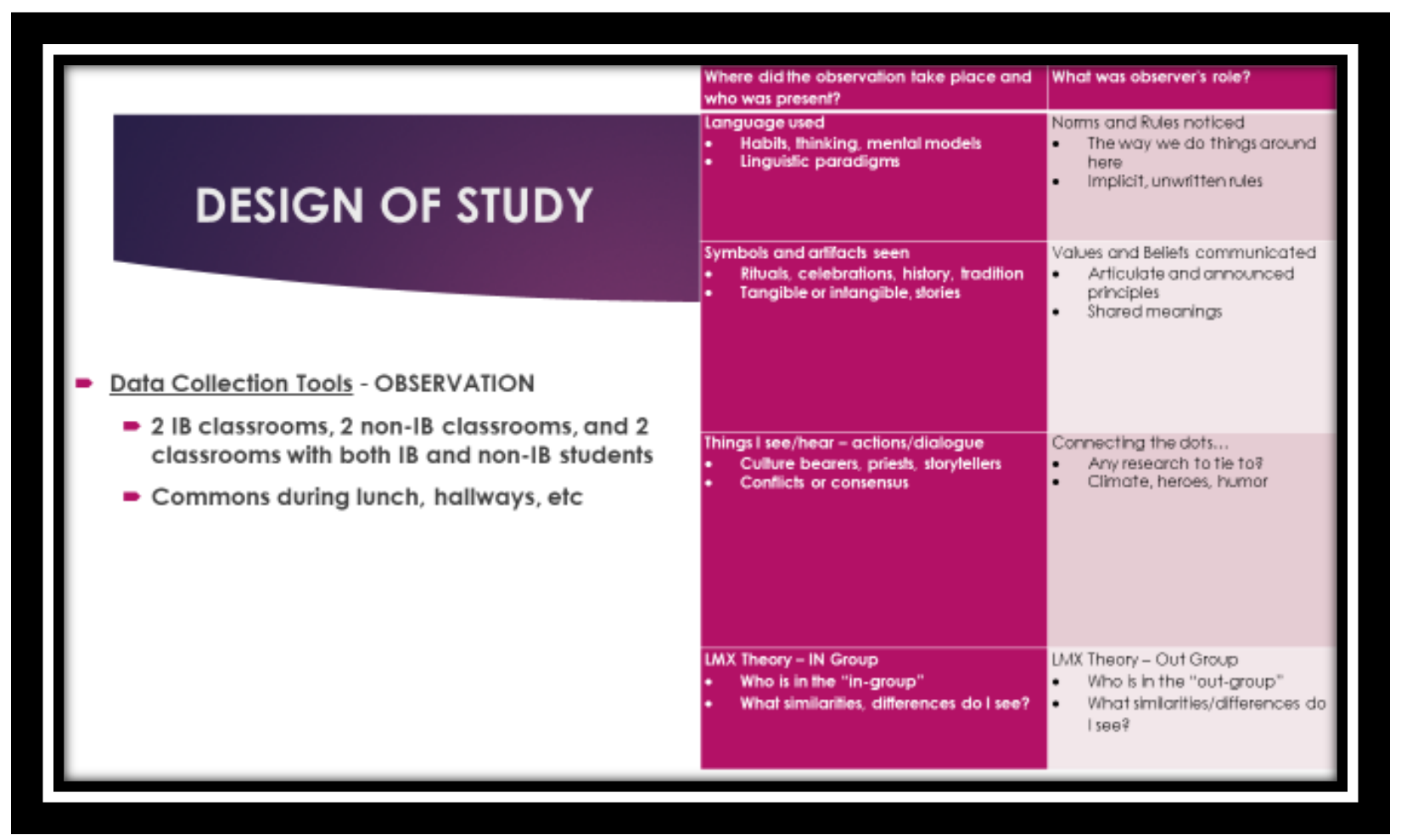




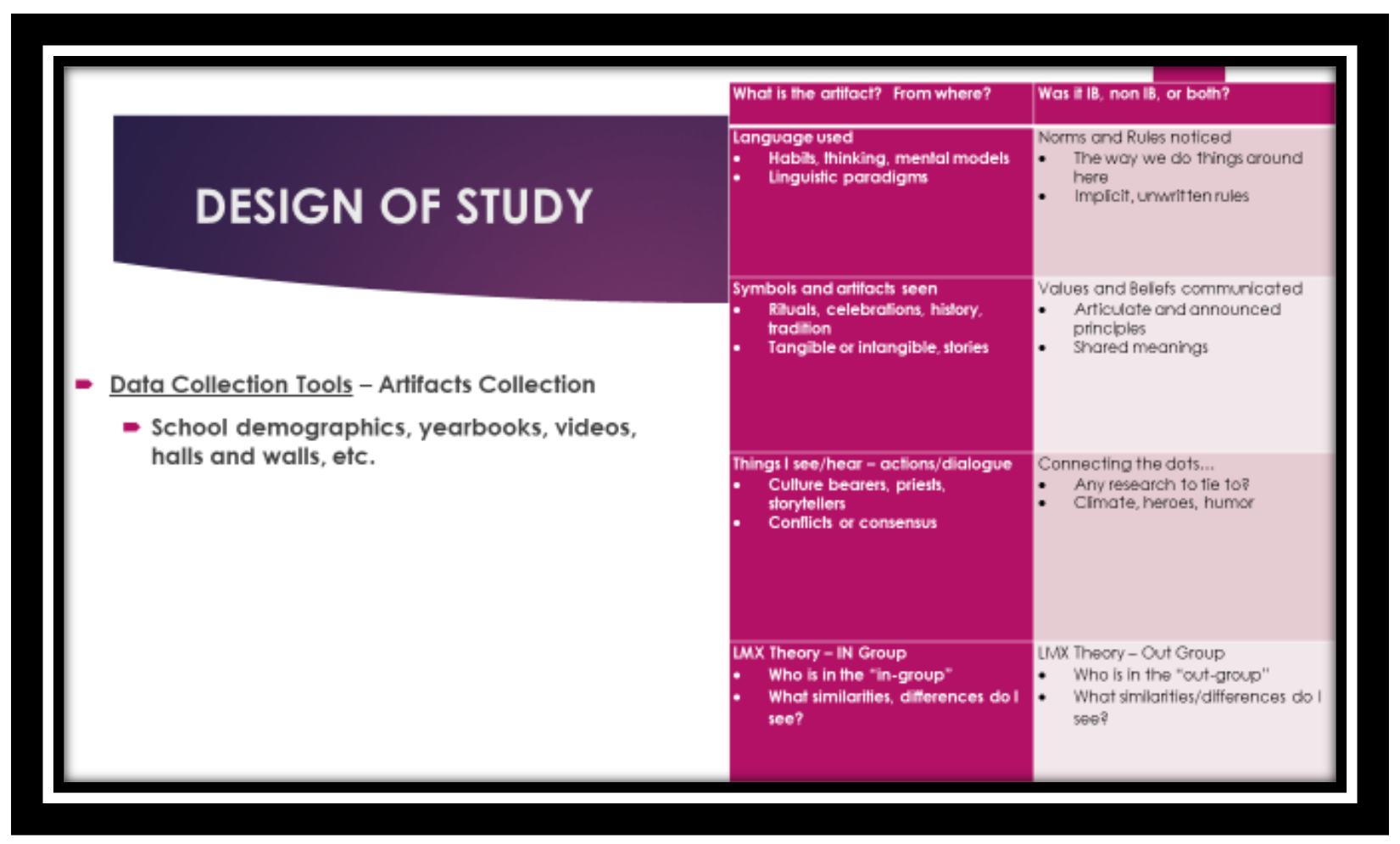

\section{DESIGN OF STUDY}

- Data Analysis

- Open coding, Axial Coding, and Analytical coding all used to achieve "data triangulation" to help support case study findings (Creswell, 2016; Merriam \& Tisdell, 2016: Yin, 2016). 


\section{DESIGN OF STUDY}

- Irustworthiness, Reliability, Transferability, and Bias

- My Role: Insider and participant as observer (Creswell, 2014; Merriam \& Tisdell, 2016)

- One, data triangulation with four different data sources was utilized (Creswell, 2014; Merriam \& Tisdell, 2016; Yin, 2014

- Two, researcher positionality and bias was clearly defined and discussed throughout the research (Creswell, 2014; Merriam \& Tisdell, 2016).

- Three, an audit trail was utilized. "describes in detail how data were collected, how categories were derived, and how decisions were made throughout the inquiry" (Merriam \& Tisdell, 2016, p. 252).

- Four, a peer debriefing and expert review was used to enhance the accuracy of the account and data collected (Creswell, 2014; Merriam \& Tisdell, 2016).

- Five, using a rich, thick description as well as placing actual quotes within the study will increase the validity and transferability of the research (Creswell, 2014; Merriam \& Tisdell, 2016). Having these safeguards in place will help with the study's reliability, as well as its generalizability.

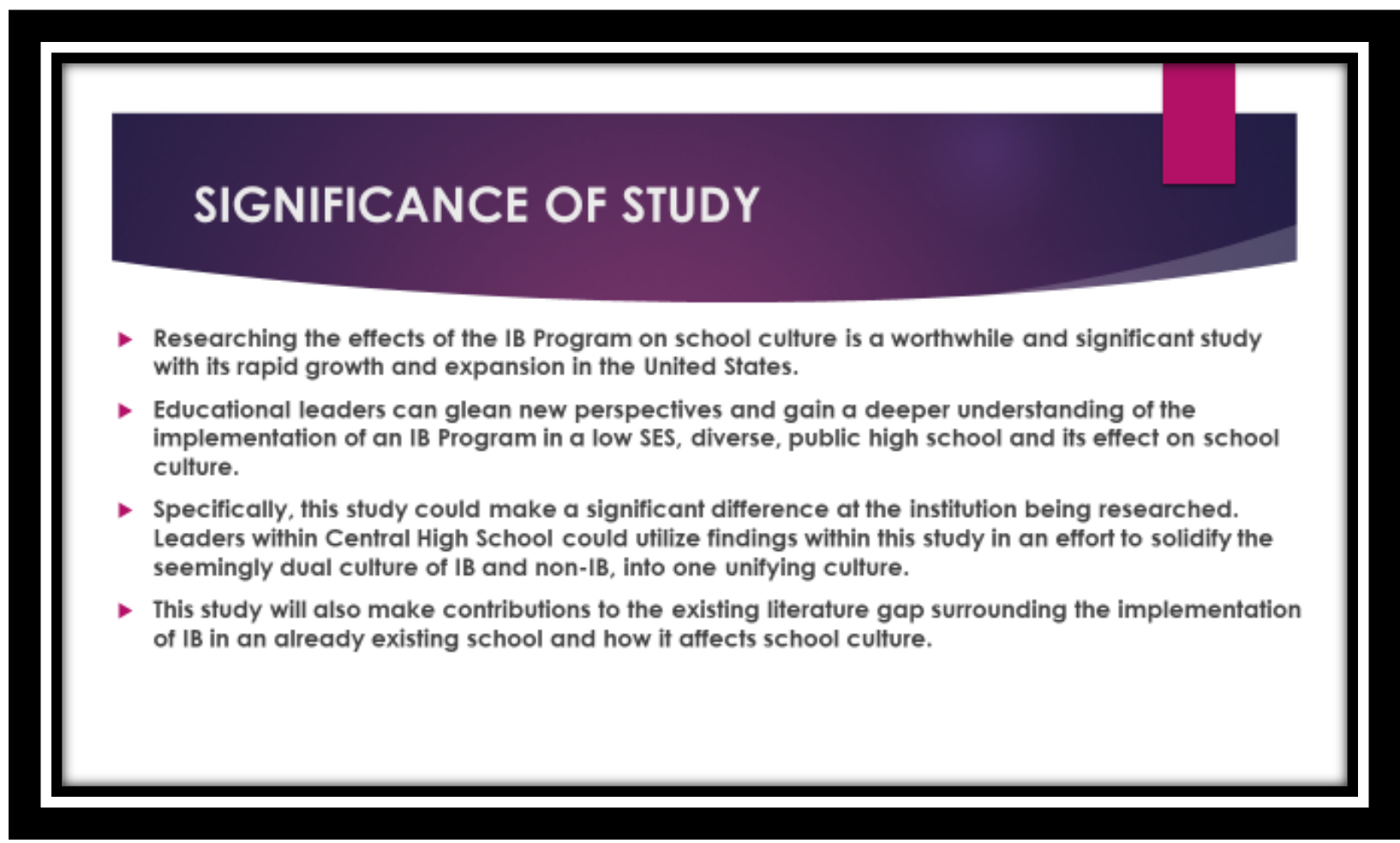




\section{PRACTITIONER SETTING}

- Central High School History

- Built in 1893 - first high school in Springfield, 1950 s - 3,500 enrollment

- 1990s - almost closed down twice, 1996 - IB Program added to Central

- Central High School Current

- 1700-1800 enrollment

- Premier college prep programs in country, National Merit Scholars, highest ACT in district

- Roughly $25 \%$ of student population is involved in IB in some way

- $70 \%$ of Central students are White $-80 \%$ of IB students are White

- $51 \%$ of Central students are on Free and reduced lunch - $18 \%$ of IB students are on F/R lunch

- $13 \%$ of Central students are Black $-2 \%$ of IB student are black

- IB program demographics do not match whole school demographics

\section{PRACTITIONER SETTING}

- Organizational Analysis (Bolman and Deal, 2013).

- Political Frame - lots of vying for position, power, and resources - who gets what because of IB?

- Structural - LOTS of policies, rules, lists of duties on paper - not sure they are communicated well face to face

- Human Resource - low communication and low morale between IB and Non-IB groups

- Symbolic - Through Research

- Leadership Analysis (Northouse, 2016).

- Gender and leadership - 3rd year with a female principal - working through the "can women lead?" question.

- Skills traits approach - Leadership duties divided by talents (5 administrators, 3 IB coordinators, 2 counselors) 


\section{SCHOLARLY REVIEW}

- Organizational/School- 4 Pillars - language, symbols and artifacts, norms and rules, values and beliefs

- Willard Waller (1932): "Schools have a culture that is definitely their own. There are, in the school, complex rituals of personal relationships, a set of folkways, mores, and irrational sanctions, a moral code based upon them

- Barth (2002): "A school's culture has far more influence on life and learning in the schoolhouse than the president of the country, the state department of education, the superintendent, the school board, or even the principal, feachers, and parents can ever have"

- Critical Theory

- Merriam and Tisdell (2016) "critical educational research examines the context where learning takes place, including the larger systems of society, the culture, and institutions that shape educational practice"

- Theoharis (2008): "addressing and eliminating marginalization in schools is a critical component"

- Dantley (2009): "The whole point of critical theoretical thought is not only to unmask those systemic ways in which institutions such as schools marginalize and disenfranchise those deemed to be outside of the

accepted fraditions and classifications, but also to propose an oppositional arrangement of these institutions"

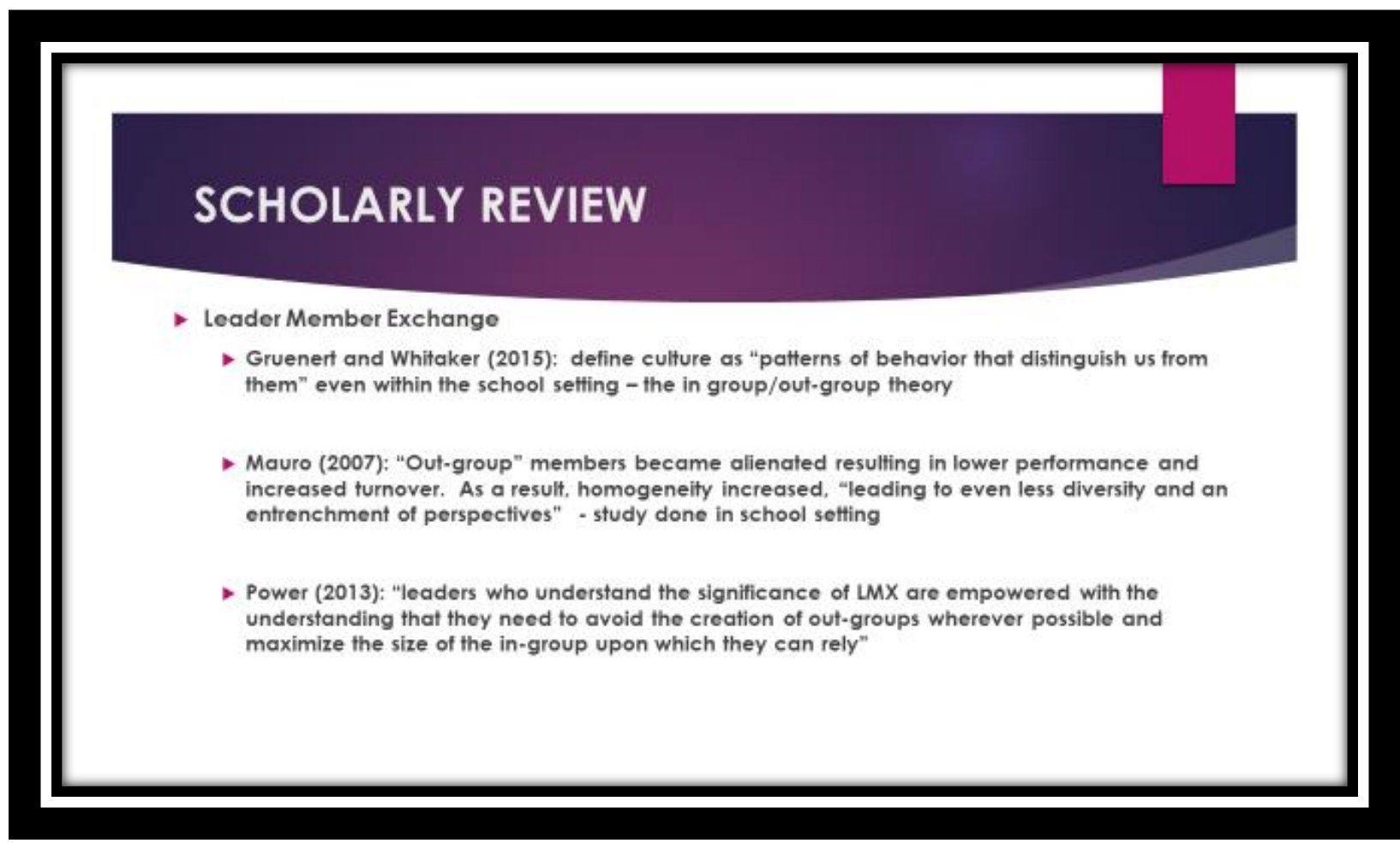




\section{SCHOLARLY REVIEW}

- International Baccalaureate

- Mayer (2008): federal incentives have "prompted struggling urban school districts across the country to introduce rigorous curriculum (IB) Programs to help raise students' academic performance"

- Studies have discovered that IB can have a positive impact on schools and their culture (Duarte, 2012; Mayer, 2008; McMaster, 2015) - improved professional practice, cultural awareness, higher GPA, increased school pride, better instructional techniques by feachers, and a better community outlook on the school.

- Other sources are not proponents of the IB program. Some have even gone so far as to call IB unAmerican and that its implementation has created a culture war (Bunnell, 2008, 2009). - recruitment and staff retention, areas of privilege and entitlement

- A university in England even "denounced the IB Programs as elitist and divisive (Bunnell, 2008, p. 420).

- There is little evidence to justify this kind of reform to help academic achievement in students of color and low socio-economic status (Mayer, 2008).

\section{FINDINGS}

$R Q$ 1: Based on Student and Staff Perception, What is the Current Culture at Central High School?

- Finding One: The culture at Central High School CELEBRATES DIVERSITY.

- Finding Two: The culture at Central High School HONORS HISTORY.

- Finding Three: The culture at Central HIgh School Is SUPERFICIALLY UNITED.

- Finding Four: The culture at Central High School is DEEPLY DIVIDED. 


\section{FINDINGS}

$R Q$ 2: What is the role of international Baccalaureate Program in that culture?

- Finding One: IB at Central High School ATTRACTS DIVERSITY.

- Finding Two: IB Curriculumat Central High School PROMOTES INCLUSION.

- Finding Three: IB at Central HIgh School FACILITATES DIVISION.

\section{RQ 1 - FINDING 1 The Culture at CHS Celebrates Diversity}

RQ 1: Based on Student and Staff Perception, What is the Current Culture at Central High School?

- Student Demographics: Race, nationality, SES, Academic, religion, LGBTQ

- Survey Data:

- "Ilove Central because I get to work with a group of diverse students." -teacher quote

- "Central has the most diversity and I wanted to be in a program with this diversity." -student quote

- Artifact Data: display cases, student work, wall art, commonsflags, hellowall 

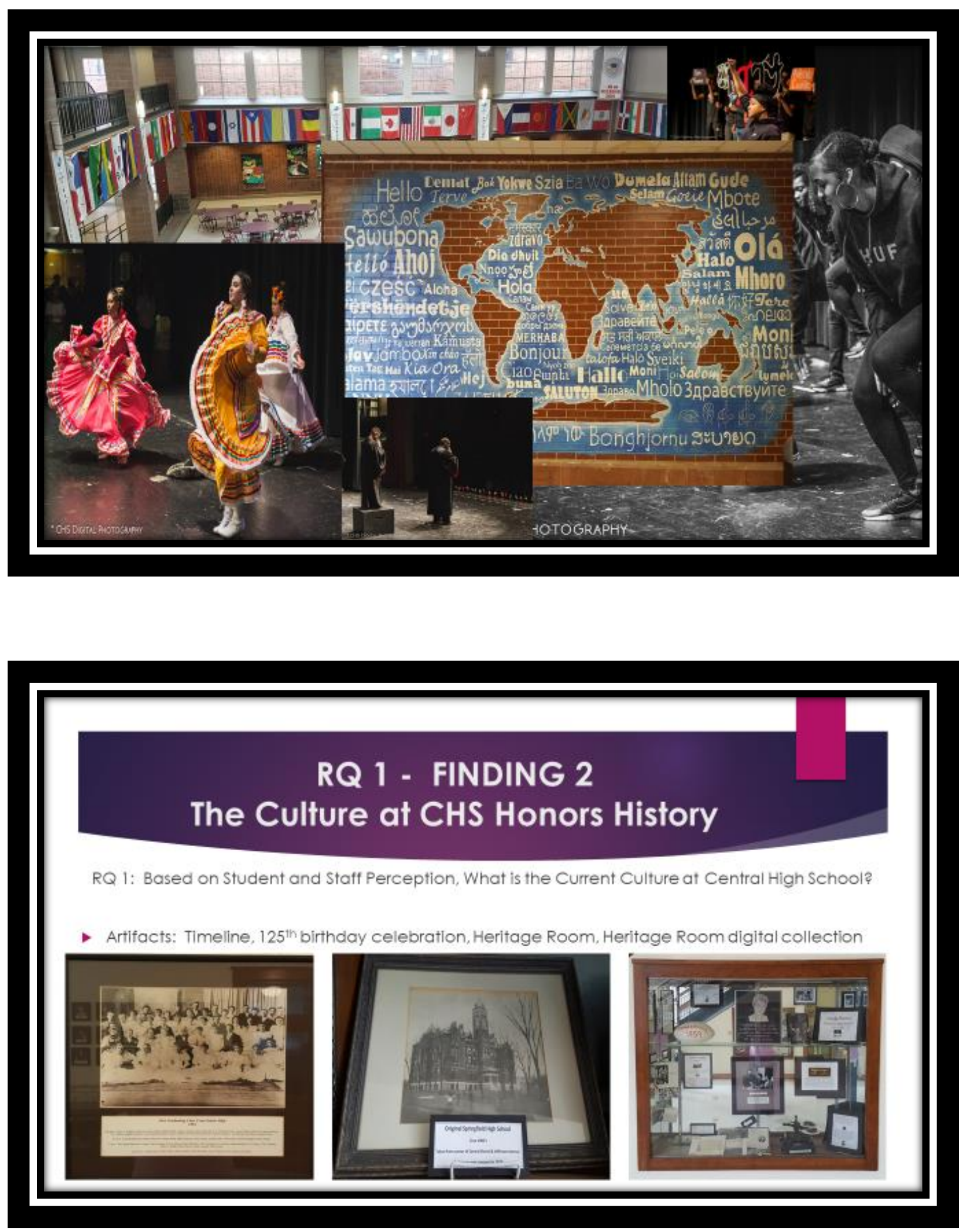


\section{RQ 1 - FINDING 3 The Culture at CHS is Superficially United}

RQ 1: Based on Student and Staff Perception, What is the Current Culture at Central High School?

- Surveys Responses

- "The big thing is we talk about diversity....but we do not truly have diversity - diversity is a word to use because that is the flavor of the month" and "You can't put up posters or make MYP unit plans and make us cohesive" - teacher quotes

- Classroom Observation

- Classroom Assignment and Instructions from teacher. "How inclusive is Central High School? Diverse? Yes. Inclusive? Maybe not. If you walk the entire building you will see diversity, but do you see inclusiveness throughout."

- Artifact Data: Mission statement, trophy cases, displays, etc.

- CHTimes - \#OneCentral Issue - "In particular, one social divide has caught the attention of many students and has dominated conversation regarding \#OneCentral: The divide between IB and Non-IB students. Right now there are two groups almost competing against each other, which is a really negative environment for our school and we want there to be an equal playing fleld" [CHTimes - Vol 103, issue ]

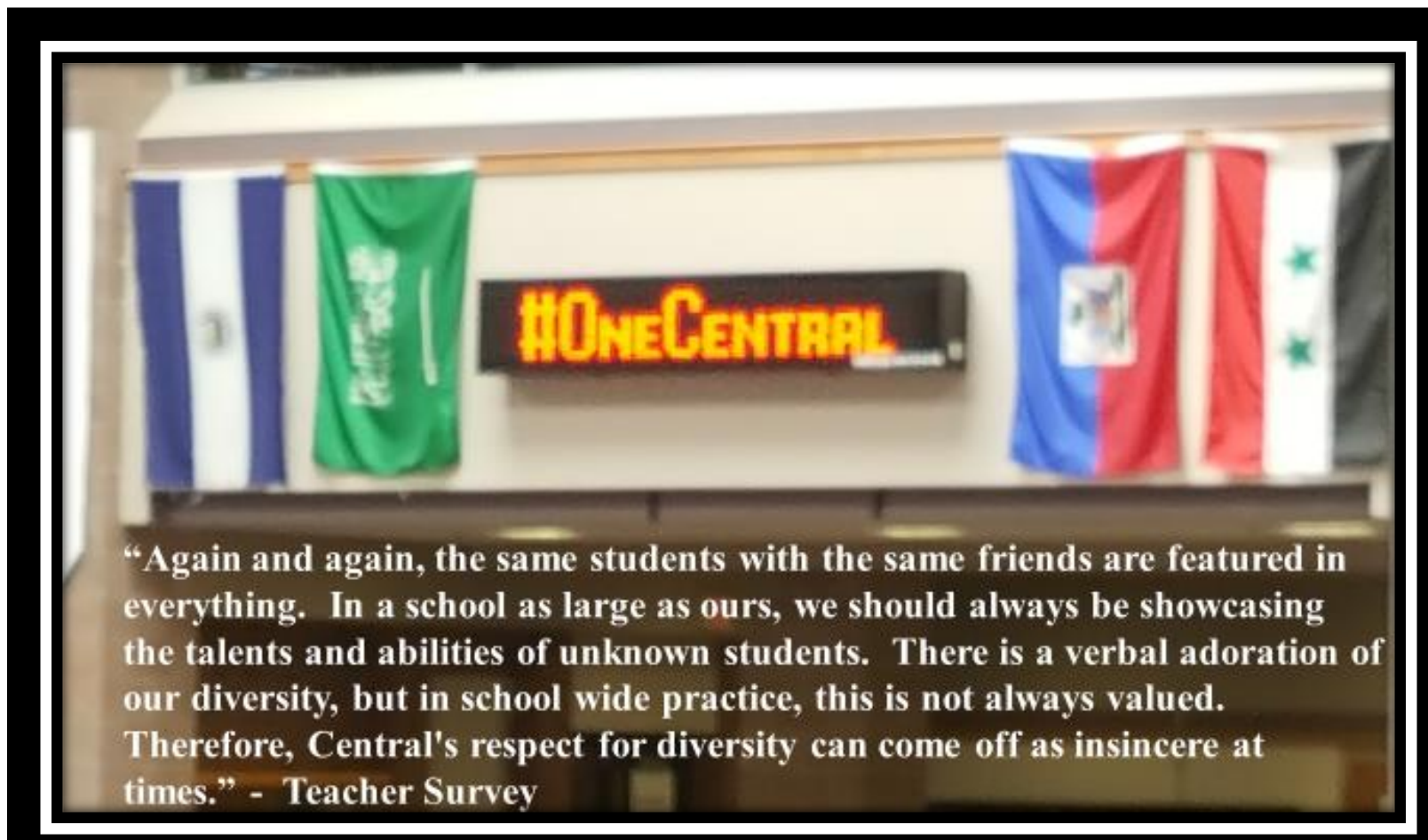




\section{RQ 1 - FINDING 4 The Culture at CHS is Deeply Divided}

RQ 1: Based on Student and Staff Perception, What is the Current Culture at Central High School?

- Artifacts

- Facebook Post - IB vs Non-1B discussion

- SurveyResponses

- "I made the mistake, once, of saying to my traditional LL student that 'we are all IB at Central' and I was nearly burned at the stake. There is a stark divide between the traditional track and the $\mathrm{BB}$ track. This divide continues to decrease as more teachers accept the responsibilities of MYP and the Career Program, but it will never fully disappear" - teacher quote

- "IB creates an atmosphere of some students are more valuable than other students which is toxic for both sides" - student quote

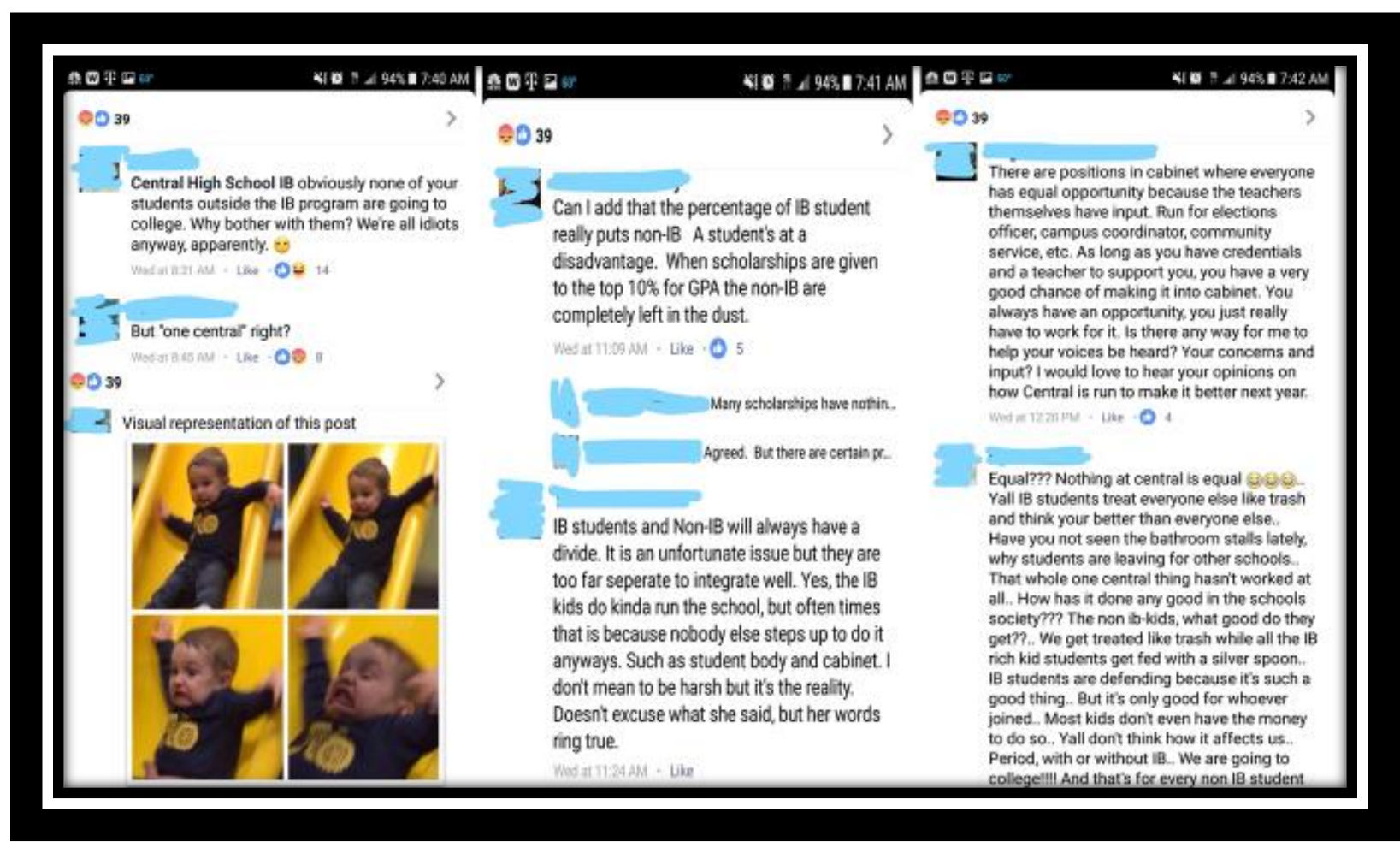




\section{RQ 2 - FINDING 1 IB at CHS Encourages Diversity}

$R Q$ 2: What is the role of International Baccalaureate in that culture?

- Survey Data:

- H loved the diversity and challenge of teaching IB, however, I do think the diversity is difficult to balance to be sure everyone feels attended to." - teacher quote

- "l love the diversity that Central holds within the halls, but the only negative I see that the IB program brings is that IB students are typically in leadership roles for clubs and extra-curriculars. That gives people the idea that IB students are more valuable than non IB" - student quote

- Artifact:

- The IB Mission Statement states the aim of IB is to "develop inquining, knowledgeable and caring young people...to encourage students across the world to become active, compassionate and lifelong leamers who understand that other people, with their differences, can also be right"

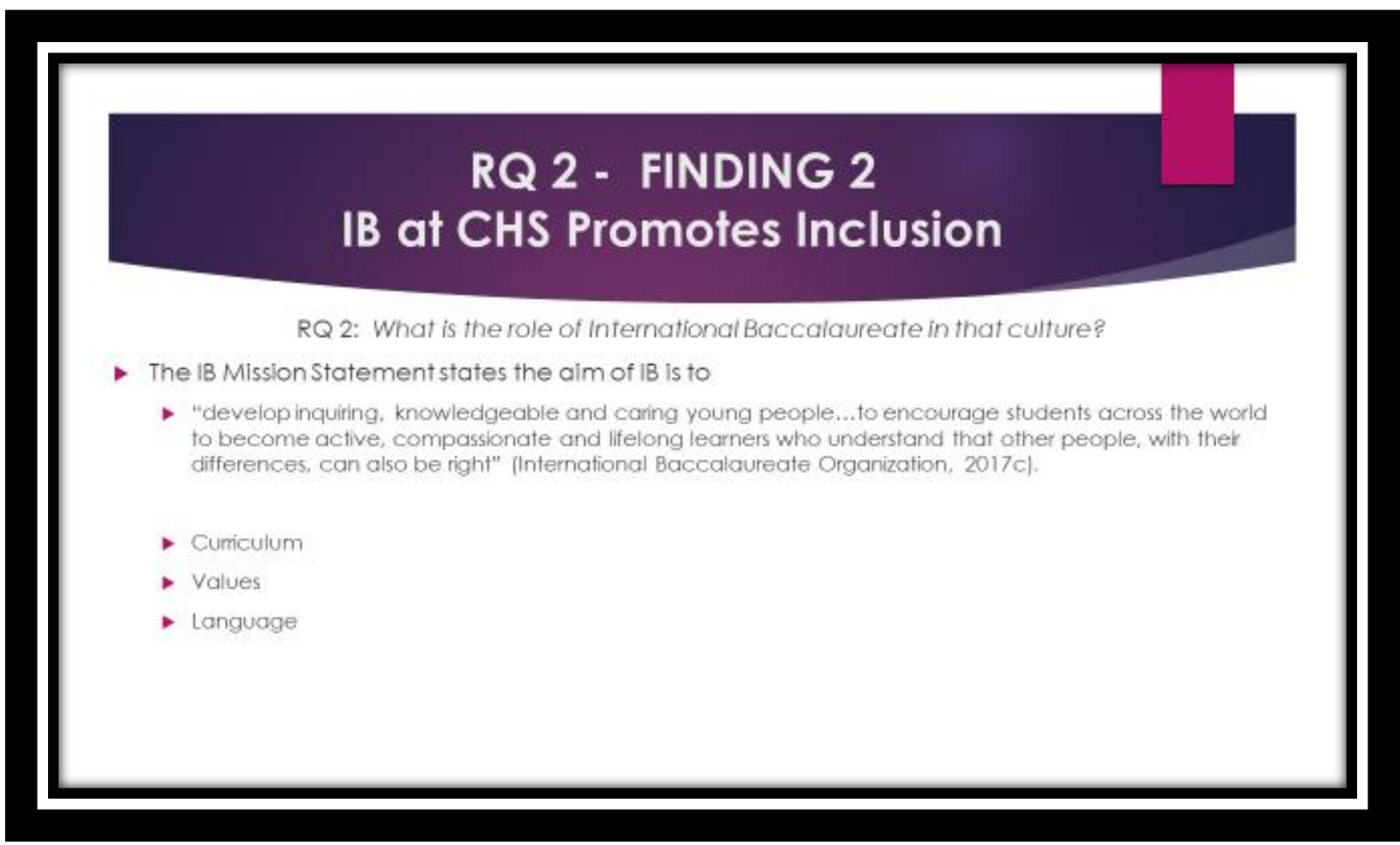




\section{RQ 2 - FINDING 3 IB at CHS Facilitates Division}

$R Q$ 2: What is the role of International Baccalaureate in that culture?

- Survey Data: Most often students and teachers clted different rules, expectations, treatment, and resources for those who are a part of the IB program and for those who are not

- Survey: "IB is a realm where students who are in it are considered more important some-how. IB students are granted forgiveness quickly. There is an assumption of innocence that is not granted to the entire student body" - teacher quote

- Survey: "Most teachers in the bullding recognize the unfair attention most IB students get. Teachers who teach non-IB feel the SILENT STIGMA of not teaching IB. We don't know the lingo, we haven't had the kids in class that everyone in the bullding seems to know and recognize." teacher quote

\section{IMPLICATIONS and LIMITATIONS}

- IMPLICATIONS

- Central will continue to survive, and perhaps even grow, as a diverse and historic educational institution.

- Central's cursory approach towards cultural division will perpetuate social, educational, and economic disparities.

- LIMITATIONS

- Researcher Positionality - Insider Perspective and bias

- Case Study - Transferability 


\section{RECOMMENDATIONS FOR CENTRAL LEADERSHIP}

- One: Acknowledge there is an Issue/Concern to Address

- Agree possibility of a divided culture stemming around $\mathrm{IB}$

- Two: Analyze Processes, Policles, and Positions with an Unbiased, Outside Consultant

- Are these things helping meet the school's mission statement? Why not?

- Three: Continue Promoting Unity

- We are all IB, \#Bulidog nation, Diversity Assembly, etc

- Four: Make an Authentic and Applicable Change

- Commit to extended, on-going, authentic communication between 18 and Non-IB via steering committee

- Actively recruit from more diverse student populations into the 18 program

- Remove the application process for the IB program.

\section{Practitioner Contribution}

Who: IB Program Professional Development Group

- Counselors, IBDP Coordinator, IBCP Coordinator, Lead teachers in IB Program

-When: Friday morning during professional development time - $\mathbf{4 5}$ minutes to an hour

- Documents Presented: PowerPoint, Executive Summary 

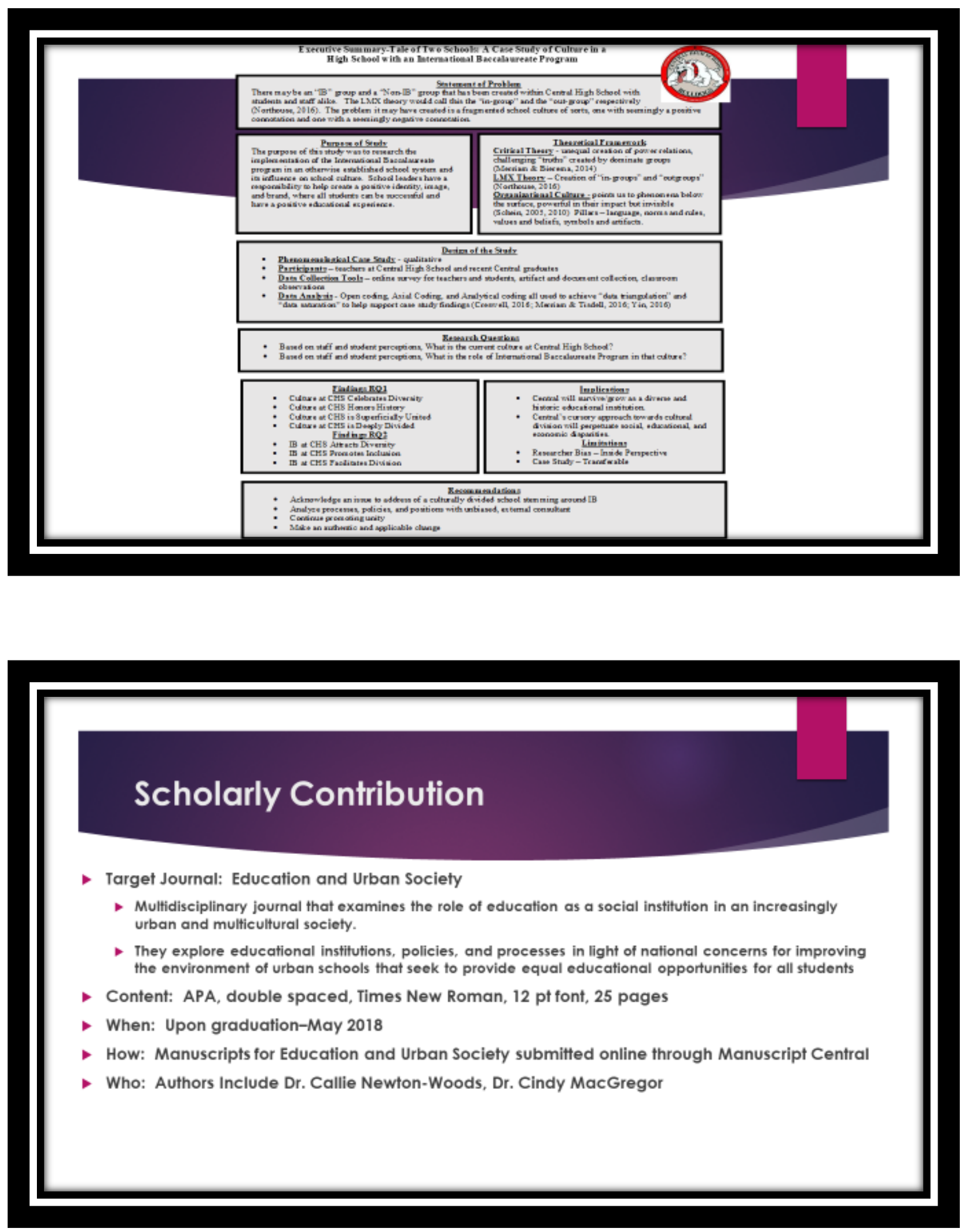


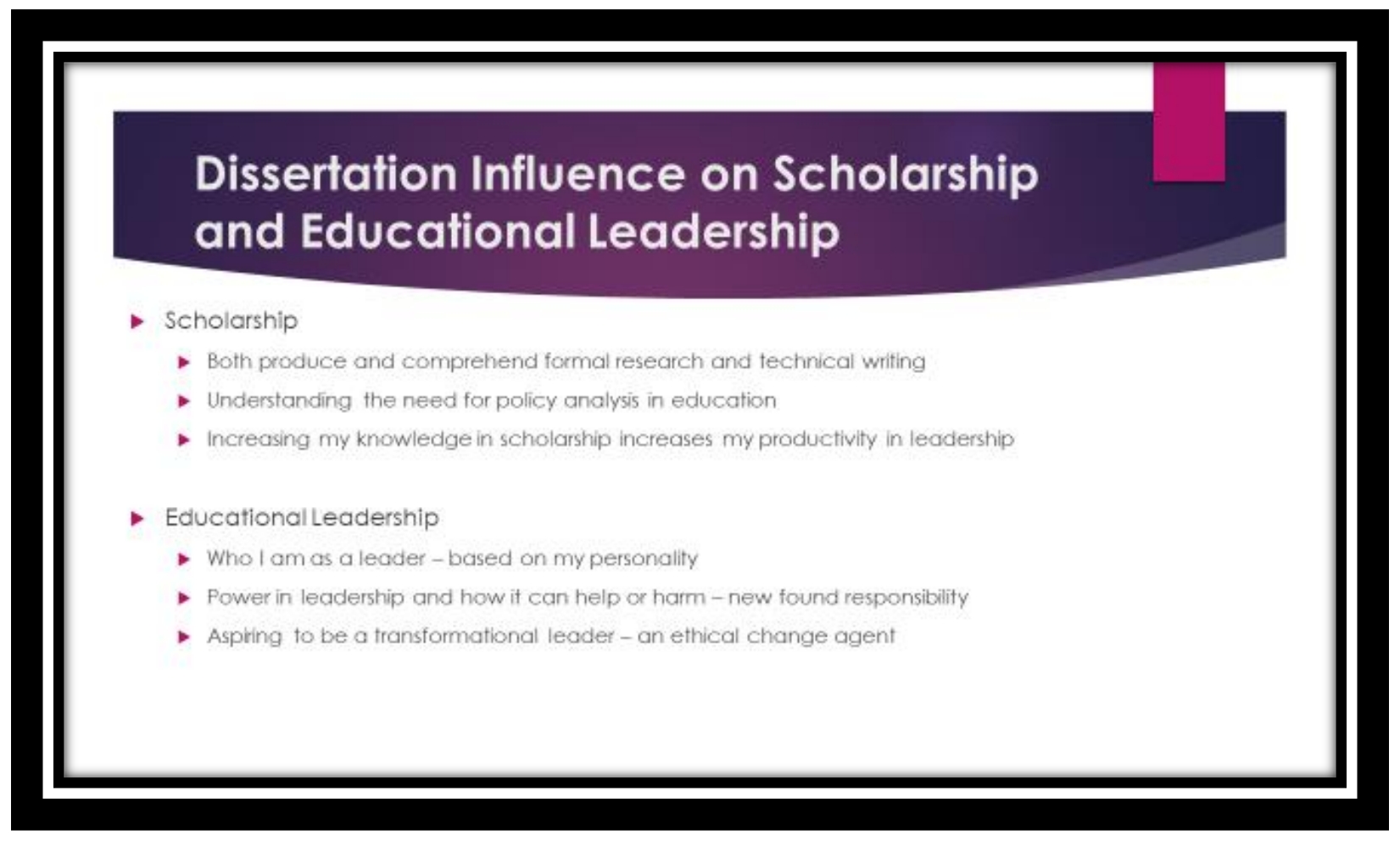


Section Five--Contribution to Scholarship 
TALE OF TWO SCHOOLS:

A PHENOMENOLOGICAL CASE STUDY OF CULUTRE IN A HIGH SCHOOL WITH AN INTERNATIONAL BACCALEAUREATE PROGRAM

Authorship: Callie Newton-Woods, Dr. Cynthia MacGregor, and Dr. Kim Finch Acknowledgements to Dr. Bill Agnew and Dr. Michael Hudson

To be submitted to Education and Urban Society

There is no required word count but typical text is around 25 pages

(without title page, 150-250 word abstract, 4-5 key words, references, or appendices). 


\begin{abstract}
International Baccalaureate (IB), a highly rigorous academic and college preparatory program, has sometimes been implemented to turn around otherwise struggling school systems. Little is known about the impact on school culture from the implementation of IB in a low-achieving, high poverty school through the lens of critical theory and leader-member exchange theory. The purpose of this study was to gain teacher and student perspectives on the culture of a high school twenty years after the introduction of IB. The research questions that guided this study were as follows: Based on staff and student perceptions, what is the current culture at Central High School? What is the role of International Baccalaureate in that culture? Findings indicated that the culture of this high school was diverse, historic, superficially unified, and deeply divided. Findings further indicated that IB both encouraged diversity within the school, as well as facilitated division. Implications from this research state Central High School will continue to survive, and perhaps even grow, as a diverse and historic educational institution; however, the approach used towards cultural division will continue to perpetuate social, educational, and economic disparities within that school.
\end{abstract}

(word count: 186)

\title{
Key Words
}

Critical theory, Leader-Member Exchange Theory, International Baccalaureate, Culture/School Culture, Marginalized students 
In 1983 the National Commission on Excellence in Education released its report, A Nation at Risk, warning people of mediocrity in American school systems. The effects of this report are still evident 30 years later and according to some, evoked a crisis in the field of public education by stating it was failing and in need of reviving (Alliance for Excellent Education, 2009; Matthews \& Hill, 2005; Metha, 2015; Schlechty, 1997; Wilkinson \& Hayden, 2010). The response to this perceived problem is often to introduce an outside program, a transformative force to change school culture.

Culture exists in all places, whether in nations, organizations, homes, or in schools (Bolman \& Deal, 2013; Deal \& Peterson, 2016; Schein, 2005, 2010). School culture is vastly important because it dictates, at times unspoken, how things are done in an educational setting (Barth, 2002). It is imperative as educational leaders we become familiar with what culture is and how it can affect a school system. In their book, School culture rewired: How to define, asses, and transform it, Gruenert and Whitaker (2015) mimic this thought and further extend it stating that "culture is both a survival mechanism and a framework for solving problems" (p. 4). If culture is both how we survive and solve problems, questions should be asked about school culture in general and how a particular school culture came to be.

According to critical theory, unequal power relations are created in every cultural setting, no matter if it is nationally, organizationally, or in a school. This difference in power will always produce the haves and the have-nots (Merriam \& Bierema, 2014). Stratification of power has been created habitually in educational settings, school culture, and student achievement levels. Marginalized groups within the school system is no novel idea. Similarly, the leader-member exchange (LMX) theory states that based on 
leader and follower exchanges, there is always an "in-group" and an "out-group" created within an organization, or in this case, a school setting (Northouse, 2016). This should communicate to leaders in the educational system that there is always a culture within the school, and often, this culture can create an "us and them" mentally.

Within recent years, International Baccalaureate (IB), a highly rigorous academic and college preparatory program, has been implemented in the United States for many reasons, but one of those seems to be to try to turn around otherwise struggling school systems. Studies have discovered that IB can have a positive impact on schools and their culture (Connor, 2008; Drake, 2004; Duarte, 2012; Mayer, 2008; McMaster, 2015). Other sources have mentioned there are groups within the United States that are not proponents of the IB program, calling it un-American because it has created a culture war (Bunnell, 2008, 2009). Based on previous research (Bunnell, 2008, 2009; Duarte, 2012; IBO, 2017; Mayer, 2008; McMaster; 2015) it is possible that implementing IB into an already established school has both positive and negative effects on school culture. This begs the questions, what is school culture and how does IB affect it?

This research is an investigation of such a phenomenon. In the case of Central High School, the International Baccalaureate program was introduced and placed in a low socio-economic status (SES), rather diverse city school that was in danger of closing, in the hopes of making some positive changes. It is important to look at how IB influences school culture, not simply school achievement, and it is equally important that school leaders research the school culture with a willingness to list both positive and negative outcomes. While evidence of positive effects of IB in public schools in the United States have been established, there is very little investigation on the converse or negative effects 
of the implementation of IB on school culture. What specific problems it may or may not be creating within the school has yet to be seen or studied. This research would help to address this problem in practice as well as address the existing gap in literature.

Within the parameters of this study, I will be examining the IB program and its implementation and influence on school culture in one particular case study, a diverse high school in Springfield, MO. The guiding research questions for this study are as follows: Based on staff and student perceptions, what is the current culture at Central High School and what is the role of International Baccalaureate in that culture?

\section{Literature Review}

There will be four specific areas of scholarly review that will inform this research; they are as follows: (a) organizational culture as it applies to school culture; (b) critical theory as it applies to marginalized groups within a school setting; (c) leader-member exchange theory as it applies to creating "in-groups" and "out-groups" within a school setting; and (d) a brief overview of the International Baccalaureate program and specific studies surrounding IB, and its implementation into other school settings.

\section{Organizational/School Culture}

Defining culture can be subjective and abstract. Culture within a school system carries the same nuances other organizational cultures carry; therefore, school culture will take on much the same definition of organizational culture. Deal and Peterson (2009) stated school culture is the "glue, the hope, and the faith that hold people together" (p. 5) and the "unofficial pattern that seems to permeate everything" (p. 5). School culture is vastly important because it dictates operational rules in an educational setting (Barth, 2002). 
When examining and evaluating an already established culture, it is necessary to have a list of "look-fors" or "pillars" when collecting data (Bolman \&Deal, 2013; Deal \& Kennedy, 1982; Deal \& Peterson, 2009, 2016; Gruenert \& Whitaker, 2015; Manning, 2013; Martin, 2002; Schein, 2005, 2010). Four pillars of culture will be utilized for data collection: (a) shared values and beliefs, (b) norms and rules, (c) symbols and artifacts, and (d) language.

Shared values and beliefs. Values and beliefs define what an organization stands for while also sharing qualities found important by a group of people. They can be both publicly announced or privately followed, but they help to convey an identity, including aspects such as a mission statement, working philosophy, or vision for the organization (Bolman \& Deal, 2013; Schein, 2005, 2010).

Norms and rules. Norms and rules can be spoken and written, or they can be implicit and unwritten. Group norms can also be either formal or informal, stating "the way we do things around here" (Bolman \& Deal, 2013; Schein, 2005, 2010). Often the norms are considered the "unwritten rules for getting along in the organization, "the ropes' that a newcomer must learn to become an accepted member" (Schein, 2010, p. 15).

Symbols and artifacts. Symbols and artifacts are the tangible pieces of an organization. According to Bolman and Deal (2013), "symbols carry powerful intellectual and emotional messages; they speak to both the mind and the heart" (p. 243). Simply put, "an organization's culture is revealed and communicated through its symbols" (Bolman \& Deal, 2013, p. 248).

Language. Language is a shared cognitive frame guiding members of the group in the socialization process (Schein, 2010). The language within a culture helps to clarify 
the boundaries between those who are a part of the culture and those who are not. Language within a school setting can be both formal and informal, and can come in the forms of titles, nicknames, professional verbiage, or slang terms.

\section{Critical Theory}

Critical theory examines social conditions and how they create unequal power relations (Merriam \& Bierema, 2014; Merriam \& Tisdell, 2016). According to researchers, critical theory seeks to do three important things: (a) examine and critique social conditions, (b) challenge "truths" and ideologies set by dominate social groups while examining power relations created within society, and (c) emancipate marginalized people groups and eliminate oppression of these people groups (Kezar, Carducci, \& Contreras-McGavin, 2006; Merriam \& Bierema, 2014; Merriam \& Tisdell, 2016).

Merriam and Bierema (2014) stated critical minds "ask questions about social conditions" (p. 215) including asking questions regarding school culture. Based on the ideas of critical theory, critical educational leaders should constantly be thinking about the design of their buildings' school structure and culture is set up. Merriam and Tisdell (2016) asserted that "critical educational research examines the context where learning takes place, including the larger systems of society, the culture, and institutions that shape educational practice" (p. 61). Within the school setting this would include examining the culture of the school, how it came to be, and where the power and resources within the school setting lie.

\section{Leader Member Exchange Theory}

Leader-member exchange theory is an approach that sees leadership as a process, examining the interactions and the relationship between a leader and followers. The 
LMX theory challenges the assumption that leaders treat followers as a collective group and studies the differences that may exist between a leader and each follower (Lunenburg, 2010; Northouse, 2016). Research shows that "leaders often act very differently toward different subordinates, and develop contrasting kinds of relationships with them" (Lunenburg, 2010, p. 1). The first kind of relationship was considered the "in-group", and the second kind of dyadic relationship was considered the "out-group" (Lunenburg, 2010; Northouse, 2016). According to Northouse (2016), "followers become a part of the in-group or the out-group based on how well they work with the leader and how well the leader works with them (p. 138). Research shows groups are initiated by the leader's interaction with the followers, and they may be picked unconsciously based on the leader's preferences or personality. When leaders are not aware of these unconscious thoughts, decisions, and relationships, it can influence who is chosen to be a part of the "in-group" and who is chosen to be a part of the "out-group" (Lunenburg, 2010; Northouse, 2016).

\section{International Baccalaureate}

International Baccalaureate (IB) was formed in 1967 after World War II in an effort to provide quality schools and curriculum for the children on European and American diplomats, military, and international business men traveling overseas for years at a time (Mathews \& Hill, 2005).

Existing research shows a trend of urban and low performing schools adopting the IB program into their buildings to help improve academic standards (Bunnell, 2009). According to Mayer (2008), certain federal incentives and other standards set forth have "prompted struggling urban school districts across the country to introduce rigorous 
curriculum like...International Baccalaureate (IB) programs to help raise students' academic performance" (p. 202). The article states there is little evidence to justify this kind of reform to help academic achievement in students of color and low socioeconomic status (SES) (Mayer, 2008). According to one survey, $70 \%$ of the public schools in the United States who adopted IB curriculum did so to improve academic standards (Bunnell, 2009). However, there is little research that examines the effects of the implementation of IB on the school culture or any area outside of student achievement. In fact, one article even stated that "there is a surprising paucity of literature regarding the IBDP” (Bunnell, 2008, p. 411).

Limited studies have discovered that IB can have a positive impact on schools and their culture (Duarte, 2012; Mayer, 2008; McMaster, 2015) and others have discovered a negative impact on school culture (Bunnell, 2008, 2009; Drake, 2004; Duarte, 2008). Positive impacts range from improved professional practice, instructional focus on higher level thinking and learning, cultural awareness, relevance of student learning (Stillisano et. al, 2011) as well as higher GPA, increased school pride, better instructional techniques by teachers, and a better community outlook on the school (Duarte, 2012). On the other hand, some studies have stated its implementation has created a culture war (Bunnell, 2008, 2009). Drake (2004) warned of the potential for cultural dissonance, while Hill (2007) stated that "international education has often been described as elitist...a sense of exclusiveness lingers on" (p. 247).

\section{Research Design and Analysis}

Based on the ideas of organizational culture, this phenomenological case study used a critical framework (Merriam \& Bierema, 2014) and LMX Theory (Northouse, 
2016) to guide the collection of qualitative data. This study investigated the school culture of a struggling high school twenty-three years after the implementation of the International Baccalaureate Program.

\section{Setting}

Central High School was built in 1893 and is located in Springfield, Missouri, the first high school in the city. It remains the most racially and socio-economically diverse school in Springfield. The school has been nearly closed; the last attempt was in 1995, when enrollment was at a new low. School board members were considering tearing the school down or selling it to the neighboring college, but the introduction of the International Baccalaureate Program happened in 1996. This has transformed Central into one of the premiere high schools and college preparatory programs in the nation (Central High School, 2017a).

Roughly one-fourth of the student population participates in IB in some way; however, demographically, the totals for the IB program at Central are very different from the rest of the school. For the 2017-2018 school year, the IB program student demographics at Central High School were as follows: (a) 18.3\% of IB students were on free and reduced lunch, (b) $79.8 \%$ of the IB student population were White, and (c) $2 \%$ of the IB student population were Black. However, Central High School as a whole has almost $51 \%$ of students on free and reduced lunch, $70 \%$ of the total school population at Central is white, and $13 \%$ of students at Central are racially classified as black.

\section{Participants}

The participants of this case study were graduated students, as well as teachers and staff at Central High School spilt into specific groups: those who are involved in IB, 
those who are considered non-IB, and those who have been a participant in both the IB and the non-IB programs.

Teachers. All 84 teachers working in the building were potential participants and were contacted to take the online survey. This sample was both comprehensive and purposive sample (Creswell, 2016; Fink, 2013). Sampling all teachers for the survey gave the greatest chance of many responses for data saturation. The teacher sample included every subject area, grades 9-12, male and female, and varying years of experience.

Students. Student participants included 10 IB students, 10 non-IB students, and 10 students who have taken both IB and non-IB classes. These 30 students were asked to participate in the same online survey provided to the teachers at Central High School.

Choosing the 30 students to participate in the survey process is a convenient and purposive sample (Creswell, 2016; Fink, 2013). These students were recent graduates of Central High School with a graduation date of either 2016 or 2017.

\section{Data Collection Tools}

By investigating different data sources, a more complete portrait of school culture at Central High School and the role that implementation of IB had played in that school culture was gained. Utilizing several different data sources also allowed "data triangulation" and "data saturation" helping to support the case study findings (Creswell, 2014; Merriam \& Tisdell, 2016; Yin, 2014). All data collection tools such as survey items, observation guides, and artifact collection were guided by the case study approach (Creswell, 2014; Fink, 2013; Merriam \& Tisdell, 2016; Seidman, 2013; Yin, 2014). The data collection tools were developed using critical theory (Merriam \& Bierema, 2014) as 
well as LMX theory (Northouse, 2016). The "how" and "why" questions were asked as well as questions that "require an in-depth description of some social phenomenon" (Yin, 2014, p. 4).

Online Survey. Online qualitative surveys using open ended questions through Qualtrics were sent to teachers and students participating in the case study. Qualitative survey questions are located in Appendix A and B.

Artifacts and Documentation. Artifacts and school documents such as yearbooks, newspaper clippings, Twitter accounts, school newspapers and magazines were used. This also included archival data such as school demographics. The artifact tool is located in Appendix C.

Observations. Classroom observations were done in both IB and non-IB classes as well as participant observations through my own work in classrooms, hallways, meetings, lunchrooms, and sporting events. The observation guide is located in Appendix D.

\section{Data Analysis}

In this phenomenological case study, data were analyzed through constant comparison of artifacts, survey answers, and classroom observation findings. Coding, as explained by Creswell (2016), "is inductive, working from the raw data up to the codes" (p. 154). Merriam and Tisdell (2016) discussed the three phases of coding that happen in grounded theory as open, axial, and selective. Open coding was used to examine the research data looking for emerging patterns (Creswell, 2016; Merriam \& Tisdell, 2016; Yin, 2016). Once patterns were detected in the open coding, axial coding took place to make meaning of the data patterns and sort them into more meaningful categories or themes. From there, analytical coding provided interpretations of meaning and reflection 
(Merriam \& Tisdell, 2016). "Data triangulation" was created by utilizing all forms of data, surveys, artifacts, and the classroom and participant observations. This also created data saturation to support the case study findings (Creswell, 2014; Merriam \& Tisdell, 2016; Yin, 2014).

\section{Researcher Positionality and Research Ethics}

I have spent the last nine years at Central High School serving as an educator, a coach, and counselor. Benefits of being an insider in this research project included the access I had to the organization as well as to the artifact data collected for this study. Conversely, taking on the role of the participant as observer (Creswell, 2014; Merriam \& Tisdell, 2016) brought with it some barriers. In order to combat possible bias, the following safeguards were put in place. First, data triangulation with four different data sources was utilized (Creswell, 2014; Merriam \& Tisdell, 2016; Yin, 2014). Second, researcher positionality and bias were clearly defined and discussed throughout the research (Creswell, 2014; Merriam \& Tisdell, 2016). Third, an audit trail was utilized describing "how data were collected, how categories were derived, and how decisions were made throughout the inquiry" (Merriam \& Tisdell, 2016, p. 252). Fourth, a peer debriefing and expert review was used to enhance the accuracy of the account and data collected (Creswell, 2014; Merriam \& Tisdell, 2016). Lastly, using a rich, thick description as well as placing actual quotes within the study increased the validity and transferability of the research (Creswell, 2014; Merriam \& Tisdell, 2016). These safeguards increased the study's trustworthiness and reliability, as well as improved the credibility of the findings and its transferability. 


\section{Findings}

Findings from this research emerged from student demographic data, 6 classroom observations, 1 lunchroom/commons observation, 23 artifacts, 38 teacher survey responses, and 12 student survey responses. Two overarching research questions were used to drive the study: Based on student and staff perception, what is the current culture at Central High School? What is the role of the International Baccalaureate Program in that culture?

For themes emerged when analyzing data from question one: The current culture at Central High School (a) celebrates diversity, (b) honors history, (c) is superficially united, and (d) is deeply divided. Three themes emerged when analyzing data from question two: The International Baccalaureate Program at Central High School (a) attracts diversity, (b) promotes inclusion, and (c) facilitates division.

\section{Celebrates Diversity}

The current culture at Central High School celebrates its diversity. For the 20172018 school year, the demographics are as follows: (a) $50.78 \%$ of students were on free and reduced lunch, (b) $70.69 \%$ of the student population were White, (c) $12.83 \%$ of the student population were Black, (d) $7.02 \%$ of the student population were Hispanic, (e) $7.66 \%$ of the student population were Asian, (f) $.87 \%$ of the student population were Pacific Islander, (g) $.93 \%$ of the student population were Indian, and (h) $9.34 \%$ of the student population were ELL (DESE, 2017). Demographically speaking, Central High School is one the most diverse high schools in southwest Missouri. Central High School also houses middle school students in their Gifted Scholars Program, along with several IB programs. Data from surveys, observations, and artifacts, also showed that Central 
High School celebrates the diversity they have within their building. While Central may not be diverse by national standards, it is one of the most diverse high schools in Southwest Missouri, and Central High School celebrates that diversity.

Artifacts such as Central High School's yearbooks and newsletters, The Central High Times, showed many examples of celebrating diverse culture. Stories about a multitude of clubs, athletics, teachers, and students were presented in the tri-yearly issues. "Humans of Central" is a regular column in the CHTimes where different students are highlighted each time. The clubs at Central High School were also an indication of the diversity of students. Clubs range from the typical drama, band, FBLA, and math club to the more atypical groups such as bass fishing club, young republicans club, communist club, grappling club, ping pong club, and salsa club. Some clubs at Central were built specifically to help increase cultural diversity and awareness within the school. These clubs included the Four A's (African American Academic Achievers), Gender Equality Society, GSTA (gay-straight transgender alliance), Nerd Club, and Cultural Diversity Club to name a few. However, Central High School does have other activities that are different from other high schools such as a yearly diversity assembly. At this assembly (see Figure A), students from different backgrounds and cultures are allowed to perform to celebrate the diversity at Central High School.

Observations of classrooms, hallways, and the lunchroom/commons all revealed similar findings. When visiting classrooms and walking through halls, I observed students from many different walks of life. Observations during lunch time revealed the most diversity, as this was the only chance to see all students at the same time in the same place. Around the walls in the commons were flags for every country represented by 
attending students. When studied, Central High School had over 40 countries represented in the student population (see Figure B). During lunchtime, students very naturally split themselves up to sit with who they were most comfortable with, and many areas of diversity can be observed. This includes different levels of SES, race, religion, nationality, LBGTQ, IB, Non-IB, Special Education, and even "Scholars" (Central's gifted middle school program). Each of these groups seem to have their own "space" in the lunchroom. One teacher shared that Central High School seems to be a bit "tribal," meaning there are many different "tribes" within the building.

From survey data, the perception of teachers and students at Central High School was the culture is diverse, and Central High School likes to celebrate that diversity. Several teachers cited specifically working at or enjoying Central High School because of the diversity. One teacher shared, "I love Central because I get to work with a group of diverse students." Another wrote "There is both great joy and challenge in the vast diversity of our student body." One student said, "Central is a culmination of many people groups in one building." Another student shared the reason she chose to attend Central High School by saying, "Central has the most diversity and I wanted to be in a program with this diversity."

\section{Honors History}

The current culture at Central High School honors its history. In fact, much of the culture of Central High School was built around its history. It is evident staff and students at the school are not only aware of the history found throughout the building, but they also value it. In 2018, Central High School celebrated its $125^{\text {th }}$ birthday. Administration in the building helped commemorate this event by passing out stickers to 
students and staff alike to use around the building as well as having a birthday celebration within the district. The pride in Central High School's history was seen through artifacts, observations, survey data, and in how the school is promoted to the public.

Around the city, Central High School is known as being one of the oldest and most historic buildings in Springfield. Pictures, artifacts, and memorabilia from the history of Central High School and its evolution can be seen throughout the hallways. Items like a grandfather clock bought by the class of 1912 hangs on the wall, as well as old athletic gear, such as leather football helmets and old uniforms. A picture of the first school building as well as the first graduating class hung in the entryway at Central High School for all to see (see Figure C).

Other data supporting this finding of historic culture can be found in the building. One particular hallway, "The Hall of Ivy", has been painted with ivy by Central students and staff because the original school building was covered in ivy. This hallway is now another reminder of Central High School's history and is used to paint the names of retired staff and graduated students. One section shows the names of high school sweethearts from 1945 who ended up marrying. One of which is now on the school board for Springfield Public Schools. The Hall of Ivy, along with those student names, can be seen in Figure D.

Central High School is also proud of its history in the fight for civil rights. Historically, it is one of the first schools to become integrated and in 1954 opened its doors to students of color. Linda Brown, namesake to the famous civil rights case, "Brown vs. The Topeka Board of Education", was the first student of color to attend and graduate from Central High School. Her name and story are also displayed within the 
entryway at the school, along with other notable CHS graduates, such as Bob Barker (see Figure E).

Other specific areas in the building also point to the historic culture of Central High School. The auditorium is original and was used early on in Town Hall meetings for the city of Springfield in the early 1900s. It was most recently used in a Town Hall meeting for Springfield on the topic of gun violence in schools and gun laws. The gymnasium, proudly called "The Pit" is the oldest gym in the city and holds a place in many hearts. Specifically, Central High School has a room called "The Heritage Room” where artifacts from the school's history are proudly displayed. Additionally, there is a "CHS Heritage Room Digital Collection" that can be found online. According to this artifact website, "The room houses scrapbooks, pictures, newspapers, and various memorabilia that has accumulated over the decades". It shares such items as newspaper articles dating back to 1922, yearbooks as early as 1904, and issues from Central High School's newsletter, the CHTimes dating back to 1912. The school's website also gives a timeline of the school's history, as well as shows a video produced in 2014 by a local public television broadcasting network sharing the school's historic story. Graduates who have come back to work at the school often site the history of the building as being one of the biggest draws of Central High School to the general public.

\section{Superficially United}

The current culture at Central High School is superficially united. There is an evident push for unity from students and staff alike. This was noted in artifacts, observations, as well as teacher and student survey data. One teacher shared in a survey response, "Early in my career, there was not much interaction between IB and Non-IB 
students. The last 3-4 years has seen a push from the staff to try and get Non-IB students more involved and not make it exclusive to only IB students." Similarly, a recent student led hashtag movement started at Central High School. The \#OneCentral movement was used during the 2016-2017 school year by Central's Cabinet/Student Council to bring students and staff together. Central Cabinet shared this statement in an issue of the CHTimes: "In particular, one social divide has caught the attention of many students and has dominated conversation regarding \#OneCentral: The divide between IB and Non-IB students. Right now there are two groups almost competing against each other, which is a really negative environment for our school and we want there to be an equal playing field." The hashtag was used by Central High School's social media outlets as well as printed on t-shirts, stickers, and posters throughout the building. The \#OneCentral movement was met with both positive and negative responses. One student responded back to the movement with this thought: "Align your words with action and do something. Starting a hashtag won't solve problems. I haven't seen Cabinet do anything to unite us." One student shared their view on the subject by using bathroom wall graffiti to exclaim, "\#OneCentral is corrupt and will never work for Non-IB kids."

In one classroom observation the teacher gave an assignment to find unity within the building. The task was for students to walk through the school making notes of the diversity they saw. Students were given this challenge when they left the classroom: "How inclusive is Central High School? Diverse? Yes. Inclusive? Maybe not. If you walk the entire building you will see diversity, but do you see inclusiveness throughout?"

Teachers and students agreed with this line of thought as shown in their survey responses. One student shared their feelings on the topic saying, "I love the diversity that 
Central holds within the halls, but the only negative I see is that IB students are typically in leadership roles for clubs and extra-curriculars. That gives people the idea that IB students are more valuable than non IB, which isn't true at all." Teachers shared similar sentiments, one saying, "The big thing is we talk about diversity...but we do not truly have diversity - diversity is a word to use because that is the flavor of the month," and another simply said "You can't put up posters or make MYP unit plans and make us cohesive."

Artifacts that promote diversity within the building also promote unity. The celebrations of different groups of students and staff display cases, yearbook stories, and artifacts around the school speak to the desire for Central to be a unified school. This promotion comes in many forms, including the school's mission statement and the written values that it upholds. Central High School's specific mission statement reads:

The vision of Central High School is to be a Premier Educational Center providing a quality education for a diverse student population. We are committed to developing a community of learners devoted to academic excellence, good citizenship, and the celebration of diversity. We believe in providing opportunities for all students to develop lifelong skills in these areas: Academic Excellence, Global Citizenship, and Diversity.

One wall in particular was painted by a student at Central High School so more students would feel included. It has been named the "Hello Wall." On it is a picture of the globe written with the word "hello" in many languages (see Figure F). This is one of many examples of how Central has created a unified culture on the surface. 
Even with these artifacts and social media pushes, some still feel the unity is surface level. The student Cabinet at Central High School has even started a new hashtag movement in light of the reaction from \#OneCentral. In another issue of CHTimes they said, "After the controversy surrounding the \#OneCentral hashtag from last year, Cabinet has created a new hashtag: \#BulldogNation. The hashtag aims to better promote the sense of inclusiveness that \#OneCentral was attempting to create." One teacher shared this insight which gives a good picture of the unified surface of Central:

Again and again, the same students with the same friends are featured in everything. In a school as large as ours, we should always be showcasing the talents and abilities of unknown students. There is a verbal adoration of our diversity, but in school wide practice, this is not always valued. Therefore, Central's respect for diversity can come off as insincere at times.

\section{Deeply Divided}

The current culture at Central High School is deeply divided. While the evidence of a push for unity exists, the data show that Central's culture is divided. Last year, in light of the student led \#OneCentral movement, student leaders also took a poll of the student body for their perception of the divide at Central. The survey asked pointedly, "On a scale of 1-10, how divided is Central, 1 being not divided at all, and 10 being very divided." Of the 136 students that took this poll, $82 \%$ of them said Central was divided at a 4 or above, and $51 \%$ said that Central was divided at a 6 or above.

When asked what causes division at Central High School, 43 of the 136 students made specific mention to IB. Some of the student quotes from this student led survey are as follows: "The different 'cultures' of IB vs Non-IB students. I think it's something that 
we're aware of, but just sort of accept." Another stated, "IB creates an atmosphere of some students are more valuable than other students which is toxic for both sides." Still another shared simply, "It's IB, and I'm in IB. Wage differences, I wish I didn't have to say it, race. But ultimately, it's IB." One student declared simply: "The fact is that the two groups are just too different. Non-IB students don't care, and IB students don't want to feel shamed into believing that they are somehow contributing to a problem that quite frankly isn't an issue." This specific student felt the school was divided at a level 8 . However, the idea that this division was not a problem was not shared by the majority. In fact, $99 \%$ of the 136 students polled answered "yes" when asked if they would like to see a change in this division.

Based on responses from teacher and student surveys, the culture at Central High School is divided, specifically by IB. Teacher survey responses shared thoughts such as, "there is an obvious divide" and "they are divided into cliques" as well as "I believe the DP students act elitist over other students." One teacher went as far as to say that Central High School is a "clique atmosphere where if you are not in you are out. Everything is a double standard - IB and Non-IB are two different worlds." Another teacher even shared a very specific story about her classroom full of students by responding:

I made the mistake, once, of saying to my traditional LL student that 'we are all IB at Central' and I was nearly burned at the stake. There is a stark divide between the traditional track and the IB track. This divide continues to decrease as more teachers accept the responsibilities of MYP and the Career Program, but it will never fully disappear.

One particular artifact painted a very clear picture of the division happening at 
Central High School. A 2016-2017 issue of CHTimes included a story about a retiring teacher. The teacher was quoted as saying:

I love my IB kids, but they can teach themselves and don't really need me like the non-college bound kids do." A Central High School student snapped a picture of the article, posted it on Facebook, and tagged Central's IB Facebook page with the caption, "How can a teacher say that about non-IB kids, and then how can CHTimes let it get published? This is the mentality that emits from the entire IB program, and it is absolutely proven by this. Absolutely disgraceful.

Quickly a back and forth debate ensued on the public forum of Facebook (see Figure G). Several students joined in the debate surrounding the culture of IB and nonIB, sharing their thoughts and perceptions of the division of Central High School and why it stems from the IB program.

\section{IB Attracts Diversity}

International Baccalaureate at Central High School attracts diversity. The IB program brings in students from all over the city which automatically makes the school's student demographics more diverse. The mere presence of IB on Central High School campus has increased building diversity in SES levels, race, ethnicity, nationality, and academic achievement. This can be seen in student demographics, as well as test scores, and other achievement indictors. The mere presence of the IB program on Central High School campus will continue to attract diverse student populations that otherwise it would not. 


\section{IB Promotes Inclusion}

International Baccalaureate at Central High School promotes inclusion. IBO's mission and values center around rigorous academics and assessment, international mindedness, and life-long learning. The IB Mission Statement states the aim of IB is to “develop inquiring, knowledgeable and caring young people...to encourage students across the world to become active, compassionate and lifelong learners who understand that other people, with their differences, can also be right" (International Baccalaureate Organization, 2017c). The very mission of IB is to be inclusive of diverse people and thought. This can be seen through their international minded curriculum, language, and values.

\section{IB Facilitates Division}

Even with the previous two findings, International Baccalaureate at Central High School facilitates division. While IB produces many positive outcomes, data also show that IB helps to create division within the school as well, which suggest the divide is school wide and is affecting students and staff alike.

Most often students and teachers cited different rules, expectations, treatment, and resources for those who are a part of the IB program and for those who are not. This was true from both student and staff perceptions. Words such as "elitist" and "superior" appeared again and again in the data when describing the IB students and program while words such as "at-risk" and "non-college bound" were used to describe the non-IB students and non-IB classes. One student shared his perceptions of the values and beliefs at Central High School concerning the divide between IB and non-IB saying: 
IB students and non-IB will always have a divide. It is an unfortunate issue but they are too far separate to integrate well. Yes, the IB kids do kind of run the school, but often times that is because nobody else steps up to do it anyways. Such as student body and Cabinet. I don't mean to be harsh, but it's a reality.

Teachers had similar feelings, one in particular sharing that IB "is a realm where students who are in it are considered more important some-how. IB students are granted forgiveness quickly. There is an assumption of innocence that is not granted to the entire student body." Another teacher said most staff in the building "recognize the unfair attention most IB students get. Teachers who teach non-IB feel the SILENT STIGMA of not teaching IB. We don't know the lingo, we haven't had the kids in class that everyone in the building seems to know and recognize." Another alleged that as a whole, the staff "treat these students (non-IB) like lesser than. They don't feel like they have the time of day to deal with them. They call them 'those students' or the 'general population' or 'regular'. They perpetuate the gaps between the two groups." One teacher even went as far as to say this divide has caused issues between teacher relationships saying, "IB teachers seem to get more training and the ability to take students on field trips, etc. This has caused some resentment but mostly, being an IB teachers seems like you are better than non-IB teachers."

Throughout the data, many different reasons for the division between IB and nonIB in Central High School surfaced. One teacher shared, "Many times there is a different set of rules for IB students because they are generally looked upon as trustworthy and deserving of privileges," and another declared, "IB students are privileged and are able to get away with a great deal more than non-IB students." One quote from a teacher survey 
simply said, "Non-IB has the feel of working more with the general population of students, yet having the knowledge that a more elite group of students who exist on the same campus."

\section{Summary of Findings}

Similar themes continued to surface from the data. The culture at Central High School celebrates diversity, honors history, is superficially united, and is deeply divided. IB has played a role in that culture by simultaneously attracting diversity and promoting inclusion while at the same time facilitating division. The four pillars used in this research to help define culture were: a) shared values and beliefs, b) norms and rules, c) symbols and artifacts, and d) language. The values and beliefs at Central High School help create their culture. However, the unspoken value and beliefs from the student and teacher perspective is that those in IB, whether student or staff, may be valued more than those not in IB. Teachers and students alike shared these feelings.

Teachers had similar perceptions when sharing their feelings about the divide between IB and non-IB. One statement was that "[t]here is definitely an elitist type of status if you get to teach the Diploma level classes." One teacher even said, "When I first started teaching at Central, the IB teachers in my department set themselves apart as uniquely talented and more superior to the non-IB teachers."

The norms and rules would point to a similar outcome. Written rules are the same throughout the building. However, based on teacher and student perspectives, the unspoken rules and norms are not the same for those who are in IB and those who are not. The perception is those students in IB have more leinient rules, have more resources for their classes, have the better teachers, as well as are afforded training for those staff 
members. One teacher with no IB classes said, "at times it feels as if we are left out," and another shared, "teaching non-IB means your time is wasted EVERY SINGLE TIME we have training. MYP/IB/SPS/BS...it's all the same" (teacher survey).

Symbols and artifacts in the building point to a united culture at Central High School. The stories, histories, heroes, and celebrations of the building bring a rule unity that can be felt by anyone who is a part of Central High School. Symbols and artifacts point to a diverse building with many different types of students and staff, even if at times it can be superficial.

The language used at Central High School speaks to two distinct groups within the building, which automatically points to a culture of division. Throughout observations, artifact collection, and survey collection, a very specific language emerged for IB and for non-IB. Terms like "those students", "regular students", "my students", and "their students" were sprinkled throughout all the data. One teacher shared during a classroom observation that she had heard a group of her IB students talking about the non-IB students, calling them "the dirties". Based on language alone, one can see the split in the culture at the building. This language and these terms have been used for so long that they seem to have a definition built in to them. Because of the culture surrounding these terms, one automatically gets a picture of a student when they are named "IB" or "nonIB”. IB has become associated with high SES, intelligent, motivated, college bound students, while non-IB has become associated with low SES, not as intelligent, unmotivated, non-college bound students. While these are gross overgeneralizations, the student and staff perceptions support these definitions. 


\section{Discussion}

These findings can be reviewed and examined through the lens of the four cultural pillars utilized for data collection, as well as through the lens of critical theory and LMX theory. LMX theory states that leadership will tend to create an "in-group" and an "outgroup" (Northouse, 2016). Based on this theory the "in-group" and "out-group" is treated differently by leadership, has different rules, values, and expectations placed on them. Their relationships with leaders tend to be more productive as well. Whether or not there is a true "in-group" and "out-group" that exists at Central High School is not really the point. The point is, the perception from teachers and students alike is that there is most certainly an "in-group" and an "out-group" that is felt throughout the building and the main difference between these two groups is the line of IB.

This fact alone should be enough to make educational leaders pause. The goal of research within critical theory is to "critique and challenge, to transform and empower" (Merriam \& Tisdell, 2016, p. 10) by reflecting on societal assumptions and beliefs as well as studying concepts from a different viewpoint. The data that emerged from this research suggest some questions should be asked about the power structure at Central High School, both with students and staff, and how that power is being used to encourage and foster growth in the entire student population, not just one particular group of students. With the presence of a well-established "in-group" and "out-group," critical theory demands questions be asked as to how these groups were created and how they can be disbanded. Critical research aims to not only promote unity, but to also analyze power structures and how these power structures have helped to create "in-groups" and "out-groups." It also aims to disband these particular groups and the benefits and 
consequences that come with being a part of them. This is something Central High School will need to address to continue to grow in diversity and unity within its culture.

\section{Implications}

Findings reveal the culture at Central High School is deeply divided and that division is based on whether or not students and teachers are involved in the IB program. An "in-group" and an "out-group" have been created; IB is in, non-IB is out. If the current culture is allowed to continue, the following implications can be deduced. One, Central High School will continue to survive, and perhaps even grow, as a diverse and historic educational institution. Two, Central High School's cursory approach towards cultural division will perpetuate social, educational, and economic disparities.

Central High School will continue to survive, and perhaps even grow, as a diverse and historic educational institution. Findings indicate there is a strong historic tie to the building, as well as positive feelings towards the diverse student population. The diverse and historic culture of the school perpetuates its survival, just as the monumental growth and success of the IB program will perpetuate its survival. At this point, the historic culture of Central High School along with the many positive outcomes and successes of the IB program will be enough to sustain The school's survival and possibly even growth in the future.

Unless proactively addressed, Central High School's cursory approach towards cultural division will perpetuate social, educational, and economic disparities. Findings indicate the culture at Central High School is deeply divided. Students and staff perceive real disparities between IB and non-IB. This has caused resentment, feelings of being misunderstood, and feelings of division. Without intervention from leadership to address 
the cultural division that does exist at Central High School, the feelings of discord, separation, resentment, and elitism will also continue to be a part of the school culture.

\section{Recommendations for Practice}

Based on the previous implications, four recommendations are (a) acknowledge a concern to address, (b) analyze processes, policies, and positions by using an outside source, (c) continue promoting unity, and (d) make an authentic and applicable change. These will be discussed separately.

Central High School leadership should take acknowledge this area of concern as an issue that could be evaluated and discussed. The leadership team at the school needs to come to a consensus there might be unintended consequences produced by the IB program. By agreeing to look at the possibility of a culturally divided high school and acknowledging that division stems around the IB program would be a step forward. With this acknowledgement also comes the secondary responsibility to help change and fix the divide.

The leadership team also needs to analyze processes, policies, and positions that are currently in place. I suggest contacting an outside, unbiased third party to come in and evaluate the school. Central High School's mission statement speaks of offering "quality education for a diverse student population," "celebration of diversity," and "providing opportunities for all students..." (Central, 2017b). The leadership team should evaluate the IB program, its processes, policies, rules, and leadership positions that are currently in place. When evaluating, leaders can ask whether or not these separate items are helping to meet the mission statement of the school. Are the current policies for IB congruent with the mission statement? Are current positions such as the IB coordinator, MYP 
coordinator, IBCP coordinator, IB Counselor, IBCP Counselor, and other leadership positions in the program congruent with the mission statement? If these processes and positions are in place to help meet Central High School's mission statement, then the final question needs to be, why are they not working?

Central High School leadership should continue promoting unity. The push to change the school's language to "we are all IB," the diversity assembly, and movements such as \#OneCentral, and now \#BulldogNation are all good examples of this. Leadership should take a more active role in these areas.

Central High School leadership should make an authentic and applicable change to address the real and deep division that exists at Central High School. Three examples of these applicable changes are: (a) by forming a steering committee, commit to extended, on-going, and authentic communication between "IB" and "non-IB, (b) actively recruit from more diverse student populations to participate in the IB program, and (c) remove the application process for the IB program.

\section{Limitations}

As discussed previously, the author acknowledges possible bias within the research due to the insider perspective. Many safeguards were put in place to help combat this possible limitation. Secondarily, the case study design of this research limits the transferability of the findings. The author acknowledges the uniqueness of the case study, but also believes findings add to the value of the discussion around IB and school culture. No other potential conflicts exist with research or authorship of this article.

\section{Funding}

The author received no financial support for the research or authorship of this article. 


\section{References}

Alliance for Excellent Education (2009). The high cost of high school dropouts: What the nation pays for inadequate high schools. (Issue brief). Washington, DC:

Barth, R. (2002). The culture builder. Educational Leadership, 59(8), 7-11.

Bolman, L., \& Deal, T. (2013). Reframing organizations: Artistry, choice and leadership (5th ed.). San Francisco, CA: Jossey-Bass.

Bunnell, T. (2008). The global growth of the International Baccalaureate Diploma Program over the first 40 years: A critical assessment. Comparative Education, 44(4), 409-424.

Bunnell, T. (2009). The International Baccalaureate in the USA and the emerging "culture war." Discourse: Studies in the Cultural Politics of Education, 30(1), 6172.

Central High School. (2017a). About Us. Retrieved from http://central.spsk12.org/pages/Central__HS/About_Us.

Central High School. (2017b). School demographics and statistics. Retrieved from http://www.central.spsk12.org.

Connor, J. O. (2008). From international school to inner-city schools: The first principles of the International Baccalaureate Diploma Program. Teachers College Record, 110(2), 322-351.

Creswell, J. (2014). Research design: Qualitative, quantitative, and mixed methods Approaches (4th ed.). Los Angeles, CA: Sage.

Deal, T., \& Kennedy, A. (1982). Corporate cultures: The rites and rituals of corporate life. New York, NY: Addison-Wesley. 
Deal, T., \& Peterson, K. (2009). Shaping school culture: Pitfalls, paradoxes, and promises (2nd ed.). San Francisco, CA: Jossey-Bass.

Deal, T., \& Peterson, K. (2016). Shaping school culture, (3rd ed.). San Francisco, CA: Jossey-Bass.

Drake, B. (2004). International education and IB programmes: Worldwide expansion and potential cultural dissonance. Journal of Research in International Education, 3(2), 189-205.

Duarte, G. (2012). The international baccalaureate diploma program's impacting high school culture and climate. (Doctoral dissertation). Retrieved from UMI Dissertation Publishing Database. (Accession No. 3535489)

Fink, A. (2013). How to conduct surveys: A step-by-step guide (5th ed.). Los Angeles, CA: Sage.

Gruenert, S., \& Whitaker, T. (2015). School culture rewired: How to define, assess, and transform it. Alexandria, VA: ASCD.

Hill, I. (2007). Multicultural and international education: Never the twain shall meet. International Review of Education, 53(3), 245-264.

International Baccalaureate Organization. (2017a). Benefits. Retrieved from http://www.ibo.org/benefits/.

International Baccalaureate Organization. (2017b). Facts and Figures. Retrieved from http://www.ibo.org/about-the-ib/facts-and-figures/.

International Baccalaureate Organization. (2017c). Mission. Retrieved from http://www.ibo.org/about-the-ib/mission/.

International Baccalaureate Organization. (2017f). Introduction. Retrieved from 
http://www.ibo.org.

Kezar, A., Carducci, R., \& Contreras-McGavin, M. (2006). Rethinking the "L" word in higher education: The revolution of research on leadership. ASHE Higher Education Report, 31(6), 15-29.

Lunenburg, F. (2010). Leader-member exchange theory: Another perspective on the leadership process. International Journal of Management, Business, and Administration, 13(1), 1-5.

Manning, K. (2013). Organizational theory in higher education. New York, NY: Routledge Taylor and Francis Group.

Martin, J. (2002). Organizational culture: Mapping the terrain. Newbury Park, GA: Sage.

Mathews, J., \& Hill, I. (2005). Supertest: How the international baccalaureate can strengthen our schools. Chicago, IL: Open Court.

Mayer, A. (2008). Expanding opportunities for high academic achievement: An International Baccalaureate Diploma Program in an urban high school. Journal of Advanced Academics, 19(2), 202-235.

McMaster, C. (2015). "Where is ___?": Culture and the process of change. International Journal of Whole Schooling, 11(1), 16-34.

Merriam, S., \& Bierema, L. (2014). Adult learning: Linking theory and practice. San Francisco, CA: Jossey-Bass.

Merriam, S., \& Tisdell, E. (2016). Qualitative research: A guide to design and implementation. San Francisco, CA: Jossey-Bass.

Metha, J. (2015). Escaping the shadow: A nation at risk and its far-reaching influence. 
American Educator, Summer 2015, 20-26.

Missouri Department of Elementary and Secondary Education. (2017). School Data.

Retrieved from https://dese.mo.gov/school-data.

National Commission on Excellence in Education. (1983). A nation at risk: the imperative for educational reform: a report to the Nation and the Secretary of Education, United States Department of Education. Washington, D.C. Retrieved from https://www.edreform.com/wpcontent/uploads/2013/02/A_Nation_At_Risk_1983.pdf.

Northouse, P. (2016). Leadership: theory and practice. Los Angeles, CA: Sage.

Schein, E. (2005). Defining organizational culture. In J. M. Shafritz, J. S. Ott, \& Y. S. Jan (Eds.), Classics of organization theory (6th ed., pp.360-367). Boston, MA:

Wadsworth. (Reprinted from Organizational culture and leadership, 2nd ed., pp. 315, 1993, San Francisco: Jossey-Bass)

Schein, E. (2010). Organizational culture and leadership (4th ed.). San Francisco, CA: Jossey-Bass.

Schlechty, P. (1997). Inventing better schools: An action plan for educational reform. San Francisco, CA: Jossey-Bass.

Seidman, I. (2013). Interviewing as qualitative research: A guide for researchers in education and the social sciences (4th ed.). New York, NY: Teachers College Press.

Stillisano, J., Hostrup, J., Waxman, H., \& Rollins, K. (2011). Case studies of eight Texas schools implementing International Baccalaureate programs. Journal of Ethnographic and Qualitative Research, 5, 171-185. 
Wilkinson, V., \& Hayden, M. (2010). In International Baccalaureate diploma and student attitudes: As exploratory study. Journal of Research in International Education, $9(1), 85-96$.

Yin, R. (2014). Case study research: Design and methods (5th ed.) Los Angeles, CA: Sage. 
Figures
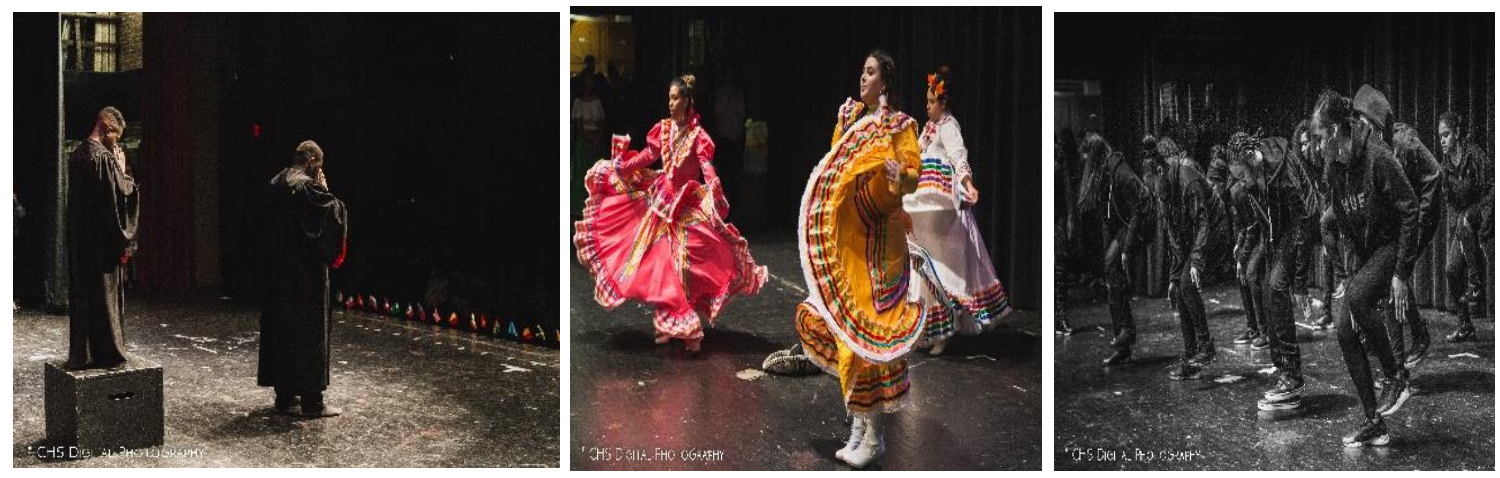

Figure A, Diversity Assembly, Central HS, 2018

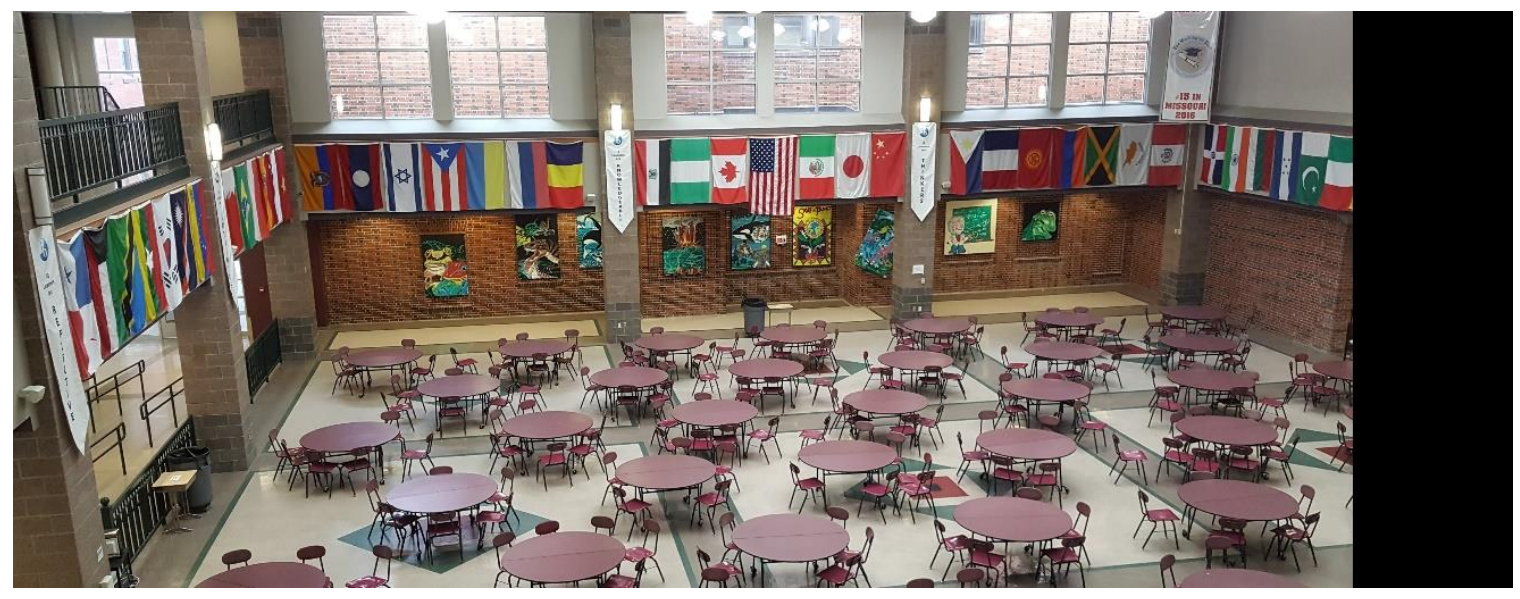

Figure B, International Flags, Central High School Commons, 2018
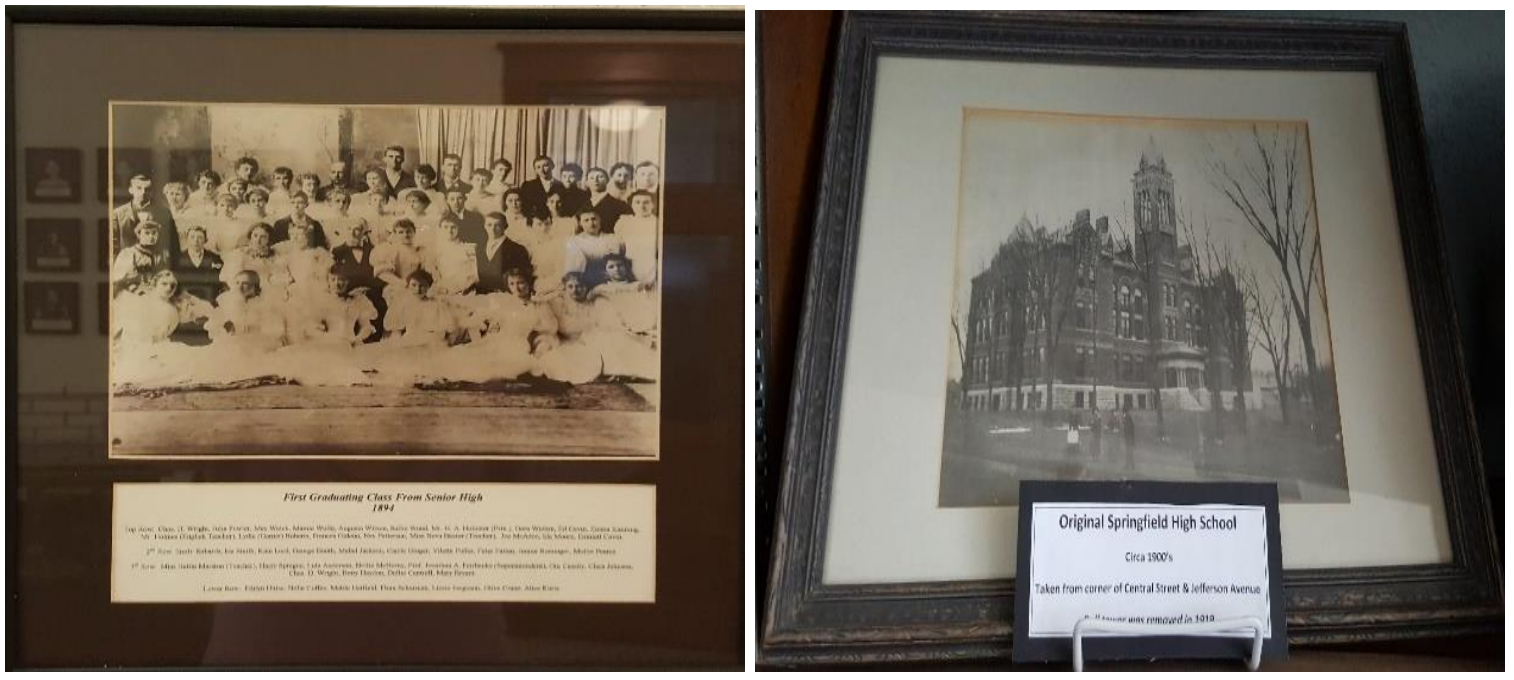

Figure C, Historic Pictures, Central High School, 2018 

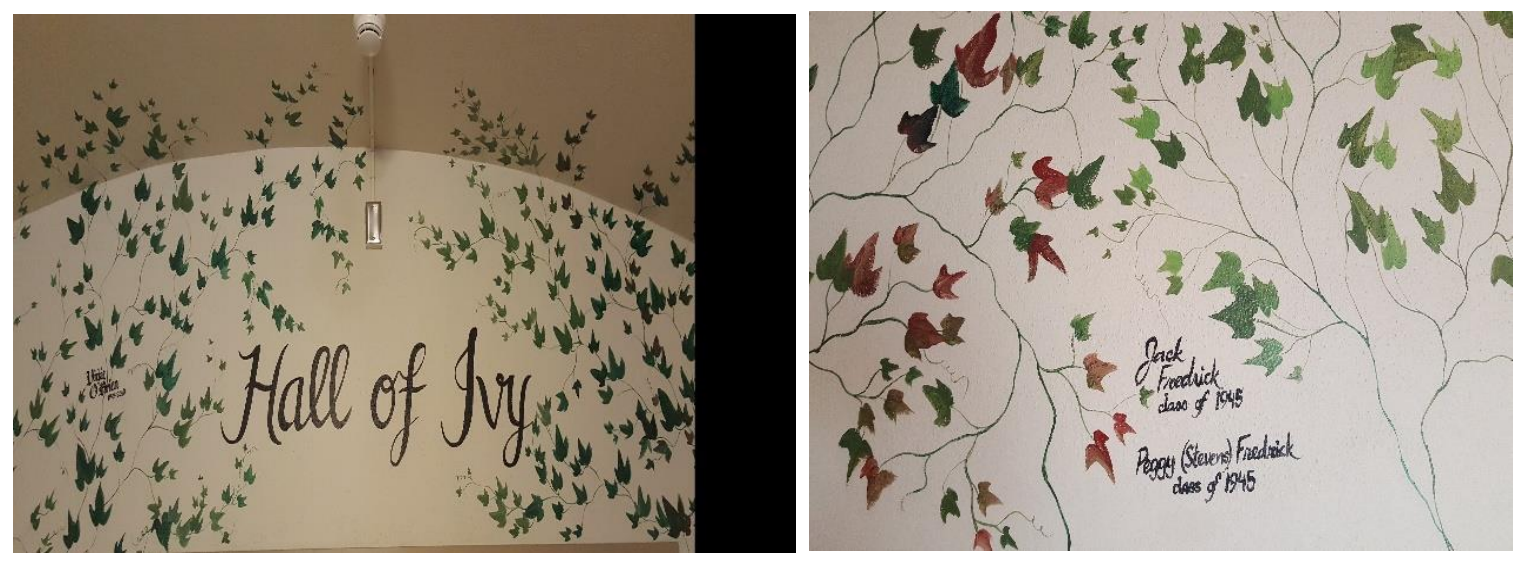

Figure D, Hall of Ivy, Central High School, 2018
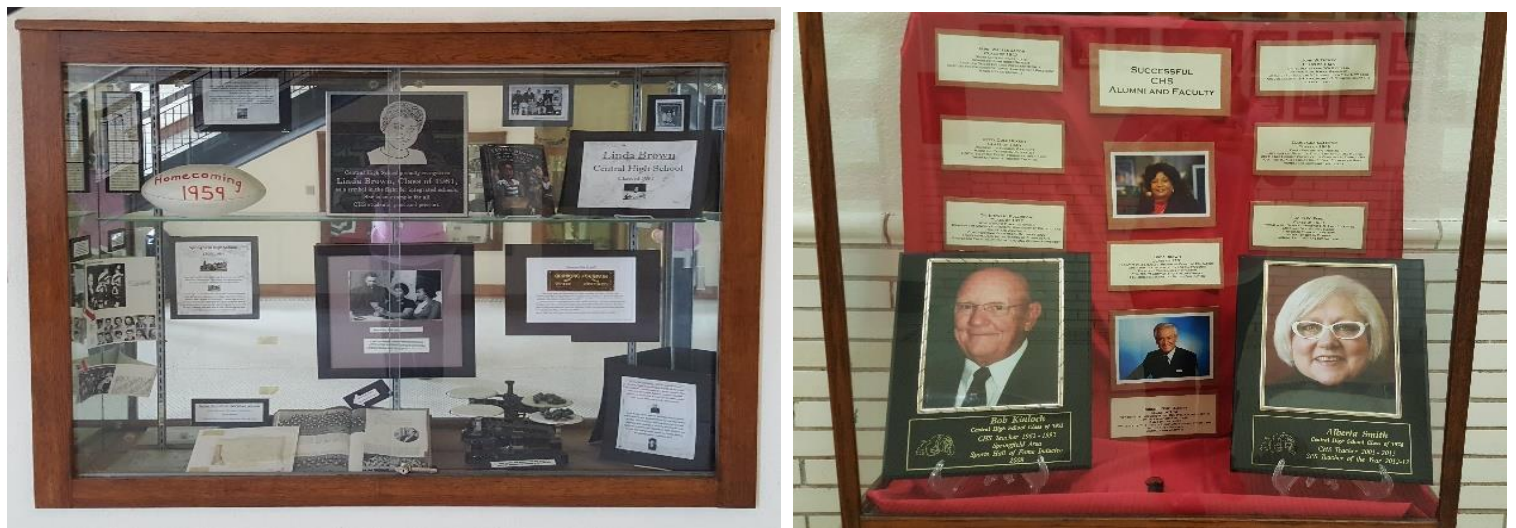

Figure E, Historic Display Cases, Notable Alumni, Central High School, 2018

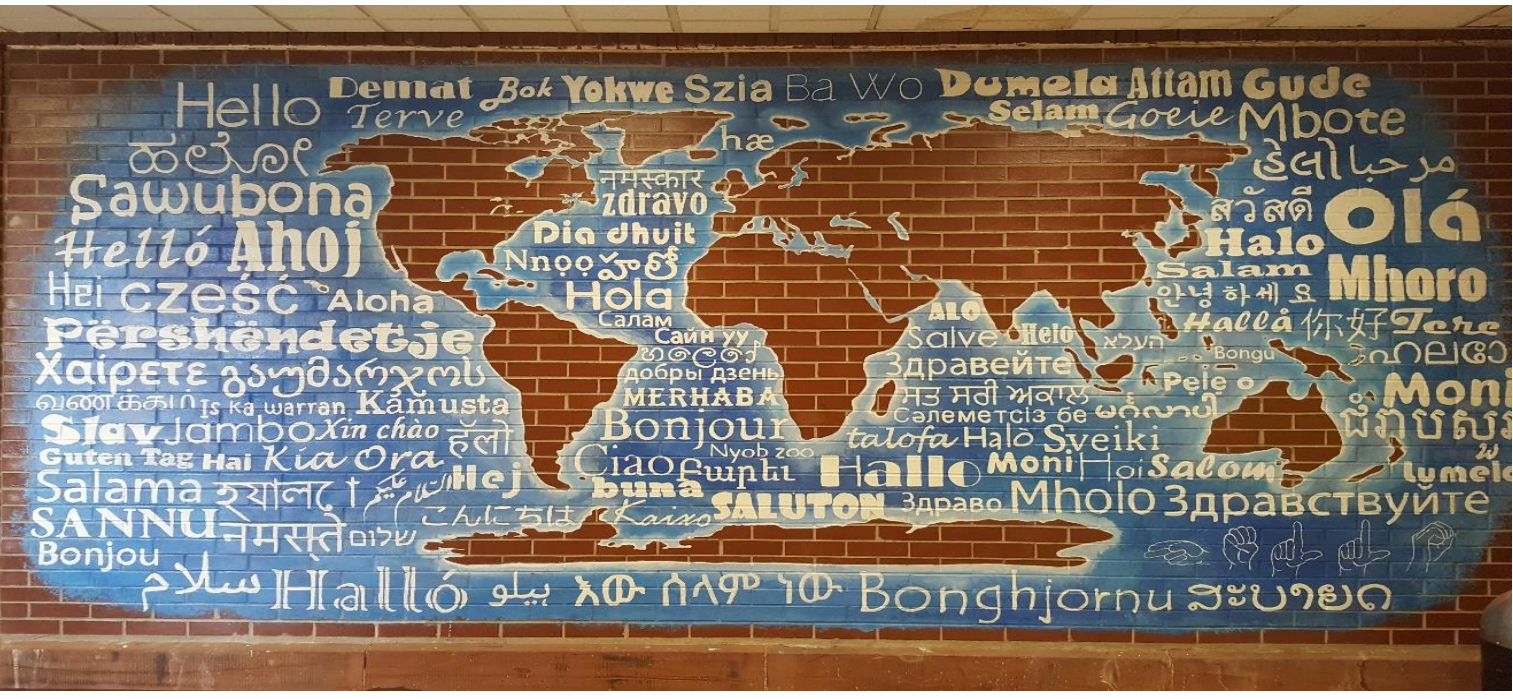

Figure F, Hello Wall, Central High School, 2018 


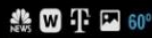

8039

Central High School IB obviously none of your students outside the IB program are going to college. Why bother with them? We're all idiots anyway, apparently. $\cdot \cdot$

Wed at 8:31 AM + Like + (1) $=14$

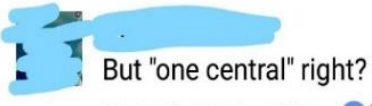

Wed at 8:45 AM · Like - (1) 8

5

That's why central is such a bad school bc none of the teachers care about the students education unless they're in IB

Wed at 9:35 AM · Like

$$
4
$$

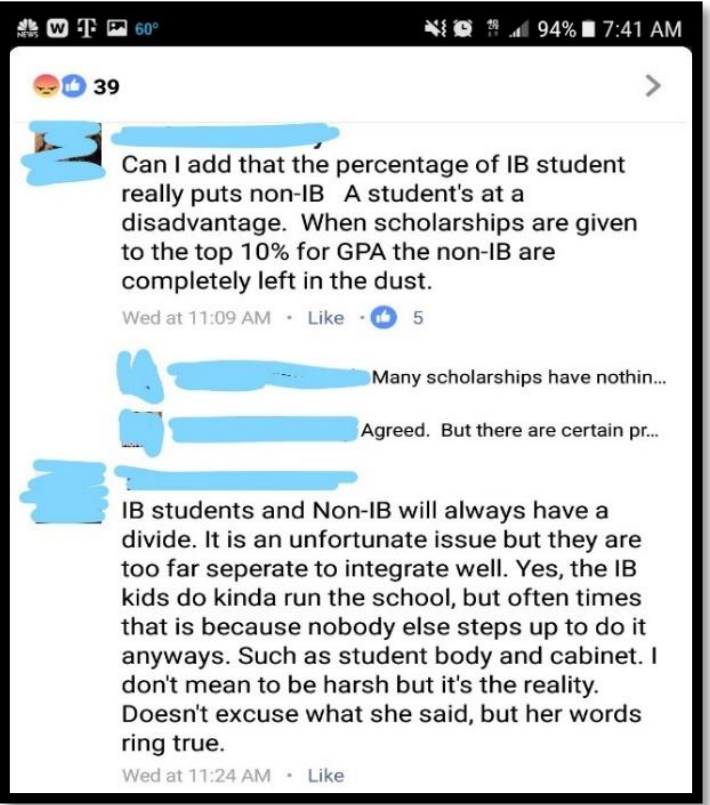

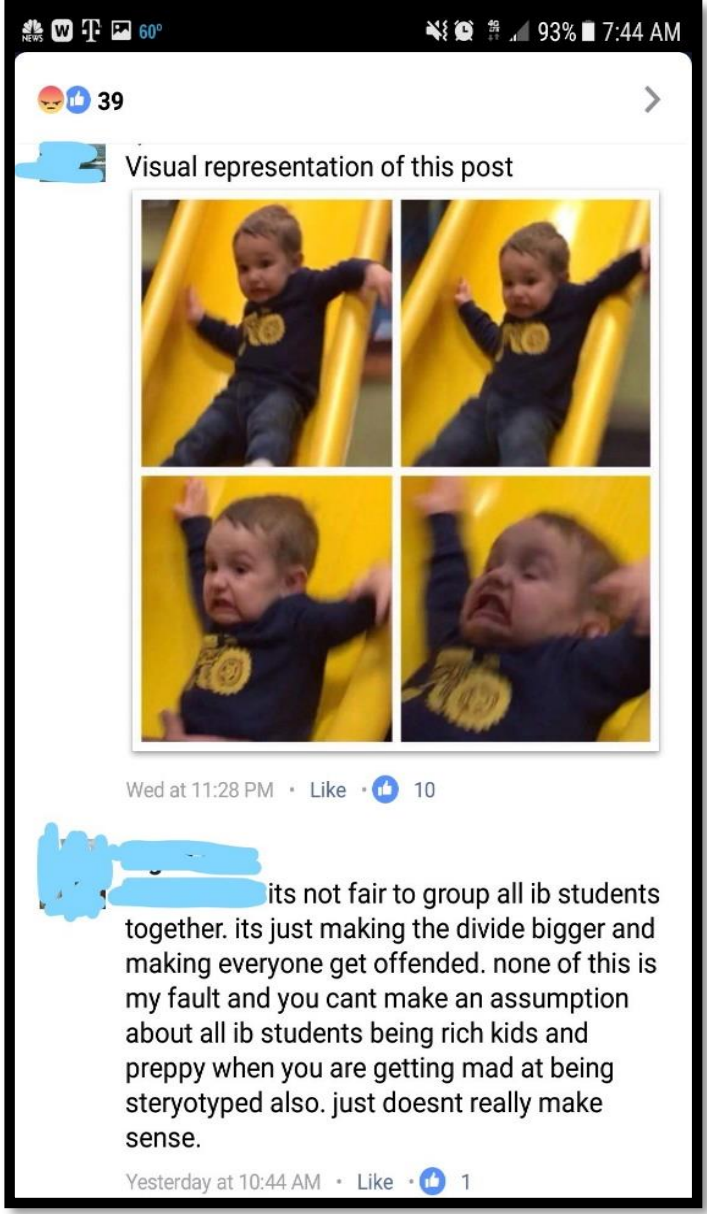

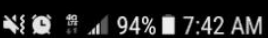

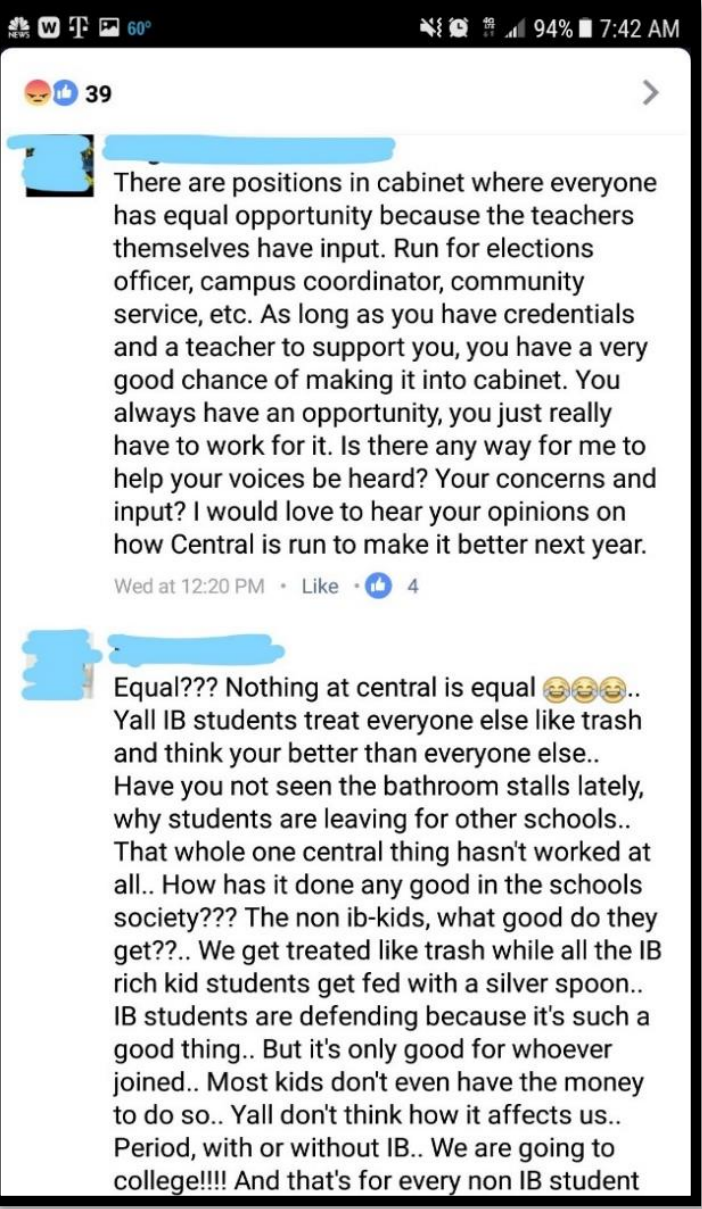

Figure G, IB vs Non-IB Facebook Discussion, Central High School, 2018 
Section Six —Scholarly Practitioner Reflection 
The dissertation process has been both challenging and fulfilling for me. My growth both as an educational leader and a scholar have been influenced not only by the dissertation process, but also through coursework, class discussion, and meeting other educational leaders and scholars. All of these items have influenced my own leadership, scholarship, and academic writing. Ultimately, I feel I have grown in both my leadership practice and as a scholarly practitioner through the dissertation writing process.

\section{Dissertation Influence on Being an Educational Leader}

While reflecting on what I was able to glean from the dissertation experience, three main ideas continued to surface. They are as follows: a) power in leadership and how it can help or harm, b) the definition of leadership and who I am as a leader, and c) who I want to become as a leader in the future.

As I was researching and writing my dissertation, the concept of power in leadership and how it is wielded was always in the back of my mind. Power can be seen in any relationship, especially the leader/follower relationship (Bolman and Deal, 2013; Northouse, 2016) Bolman and Deal (2013) stated that power is "typically viewed as a commodity that individuals or systems possess" (p. 298). Power can be positional or personal and both forms of power can bring about influence (Bolman \& Deal, 2013; Kezar, Carducci, \& Contreras-McGavin, 2006; Northouse, 2016). Throughout my dissertation writing process, I took notice of how other educational leaders in the building handled their own possession of power. I took note of how they wielded this power, whether it was in a positive or negative way, and who was affected. I made note of many decisions as an educational leader that I would choose to duplicate and many that I would not. 
One of the biggest things I learned as an educational leader throughout the dissertation process was how much good I can do with the power I hold, or contrary to that, how much damage I can do with the power I hold. I must make note of this as a leader, how my decisions as a person in power are influencing the people around me, especially the people groups that do not typically have a voice. As an educational leader in a place of power, I must be aware of those around me who may be marginalized and then make a conscious effort to bring those specific voices to the table.

From a critical perspective, leadership is about power, and therefore can be dangerous and used to marginalize other people (Kezar, Carducci, \& ContrerasMcGavin, 2006; Merriam \& Bierema, 2014). Northouse (2016) made this same kind of statement. "Because leadership involves influence and leaders often have more power than followers, they have an enormous ethical responsibility for how they affect other people" (p. 359). I must make a conscious effort daily to ask myself how my actions and decisions as a leader are influencing those around me. I have to reflect on the decisions I make as a leader, ask myself who those decisions are affecting and how. Ethically, as a leader, this is not only necessary but vital if I wish to help create a culture of learning and engagement for all people to reach their full potential.

Banaji, Bazerman, and Chugh (2015) in their article, How unethical are you, as well as Banaji and Greenwald (2013) in their book, Blind spot: Hidden biases of good people, talked continually about being self-aware, knowing where you might have some bias, and protecting yourself against those biases. Goleman (2011) stated 
that self-awareness is about "a deep understanding of one's emotions, strengths, weaknesses, needs, and drives" (p. 7). This is something I work on continually.

Secondarily to learning about leadership and power, through this process I also gained a better picture of what leadership actually is and how it looks on different people. Leadership can be about power, traits, skills, or behavior, or any combination of these things (Northouse, 2016). Goleman (2011) said leadership is about emotional intelligence. Personally, this is the theory I lean towards. In any case, depending on the researcher and theory, leadership and its application can be vastly different from one person to the next. I cannot be the same leader someone else is. My leadership style must work with my personality, and I have come to understand that my leadership style mirrors my learning style.

Both the findings from strengths quest and leadership questionnaires I took from Northouse (2016) show my two greatest leadership styles to be very directive and achievement oriented, as well as being extremely self-aware and purposeful. This has led me to think through strengths and weaknesses of my leadership style and how I might want to change, grow, and lead others in a team setting. I have noticed even within my cohort group that my achievement driven personality can sometimes cause others to pause and take a step back. People who are not as achievement or task driven find my organization and zeal to "get things done" tiring, exhausting, and at times annoying. I have had to learn to downplay some areas of my personality when working in groups or leading others so as not to cause distress and frustration.

It has become very clear to me through this process that as a leader I need to find a balance between pushing people to move forward but also allowing them time to 
think and create on their own terms, based on their personality. This is often hard for me to do, because as I move forward I generally want to bring people with me. I have come to realize through this process, not everyone is ready to move forward... and that's okay.

Lastly, I have learned through this dissertation and degree process the kind of leader that I aspire to be. Merriam and Bierema (2014) inform us that "adult educators are change agents" (p. 101). I want to be a change agent and therefore, I must work at becoming a transformative leader. Mezirow and Taylor (2009) and Merriam and Bierema (2014) speak volumes on the process of transformative leading and learning. They promote critical reflection and challenging world views. But they also bring up a question that I have been wrestling with throughout this process. "As educators, do we engage in facilitating transformative learning, regardless of where that leads?" (Merriam \& Bierema, 2014, p. 100). As a change agent, I have an ethical responsibility to take into consideration that perhaps not everyone or everything around me needs changing. I want to make things better, but am I using my idea of what "better" is to do this?

Northouse (2016) stated the transformational leader attempts to influence individual people, whole organizations, and even entire cultures. I want my life both personally and professionally to mirror this statement, but I also want to be aware of ethical components of living such a life. Holmes (2010) spoke about ways of knowing and how "certain beliefs about knowledge are valued more than others within classrooms, organizations, and cultural institutions” (p. 283). I want to be a transformational change agent who still honors all ways of knowing as meaningful and 
having value. I want to change things in a positive manner while continually asking myself the question, "Who is this change positive for?" I hope to be an educational leader who values positive change but one who also realizes that positive change and education come in many forms, so I "must pursue and achieve education by any means necessary" (Douglas \& Peck, 2013, p. 87).

I cannot speak about being a transformational leader and a person of influence without speaking about ethics. Ethics cannot just be an after-thought when considering leadership. In fact, in my opinion it is the most important consideration. According to Mihelic, Lipicnik, and Metka (2010) in their article, Ethical leadership, "ethics has a lot, if not everything to do, with leadership" (p. 31). I want to be a leader who evokes change and inspires others, but I also want to respect and value the needs, wants, goals, and hopes of those I am leading. Kannair stated, "It's not enough to espouse high standards. To live up to them - and help others do the same - requires an ethical cast of mind that lets you practice your principles consistently" (as cited in Mihelic, Lipicnik, \& Tekavcic, 2010, p. 41).

\section{Dissertation Influence on Being a Scholar}

The dissertation process had the same positive influence for my scholarship as it did for my leadership. I saw the most growth in three main areas which are as follows: a) my ability to both produce and comprehend more formal research and academic writing, b) coming to understand the deep need for policy analysis in education, and c) increasing my knowledge in scholarship increases my productivity as an educational leader. 
Pre-dissertation process, I thought I knew how to write a research paper. Actually, before this program I thought I knew how to write a research paper. The last three years proved that knowledge false. I am certain the influence of the dissertation process has improved my formal writing as well as honed my skills of reading and comprehending other's formal writing. At times it is still hard for me to get in the "mindset" of the more formal research paper, but it has become easier and easier. I am more familiar with the jargon used to produce quality research as well as speak to others more confidently about research topics. This has improved my overall confidence in the field as an educational leader and a scholar.

Because of my new-found knowledge and confidence in my own ability to be a true researcher and scholar, I also feel more comfortable analyzing and critiquing other research. Overall, this has made me a better consumer of knowledge, not just in education, but in life. I am able to look at and analyze "research" intelligently and with more confidence in areas such as politics, science, and even math. Learning more about research practices, processes, and what makes research valid and transferable has buoyed my understanding and interest in topics I have never dabbled in. Because of this, I am more well-rounded, as well as able to see other people's perspectives more clearly. This not only makes me a better leader, but an all-around better person for the world.

Secondly, this process has taught me the importance of staying up to date on current policies being acted out, presented, and voted on in education. Professionally, it is important that I continue to grow and learn in my career in the area of policy analysis. Many of the ideas used in organizational analysis can be utilized when 
analyzing policy. It is important to have a broad and complete view of policies in place so that I am able to change them if and when necessary. Looking at policies from the views of different stakeholders as well as the different groups of people certain policies will affect is always good practice.

I was never one who wanted to be involved in the politics of education. It always felt like something beyond me. I wanted to be "in the trenches" so to speak with students and teachers. I always felt like the people making policy were disconnected from what was really happening in the building and it left me disappointed and turned off to policy in education. However, learning about policy, who is making policy, and why, has helped me in my building and also inspired me to be more knowledgeable and active when it comes to decision making for education. Becoming more versed in the practice of policy analysis has helped me come to a better understanding of things that are happening within my own district and even within my own building. It is important I learn all I can and continue to grow in this area of policy analysis so I am a competent person in my field.

In the same manner, it is important that I recognize I have a responsibility to my field as an educational leader to be well versed in the practice of policy analysis because it is one of the many ways to change the culture of education for the better. Changing policy can be a long and hard road, but having the necessary information on how to analyze policies is one of the first steps to making those changes. It is also important that I become a very thoughtful and thorough decision maker. Within policy analysis in the educational system, there are decisions being made daily that affect everyone. Ethically, as an educational leader and decision maker, I must be 
prepared to make the best and most well-informed decision that I can. This means I need to equip myself both with the knowledge of policies that are running our education systems, but also the skill to analyze those policies, and the confidence in myself to perhaps make some changes to a policy one day.

Lastly, I feel this dissertation process has increased my productivity as an educational leader. I know I have spoken a bit about this in the previous section, but it has become very clear to me in this process that the very act of me becoming a better scholar has automatically made me a better leader. Allow me to explain.

I used to stay away from "research" and "politics" and "policy" not because I wasn't intelligent enough to learn about it, but because I was always so disheartened by the process and by the people who were doing it. I know that is a sweeping generalization, but I always felt those in office making decisions about education and policy that affected us as leaders in education were disconnected from the reality of what was happening inside the buildings. The reality of what we do every day with students and the reality of what our students are facing was un-relatable for them. The reality of the run down public school buildings we are working in, the reality of teachers moonlighting just to make a pay check work, the reality of the lack of resources we have to help every single student in our classroom in incomprehensible to them. Yet they make laws and rules and policies to "help us," "lead us," "fix us," without knowing us, asking us, or trying to understand us. Bottom line, it turned me off to the whole process, and I solidified myself as an educational leader and practitioner only because "those people in scholarship and policy and research don't know what they're talking about." That was three years ago. 
Fast forward to today to a person who has learned to have an appreciate and even an interest now in the scholarship and policy research in education. The reason being the dissertation process, as well as my coursework and discussion with other scholars and researchers such as yourself. What I have learned is that for me to be the best leader I can be, I also have to be the best scholar I can be. I cannot change things in education and policy if I am not willing to be in the middle of policy analysis. I cannot complain about policy if I am not willing to learn about policy and secondarily to that, learn about the research and scholarship that is driving that policy.

As an educational leader who works very hard every day to increase her knowledge and skill in leadership, I can now proudly say I am also a scholar who works hard every day to increase her knowledge and skill in scholarship and research. The ability to communicate with and relate to both groups of people, the practitioners and the scholars, will make me a more productive person in the field of education as well move me closer to being the transformational leader that I hope to be.

\section{Summary of Leadership and Scholarship}

When I look back on reflections I wrote as an undergrad student, or in my master's program, or even when I began this doctoral program three years ago, I always marvel at the change I see in myself as a researcher, practitioner, and leader. I am thankful for the change and growth. To always be improving myself both personally and professionally is something I am very intentional about. According to Maslow (1943/2005) in Theory of human motivation, we have "a desire to become more and more what one is, to become everything that one is capable of becoming" (p. 
171). That sums me up in one sentence. I love to learn and that makes me a better practitioner, educational leader, scholar, and person.

Who I am as a learner and scholar, as an educational leader, and as a change agent are all linked, all related, and ever growing. I need purpose as a scholar/learner, I use purpose as a leader, and I can create purpose as a change agent. I believe overall what this produces is an atmosphere of hope around me. I am hopeful as a learner that I can be better, I am hopeful as a leader that I can create positive experiences, and I am hopeful as a change agent that I can inspire others to hope for positive change as well. According to Helland and Winston (2005) in their article, Towards a deeper understanding of hope and leadership, "Effective leadership, it would seem, awakens hopeful thinking" (p. 45). It is my certain belief as a practitioner, scholar, and educational leader that if I can accomplish awakening hope in the world around me, then I have done my job for the day. 


\section{References}

AERA Council. (2011). American educational research association: Code of ethics. Educational Researcher, 40(3), 145-156.

Alliance for Excellent Education (2009). The high cost of high school dropouts: What the nation pays for inadequate high schools. (Issue brief). Washington, DC:

Allport, G. (1979). The nature of prejudice. Reading, MA: Addison-Wesley.

Banaji, M., Bazerman, M., \& Chugh, D. (2015). How unethical are you? In HBR's 10 must reads on making smart decisions (pp. 115-131), Boston, MA: Harvard Business Review Press. (Reprint RO312D, Originally published in December 2003)

Banaji, M., \& Greenwald, A. (2013). Blind spot: Hidden biases of good people. New York, NY: Delacorte Press.

Barth, R. (2002). The culture builder. Educational Leadership, 59(8), 7-11.

Bolman, L., \& Deal, T. (2013). Reframing organizations: Artistry, choice and leadership (5th ed.). San Francisco, CA: Jossey-Bass.

Bunnell, T. (2008). The global growth of the International Baccalaureate Diploma Program over the first 40 years: A critical assessment. Comparative Education, 44(4), 409-424.

Bunnell, T. (2009). The International Baccalaureate in the USA and the emerging “culture war." Discourse: Studies in the Cultural Politics of Education, 30(1), 6172.

Central High School. (2017a). About Us. Retrieved from http://central.spsk12.org/pages/Central__HS/About_Us. 
Central High School. (2017b). School demographics and statistics. Retrieved from http://www.central.spsk12.org.

Central High School. (2017c). Top Dogs. Retrieved from http://central.spsk12.org/pages/Central__HS/Top_Dogs.

Central High School (2017d). CHS Heritage Room Digital Collection. Retrieved from https://sites.google.com/sps.org/chsheritageroom/home?authuser=0.

Clemens, E. V., Milson, A., \& Cashwell, C. (2009). Using leader-member exchange theory to examine principal-counselor relationships to school counselors' roles, job satisfaction, and turnover intentions. Professional School Counseling, 13, 75-85.

Colquitt, J., \& George, G. (2011). Publishing in AMJ: Part 1 - Topic choice. Academy of Management Journal, 54(3), 432-435.

Connor, J. O. (2008). From international school to inner-city schools: The first principles of the International Baccalaureate Diploma Program. Teachers College Record, $110(2), 322-351$.

Cox, D. (2016). The international baccalaureate program: Access and navigation of underrepresented students. (Doctoral dissertation). Retrieved from Merlin Database. (Accession No. merlin.b11879638)

Creswell, J. (2014). Research design: Qualitative, quantitative, and mixed methods Approaches (4th ed.). Los Angeles, CA: Sage.

Da, Y., \& Liang, J. (2004). A new model for examining the leader-member exchange (LMX) theory. Human Resource Development International, 7(2), 251-264.

Dantley, M. (2009). African American educational leadership: Critical, purposive, and spiritual. In L. Foster, \& L. Tillman (Eds.), African American perspectives on 
leadership in schools: Building a culture of empowerment (pp. 39-55). Lanham, MA: Rowman and Littlefield Education.

Deal, T., \& Kennedy, A. (1982). Corporate cultures: The rites and rituals of corporate life. New York, NY: Addison-Wesley.

Deal, T., \& Peterson, K. (2009). Shaping school culture: Pitfalls, paradoxes, and promises (2nd ed.). San Francisco, CA: Jossey-Bass.

Deal, T., \& Peterson, K. (2016). Shaping school culture, (3rd ed.). San Francisco, CA: Jossey-Bass.

Drake, B. (2004). International education and IB programmes: Worldwide expansion and potential cultural dissonance. Journal of Research in International Education, 3(2), 189-205.

Duarte, G. (2012). The international baccalaureate diploma program's impacting high school culture and climate. (Doctoral dissertation). Retrieved from UMI Dissertation Publishing Database. (Accession No. 3535489)

Fink, A. (2013). How to conduct surveys: A step-by-step guide (5th ed.). Los Angeles, CA: Sage.

French, J., \& Raven, B. (1959). The bases of social power. In Cartwright, \& Darwin (Eds.), Studies in social power (pp. 150-167). Ann Arbor, MI: Research Center for Group Dynamics, Institute for Social Research, University of Michigan.

Gruenert, S., \& Whitaker, T. (2015). School culture rewired: How to define, assess, and transform it. Alexandria, VA: ASCD.

Habegger, S. (2008). The principal's role in successful schools: Creating a positive school culture. Principal, September/October, 42-46. 
Hernandez, F., \& McKenzie, K. (2010). Resisting social justice in leadership preparation programs: Mechanisms that subvert. Journal of Research on Leadership Education, 5(3.2), 48-68.

Hill, I. (2007). Multicultural and international education: Never the twain shall meet. International Review of Education, 53(3), 245-264.

Horkheimer, M. (1972). Critical theory. New York, NY: Seabury Press.

Horner, J., \& Minifie, F. (2011). Research ethics I: Responsible conduct of research (RCR) - historical and contemporary issues pertaining to human and animal experimentation. Journal of Speech, Language, and Hearing Research, 54, 303319.

International Baccalaureate Organization. (2017a). Benefits. Retrieved from http://www.ibo.org/benefits/.

International Baccalaureate Organization. (2017b). Facts and Figures. Retrieved from http://www.ibo.org/about-the-ib/facts-and-figures/.

International Baccalaureate Organization. (2017c). Mission. Retrieved from http://www.ibo.org/about-the-ib/mission/.

International Baccalaureate Organization. (2017d). What is an IB Education? Retrieved from http://www.ibo.org/globalassets/digital-tookit/brochures/what-is-an-ibeducation-en.pdf.

International Baccalaureate Organization. (2017e). Learner Profile. Retrieved from http://www.ibo.org.

International Baccalaureate Organization. (2017f). Introduction. Retrieved from http://www.ibo.org. 
International Baccalaureate Organization. (2017g). Programs. Retrieved from http://www.ibo.org.

Johnson, A. G. (2006). Privilege, power, and difference. Boston, MA: McGraw-Hill.

Kezar, A., Carducci, R., \& Contreras-McGavin, M. (2006). Rethinking the "L" word in higher education: The revolution of research on leadership. ASHE Higher Education Report, 31(6), 15-29.

Lunenburg, F. (2010). Leader-member exchange theory: Another perspective on the leadership process. International Journal of Management, Business, and Administration, 13(1), 1-5.

Madsen, J., \& Mabokela, R. (2014). Leadership challenges in addressing changing demographics in schools. NASSP Bulletin, 98(1), 75-96.

Manning, K. (2013). Organizational theory in higher education. New York, NY: Routledge Taylor and Francis Group.

Martin, J. (2002). Organizational culture: Mapping the terrain. Newbury Park, GA: Sage.

Mathews, J., \& Hill, I. (2005). Supertest: How the international baccalaureate can strengthen our schools. Chicago, IL: Open Court.

Mauro, T. (2007). Leader-member exchange theory in in administrator and educator perceptions of the collaborative nature of the school environment related to special educator retention. (Doctoral dissertation). Retrieved from UMI Dissertation Publishing Database. (Accession No. 3290750).

Mayer, A. (2008). Expanding opportunities for high academic achievement: An 
International Baccalaureate Diploma Program in an urban high school. Journal of Advanced Academics, 19(2), 202-235.

McMaster, C. (2015). "Where is ?": Culture and the process of change. International Journal of Whole Schooling, 11(1), 16-34.

Merriam, S., \& Bierema, L. (2014). Adult learning: Linking theory and practice. San Francisco, CA: Jossey-Bass.

Merriam, S., \& Tisdell, E. (2016). Qualitative research: A guide to design and implementation. San Francisco, CA: Jossey-Bass.

Metha, J. (2015). Escaping the shadow: A nation at risk and its far-reaching influence. American Educator, Summer 2015, 20-26.

Missouri Department of Elementary and Secondary Education. (2017). School Data. Retrieved from https://dese.mo.gov/school-data.

Mosley, C., Broyles, T., \& Kaufmann, E. (2014). Leader-member exchange, cognitive style, and student achievement. Journal of Leadership Education, 13(13), 50-69. National Commission on Excellence in Education. (1983). A nation at risk: the imperative for educational reform: a report to the Nation and the Secretary of Education, United States Department of Education. Washington, D.C. Retrieved from https://www.edreform.com/wpcontent/uploads/2013/02/A_Nation_At_Risk_1983.pdf.

Northouse, P. (2016). Leadership: theory and practice. Los Angeles, CA: Sage.

Parker, M. (2000). Organizational culture and identity: unity and division at work. Thousand Oaks, CA: Sage.

Power, R. (2013). Leader-member exchange theory in higher and distance education. 
The International Review of Research in Open and Distance Learning, 14(4), 277283.

Rogoff, B. (2003). The cultural nature of human developments. New York, NY:

Oxford.

Schein, E. (2005). Defining organizational culture. In J. M. Shafritz, J. S. Ott, \& Y. S. Jan (Eds.), Classics of organization theory (6th ed., pp.360-367). Boston, MA:

Wadsworth. (Reprinted from Organizational culture and leadership, 2nd ed., pp. 3-

15, 1993, San Francisco: Jossey-Bass)

Schein, E. (2010). Organizational culture and leadership (4th ed.). San Francisco, CA: Jossey-Bass.

Schlechty, P. (1997). Inventing better schools: An action plan for educational reform. San Francisco, CA: Jossey-Bass.

Seidman, I. (2013). Interviewing as qualitative research: A guide for researchers in education and the social sciences (4th ed.). New York, NY: Teachers College Press.

Selznick, P. (2005). Foundations of the theory of organization. In J. M. Shafritz, J. S. Ott, \& Y. S. Jan (Eds.), Classics of organization theory (6th ed., pp.125-133). Boston, MA: Wadsworth. (Reprinted from Organizational culture and leadership, 2nd ed., pp. 3-15, 1993, San Francisco: Jossey-Bass)

Stillisano, J., Hostrup, J., Waxman, H., \& Rollins, K. (2011). Case studies of eight Texas schools implementing International Baccalaureate programs. Journal of Ethnographic and Qualitative Research, 5, 171-185.

Theoharis, G. (2008). Woven in deeply: Identity and leadership of urban social justice 
principals. Education and Urban Society, 41(3), 3-25.

Waller, W. (1932). The sociology of teaching. New York, NY: Wiley.

Wilkinson, V., \& Hayden, M. (2010). In International Baccalaureate diploma and student attitudes: As exploratory study. Journal of Research in International Education, 9(1), 85-96.

Yin, R. (2014). Case study research: Design and methods (5th ed.) Los Angeles, CA: Sage. 
Appendix A - Teacher Survey

\section{Recruitment Script Initial Email/Teacher Informed Consent}

Hello Teachers! My name is Callie Newton-Woods, and I am a counselor here at Central High School. I am currently completing my dissertation as the last piece of my doctoral degree. I am emailing to invite you to participate in a survey regarding this research. My study investigates the culture at Central High School both inside and outside of the IB Program through the perception of teachers and students. You have a unique perspective, and I would like to understand the experiences you have had as a teacher here at Central High School and your perception of the culture.

The survey is online and will take you approximately 10 minutes to complete. You will receive the survey on $2 / 20 / 18$ and it will close at $3 / 2 / 18$. I will send a reminder email on 2/28/18 regarding the availability of the survey.

The following are more specific details about the survey and study.

\section{Invitation to Participate}

You are invited to participate in a qualitative case study investigating the secondary school culture around teachers and students inside and outside of the International Baccalaureate Program at Central High School. Your participation in this study is voluntary. You may choose to not participate or you may withdraw from participation at any time. Additionally, you may choose to not answer all of the survey questions.

Participation in the interview may cause participants to reflect on themselves and their experience as a teacher at Central High School, and as a result, it is possible that 
participants could experience varying degrees of emotional discomfort. The researcher will make every effort to minimize any such discomfort. In addition, participants may receive benefits from completing the interview, such as, learning more about themselves and the culture at Central High School.

\section{Research Uses}

The data collected for this study will be utilized by the researcher to complete the dissertation requirements for a Doctorate of Education in Educational Leadership from the University of Missouri. Participants may request to view the results by contacting the researcher (in person or 417-880-0085 or callie.ann.newton@ gmail.com).

\section{Costs/Payments}

There are no costs or payments for your voluntary participation in this study.

\section{Participant Confidentiality}

Your identity and personal information is strictly confidential, unless law requires disclosure. Survey answers, along with the compiled results of the study, will be kept on a password-protected computer. Participant responses may be quoted in the results, but no teacher identifiers will be included. The results shared in the researcher's dissertation will not include teacher names or specific identifiers.

\section{Contact Information}

You may ask the researcher any questions you have regarding this study prior to consenting to participate, during the survey, or after the survey is complete. If you wish to withdraw from this study, you may do so at any time. Please direct your questions or request to withdraw to Callie Newton-Woods at callie.ann.newton@gmail.com or 417-880-0085. 
This project has been reviewed by the University of Missouri's Institutional Review Board and by Springfield Public Schools Review Board for research and research-related activities involving human subjects. If you have questions regarding this research or the review process, please call the University of Missouri's Office of Research at 573-882-3181or Springfield Public Schools Contact, Jill Palmer at jpalmer325@spsmail.org.

Observations from responses to an online questionnaire will be used in this qualitative study "A case study - The tale of two schools - Investigating the secondary school culture around teachers and students inside and outside of the International Baccalaureate Program. The resulting dissertation will be read by Dr. Cindy MacGregor, with a formal presentation and executive summary also available to the dissertation committee and kept on record for the compliance of dissertations for the University of Missouri-Columbia.

If you would like to continue voluntarily to take part in the survey, please click the link below: (link to survey inserted in email) 


\section{Survey Questions for Teachers}

The purpose of this survey is to gain information about teacher perceptions of the influence of International Baccalaureate on school culture. The survey should take 10-15 minutes. You will receive no direct benefits from participating in this research study; however, your responses will help me gain information on this subject. The online survey does not collect identifying information such as your name or email address, which means all answers are anonymous. All information collected will be used for the purpose of completing my doctoral dissertation through the University of Missouri Columbia and will be kept confidential. If you have questions, please contact Callie Newton-Woods at callie.ann.newton@gmail.com.

By clicking the "I Agree" button, you are giving your consent to participate in this survey. I hereby consent to my information, organization's name, and my direct quotations be utilized in this academic paper. Please click "I agree" if you have read the above information, you voluntarily agree to participate, and you are 18 years or older. Introductory Questions

1. How many years have you been working in an educational setting?

- $0-5$ years

- 6-10 years

- 11-15 years

- 16-20 years

- Over 20 years

2. How many years have you taught at Central High School?

- $0-5$ years

- 6-10 years

- 11-15 years

- 16-20 years

- Over 20 years 
3. I am a

- Male

- Female

- Other

4. Which classes do you teach?

- IB classes (this includes pre-IB honors classes)

- Non-IB classes

- Both IB and non-IB classes

Open Ended Questions

5. Describe what it is like to be an IB Teacher or Non-IB teacher at Central High

School?

6. Why did you choose to be an IB teacher or Non-IB teacher at Central High School?

7. Describe how teachers act toward IB-students.

8. Describe how teachers act towards non-IB students.

9. Describe the interaction between IB students and non-IB students.

10. Describe the interaction between IB teachers and non-IB teachers.

11. Describe how school leaders act towards IB students.

12. Describe how school leaders act towards non-IB students.

13. Describe how school leaders act toward IB teachers.

14. Describe how school leaders act towards non-IB teachers.

15. Is there anything else you would like to share about your experience at Central HS? 


\section{Appendix B - Student Survey}

\section{Recruitment Script Initial Email/Student Informed Consent}

Hello Central Grads! My name is Callie Newton-Woods, and I am a counselor at Central High School. I am currently completing my dissertation as the last piece of my doctoral degree. I am emailing to invite you to participate in a survey regarding this research. My study investigates the culture at Central High School both inside and outside of the IB Program through the perception of teachers and students. You have a unique perspective, and I would like to understand the experiences you have had as a student here at Central High School and your perception of the culture.

The survey is online and will take you approximately 10 minutes to complete. You will receive the survey on 3/1/18 and it will close at 3/9/18. I will send a reminder email on 3/6/18 regarding the availability of the survey.

The following are more specific details about the survey and study.

\section{Invitation to Participate}

You are invited to participate in a qualitative case study investigating the secondary school culture around teachers and students inside and outside of the International Baccalaureate Program at Central High School. Your participation in this study is voluntary. You may choose to not participate or you may withdraw from participation at any time. Additionally, you may choose to not answer all of the survey questions.

Participation in the interview may cause participants to reflect on themselves and their experience as a student at Central High School, and as a result, it is possible that 
participants could experience varying degrees of emotional discomfort. The researcher will make every effort to minimize any such discomfort. In addition, participants may receive benefits from completing the interview, such as, learning more about themselves and the culture at Central High School.

\section{Research Uses}

The data collected for this study will be utilized by the researcher to complete the dissertation requirements for a Doctorate of Education in Educational Leadership from the University of Missouri. Participants may request to view the results by contacting the researcher (in person or 417-880-0085 or callie.ann.newton@ gmail.com).

\section{Costs/Payments}

There are no costs or payments for your voluntary participation in this study.

\section{Participant Confidentiality}

Your identity and personal information is strictly confidential, unless law requires disclosure. Survey answers, along with the compiled results of the study, will be kept on a password-protected computer. Participant responses may be quoted in the results, but no teacher identifiers will be included. The results shared in the researcher's dissertation will not include teacher names or specific identifiers.

\section{Contact Information}

You may ask the researcher any questions you have regarding this study prior to consenting to participate, during the survey, or after the survey is complete. If you wish to withdraw from this study, you may do so at any time. Please direct your questions or request to withdraw to Callie Newton-Woods at callie.ann.newton@gmail.com or 417-880-0085. 
This project has been reviewed by the University of Missouri's Institutional Review Board and by Springfield Public Schools Review Board for research and research-related activities involving human subjects. If you have questions regarding this research or the review process, please call the University of Missouri's Office of Research at 573-882-3181or Springfield Public Schools Contact, Jill Palmer at jpalmer325@spsmail.org.

Observations from responses to an online questionnaire will be used in this qualitative study "A case study - The tale of two schools - Investigating the secondary school culture around teachers and students inside and outside of the International Baccalaureate Program. The resulting dissertation will be read by Dr. Cindy MacGregor, with a formal presentation and executive summary also available to the dissertation committee and kept on record for the compliance of dissertations for the University of Missouri-Columbia.

If you would like to continue voluntarily to take part in the survey, please click the link below: (link to survey inserted in email) 


\section{Survey Questions for Graduated Students}

The purpose of this survey is to gain information about student perceptions of the influence of International Baccalaureate on school culture. The survey should take 10-15 minutes. You will receive no direct benefits from participating in this research study, however your responses will help me gain information on this subject. The online survey does not collect identifying information such as your name or email address, which means all answers are anonymous. All information collected will be used for the purpose of completing my doctoral dissertation through the University of Missouri Columbia and will be kept confidential. If you have questions please contact, Callie Newton-Woods at callie.ann.newton@gmail.com.

By clicking the "I Agree" button, you are giving your consent to participate in this survey. Please click "I agree" if you have read the above information, you voluntarily agree to participate, and you are 18 years or older.

Introductory Questions

1. I am a

- Male

- Female

- Other

2. Which classes did you take at Central High School?

- IB classes (Full Diploma Student)

- Non-IB classes (No IB classes)

- Both IB and non-IB classes (Certificate Student)

Open Ended Questions

3. Describe what it is like to be an IB student, or Non-IB student at Central High School?

4. Why did you choose to be an IB student or Non-IB student at Central High School? 
5. Describe how teachers act toward IB-students.

6. Describe how teachers act toward non-IB students.

7. Describe the interaction between IB students and non-IB students.

8. Describe the interaction between IB teachers and non-IB teachers.

9. Describe how school leaders act towards IB students.

10. Describe how school leaders act towards non-IB students.

11. Describe how school leaders act toward IB teachers.

12. Describe how school leaders act towards non-IB teachers.

13. Is there anything else you would like to share about your experience at Central HS? 
Appendix C

\section{Artifact Collection Tool}

Take notes according to these categories

\begin{tabular}{|c|c|}
\hline What is the artifact? From where? & Was it IB, non IB, or both? \\
\hline $\begin{array}{l}\text { Language used } \\
\text { - Habits, thinking, mental models } \\
\text { - } \quad \text { Linguistic paradigms }\end{array}$ & $\begin{array}{l}\text { Norms and Rules noticed } \\
\text { - The way we do things around } \\
\text { here } \\
\text { - Implicit, unwritten rules }\end{array}$ \\
\hline $\begin{array}{l}\text { Symbols and artifacts seen } \\
\text { - Rituals, celebrations, history, } \\
\text { tradition } \\
\text { - Tangible or intangible, stories }\end{array}$ & $\begin{array}{l}\text { Values and Beliefs communicated } \\
\text { - Articulate and announced } \\
\text { principles } \\
\text { - Shared meanings }\end{array}$ \\
\hline $\begin{array}{l}\text { Things I see/hear - actions/dialogue } \\
\text { - Culture bearers, priests, } \\
\text { storytellers } \\
\text { - Conflicts or consensus }\end{array}$ & $\begin{array}{l}\text { Connecting dots/Underlying assumptions } \\
\text { Any research to tie to? } \\
\text { - Climate, heroes, humor }\end{array}$ \\
\hline $\begin{array}{l}\text { LMX Theory - IN Group } \\
\text { - Who is in the "in-group" } \\
\text { - What similarities, differences do I } \\
\text { see? }\end{array}$ & $\begin{array}{l}\text { LMX Theory - Out Group } \\
\text { - Who is in the "out-group" } \\
\text { - What similarities/differences do I } \\
\text { see? }\end{array}$ \\
\hline
\end{tabular}


Appendix D

\section{Observation Guide}

\section{Observation Guide - take notes according to these categories}

\begin{tabular}{|c|c|}
\hline $\begin{array}{l}\text { Where did the observation take place } \\
\text { and who was present? }\end{array}$ & What was observer's role? \\
\hline $\begin{array}{l}\text { Language used } \\
\text { - Habits, thinking, mental models } \\
\text { - Linguistic paradigms }\end{array}$ & $\begin{array}{l}\text { Norms and Rules noticed } \\
\text { - The way we do things around } \\
\text { here } \\
\text { - Implicit, unwritten rules }\end{array}$ \\
\hline $\begin{array}{l}\text { Symbols and artifacts seen } \\
\text { - Rituals, celebrations, history, } \\
\text { tradition } \\
\text { - Tangible or intangible, stories }\end{array}$ & $\begin{array}{l}\text { Values and Beliefs communicated } \\
\text { - Articulate and announced } \\
\text { principles } \\
\text { - Shared meanings }\end{array}$ \\
\hline $\begin{array}{l}\text { Things I see/hear - actions/dialogue } \\
\text { - Culture bearers, priests, } \\
\text { storytellers } \\
\text { - Conflicts or consensus }\end{array}$ & $\begin{array}{l}\text { Connecting the dots... } \\
\text { - } \quad \text { Any research to tie to? } \\
\text { - } \quad \text { Climate, heroes, humor }\end{array}$ \\
\hline $\begin{array}{l}\text { LMX Theory - IN Group } \\
\text { - Who is in the "in-group" } \\
\text { - What similarities, differences do I } \\
\text { see? }\end{array}$ & $\begin{array}{l}\text { LMX Theory - Out Group } \\
\text { - Who is in the "out-group" } \\
\text { - What similarities/differences do I } \\
\text { see? }\end{array}$ \\
\hline
\end{tabular}

\section{Observation Guide Continued}

Draw a sketch of the room and its surroundings, including desks, teachers, students, symbols, artifacts, other players, etc. 
VITA

Callie Newton-Woods graduated from Republic High School in 1999 and has continued to grow both personally and professionally since that time. She played collegiate basketball at Drury University in Springfield, Missouri where she earned her undergraduate degree in 2003, majoring in Education and Biology. After graduation, she immediately became the graduate assistant coach for the Drury Lady Panther basketball team, and subsequently earned her master's degree as well in 2003 in education.

It was after this time at Drury that Newton-Woods began her professional educational and coaching career. She has spent the last 13 years coaching, teaching, and counseling in public high schools and universities. Most recently Callie has spent the last nine years at Central High School in Springfield Missouri where she has served as a high school counselor. She will complete her EdD in May of 2018 and continue to grow in both her scholarship and educational leadership so she may continue to serve student populations when and where she can. Callie is currently pursuing her LPC licensure, teaching adjunct classes at areas colleges, and looking forward to the next step as an educational leader. 